\title{
Subjective Social Mobility and Health in Germany*
}

\author{
Patrick Präg
}

Alexi Gugushvili

January 18, 2022

\begin{abstract}
One's current socioeconomic position is intimately tied to one's health status. Further, childhood living conditions also exert lasting effects on the health of adults. However, studies on changes in one's socioeconomic position over the life course rarely find important effects of social mobility for individual health and wellbeing. Such studies always draw on objective measures of social mobility and do not consider subjective appraisals of social mobility by individuals themselves. Using cross-sectional, representative German survey data, we explore the question as to how subjective perceptions as opposed to objective accounts of occupational status mobility affect five self-reported health and wellbeing outcomes differentially. We show that objective
\end{abstract}

${ }^{*}$ This manuscript was published in 2021 in European Societies 23(4), pp. 464-486, doi: 10.1080/14616696.2021.1887916. The data analyzed in this study are publicly available (Gesis, 2013) and a replication package can be found on-line (Präg and Gugushvili, 2021).

We thank the anonymous reviewers and the editor for guidance, Lindsay Richards and Yizhang Zhao for comments on a previous draft, and Étienne Ollion and François Bonnet for help.

Patrick Präg is an assistant professor in quantitative sociology at CREST/ENSAE Paris. He's interested in intergenerational transmission and social mobility as well as health and wellbeing. Alexi Gugushvili is an associate professor at the University of Oslo. His core research interests lie in the fields of social stratification and mobility, public opinion 
and subjective accounts of social mobility overlap, yet this association is far from perfect. Further, there are relatively small associations between objective and subjective mobility accounts and health outcomes. Associations between subjective mobility perceptions and health outcomes are intriguingly independent of objective social mobility trajectories. Mismatches between objective and subjective mobility are also correlated with some health outcomes. We discuss implications of our finding that social mobility is associated with those aspects of health which are more closely related to psychological wellbeing rather than physical health.

\section{Introduction}

Intergenerational social mobility, the trajectories that individuals and families follow from one social position to the other over the life course, is an important policy concern among many European policy makers (Eurofound, 2017). Upon taking office in 2005, German chancellor Angela Merkel noted in her first government policy statement that social origins must not determine the future of young people, a statement she repeated in her most recent government policy statement from 2018. What policy makers appear to be considering rarely, however, are the consequences of social mobility for individual lives. This study explores how far intergenerational subjective vs. objective social mobility affect health and wellbeing - a largely overlooked area of research. It is worth mentioning upfront that we use the term 'subjective' as a shorthand to mean 'as perceived and reported by the participant' and the term 'objective' to mean 'assessed according to the conventions of social stratification research.'

Over their life courses, many individuals experience a change from their childhood socio-economic environment in the form of upward or downward intergenerational mobility (Bukodi and Paskov, 2020; Grätz et al., 2021; Gugushvili et al., 2017; Narayan et al., 2018; Song et al., 2020). Early-life and attitudes, and socio-economic and political determinants of population health and wellbeing.

Alexi Gugushvili was supported by a grant (UMO-2018/31/D/HS6/01877) from the National Science Center of Poland under the SONATA 14 program. 
experiences are associated with later-life health, even when comparing individuals with similar living conditions later in life (Hughes et al., 2017; Snyder-Mackler et al., 2020).A well-known accumulation model sees individual health at any one time as the consequence of cumulative exposures to biological, psychosocial, and material circumstances up to that time (Bartley and Plewis, 2007).

Yet, recently researchers have paid closer attention to the effect of the experience of intergenerational mobility on health once the effects of social origin and destination are accounted for (Präg and Gugushvili, 2020). Social mobility has long been thought to affect health in different ways. Most prominently, Sorokin (1927) had suggested that social mobility-irrespective of the direction - is bad for health, while more recently Newman (1999) had theorized that only downward mobility - 'falling from grace'-is a stressful experience. Most research on intergenerational mobility effects on health and wellbeing however suggest that effects are if at all small and sometimes not in the expected direction. Better understanding the mechanisms which link early-life conditions and intergenerational social mobility to later-life health is crucial for creating a level playing field in terms of social justice and for improving population health for all (Venkataramani et al., 2020).

A possible explanation for the apparent lack of strong mobility effects is that the individual perceptions of having been socially mobile might be differing from the objective trajectory between parental and children's occupations. This novel approach is particularly important because the theorized pathways between social mobility and health outcomes primarily refer to various psycho-social mechanisms rather than objective material conditions (Gugushvili et al., 2019). It is known that for current socioeconomic position, subjective appraisals have an effect on health above and beyond objective measures of current socioeconomic position (Hoebel and Lampert, 2020; Präg et al., 2016; Präg, 2020; Tan et al., 2020), suggesting that there is a distinct pathway such as relative deprivation linking subjective appraisals to health (Gugushvili, 2021a; Lahusen and Kiess, 2019; Präg et al., 2014; Wilkinson and Pickett, 2018). But is this also true for subjective perceptions of social mobility?

The psychological effects of social mobility might be relevant only if in- 
dividuals are aware of experiencing upward or downward intergenerational mobility, as it has been argued in research on the behavioral and attitudinal implications of intergenerational social mobility (Schmidt-Catran, 2011). Seymour Martin Lipset (1992), one of the leading political sociologists of the 20th century, asserted that subjective feelings about mobility are more important for political and economic attitudes than objective intergenerational upgrade of educational and occupational status.

Although there is a lack of studies investigating the prevalence and determinants of mismatch between objective and subjective perceptions of social mobility, recent studies suggest that individuals struggle to adequately gauge social mobility in a society as a whole (Alesina et al., 2018; Chambers et al., 2015; Cheng and Wen, 2019; Kraus and Tan, 2015), raising the question whether individuals are able to accurately assess this for themselves. Apart from one recent study (Gugushvili and Präg, 2021), we are also not aware of any research which examines whether or not mismatch between objective and subjective social mobility has any implications for individual health and wellbeing.

In this study, we examine the relationship between objective and subjective mobility in occupational status and health and wellbeing outcomes in representative German survey data. We first theorize why there might be effects of social mobility on health and wellbeing outcomes and how objective and subjective intergenerational mobility might differ from each other in terms of their associations with health. We then describe data, variables, and our analytical strategy. The results show that subjective social mobility is only weakly related to health outcomes, and when comparing individuals with the same objective status background and mobility, it is only life satisfaction that is related to subjective status mobility. 


\section{Theoretical background}

\section{Why social mobility should be associated with health and wellbeing}

Three major hypotheses have linked social mobility to health and wellbeing outcomes. The general idea of social mobility effects is that they are a consequence of the mobility process that is distinct from the results of living conditions in the origin position as well as the improved or worsened living conditions of the destination position. The dissociative hypothesis is the most prominent hypothesis of social mobility effects, going back to Durkheim (1951), who had already suggested that both the upwardly and the downwardly mobile face situations their moral education did not prepare them for, which can lead to psychological distress and anomic suicide. Sorokin (1927) developed this idea further, suggesting that both upwards and downwards mobility lead to dissociation, psychologically distress and mental health problems.

A second hypothesis is the 'falling from grace' hypothesis (Newman, 1999), which posits that it is only downward mobility which is detrimental. Downward mobility goes along with loss and is usually an uncontrollable life event (for instance unemployment or divorce), lowered status, less authority or rewards, and individuals find it often difficult to adapt to a worsened living situation (Gugushvili et al., 2019; Houle and Martin, 2011). Downward mobility goes along with loss of access to social networks such as colleagues, neighbors, a spouse and one's in-laws, problems establishing new social ties in the destination class, and feelings of anger, sadness, and pessimism. Further, the falling from grace hypothesis does not make any predictions about the consequences about upward mobility.

A third hypothesis is the acculturation hypothesis (Blau, 1956), which claims that there are no consequences of social mobility on health and wellbeing. The acculturation hypothesis posits that the mobility experience does not play an important role, instead it is experiences made at origin and destination which shape individual outcomes. Individuals easily adapt to the demands of their new class position, and the current class position rather 
than the origin class position is the main driver of health and wellbeing.

The possible mechanisms linking the social mobility experience to health and wellbeing are access to networks (Berkman et al., 2000), stress (McEwen and Stellar, 1993), and emotions (Fiske, 2011). While the 'falling from grace' hypothesis emphasizes the negative consequences of downward mobility - loss of access to high-status networks, loss of control over one's fate, and feelings of anger and injustice, the dissociative hypothesis also stresses negative consequences of upward mobility - uprooting from old networks such as childhood friends, feeling alienated in one's new high-status environment, and stress from adapting to changed living conditions. The acculturation hypothesis suggests that mobile individuals blend in at their class of destination, based on the same mechanisms that operate at the class of origin.

The acculturation hypothesis finds the strongest support in recent quantitative studies on occupational mobility. Drawing on a number of different methods, data from different countries, a range of different outcome variables, the vast majority of studies do not find strong mobility effects (Chan, 2018; Dhoore et al., 2019; Marshall and Firth, 1999; Präg and Richards, 2019; Zang and de Graaf, 2016; Zhao and Li, 2019; Zhao et al., 2017). In an adjacent research area, Stawarz and Müller (2020) and Paskov et al. (2021) did not find an association between social mobility and concern about immigration. Conversely, there is little support for the dissociation thesis. Becker and Birkelbach (2018) find that upward mobility is detrimental to wellbeing, but only for their subsample of respondents who report not feeling in control of their lives. They do not find a detrimental effect of downward mobility. Similarly, Hadjar and Samuel (2015) also find that upward mobility decreases life satisfaction, but only in the United Kingdom, not in Switzerland, and in neither country they find that downward mobility reduces life satisfaction. For the 'falling from grace' hypothesis, there is some evidence that downward mobility reduces wellbeing, including from different data sources from various countries (Kaiser and Trinh, 2021; Knöchelmann et al., 2020; Nikolaev and Burns, 2014; Tiffin et al., 2005). Most of these studies also find that upward mobility has salubrious effects on wellbeing. 


\section{Objective vs. subjective social mobility}

A possible reason why previous research did not find consistent and systematic associations between social mobility and various health and wellbeing outcomes is that studies disregard individuals' subjective perception of upgrade or downgrade in socio-economic status in comparison to their parents and instead only focus on individuals' objective social mobility experiences, as defined and estimated by social scientists. This can be a crucial distinction as most theoretical channels described above linking mobility experience to health and wellbeing outcomes are based on an implicit assumption that individuals are aware of having experienced upward or downward mobility. For instance, for downward mobility feelings of loss of control, of injustice, anger or alienation require an individual awareness of the mobility process taking place.

What if the assumption that individuals are accurately perceiving the mobility process does not hold? There could be a mismatch between objective indicators and subjective perceptions of mobility (Gugushvili, 2021b). An individual attaining a job which has a lower status than her father's job might not perceive being downwardly mobile, for instance because of a strong preference for taking up a relatively low-status 'helping' occupation. Thus, she might not experience the negative consequences predicted by the dissociative and 'falling from grace' hypotheses, or less negative consequences than her downwardly mobile counterparts who accurately see that they are on a downward slope. Conversely, it is known that, for instance, some immigrants define their mobility experience as upward when it would qualify as downward according to objective definitions of social mobility in terms of occupational class (Segura, 1989). Further, one of the few studies which inquiries into the difference between objective and subjective manifestation of social mobility reveals that there is indeed a non-trivial difference between these two and the size of the gap also depends on the societal context where individuals live (Meraviglia, 2017). Notably, respondents in Northern European countries such as Finland, Denmark, and Sweden, generally report a strong association between the perceived and the actual dimension

of intergenerational mobility, while the weakest associations found in Latin 
American and Asian countries such as Venezuela, the Philippines, and China.

Assuming that there are significant differences between objective and subjective social mobility, first we need to investigate how these two dimensions of social mobility are associated with health and wellbeing. Second, we have to inquire what happens to health and wellbeing when there is a large mismatch between individuals' objective mobility trajectory and subjective perceptions of mobility. In other words, social mobility consequences might be different for individuals who are objectively upwardly mobile but report being downwardly mobile or vice versa. Mechanisms relevant for the dissociative hypothesis, namely facing a novel situation unprepared, might be activated in such a situation.

\section{Data and method}

In this study, we analyze one of the few data-sets that includes information on both individuals' objective and subjective social mobility as well as on their various health outcomes. The German General Social Survey ('Allbus,' Gesis, 2013) in 2010 is a representative cross-sectional survey of the adult resident population in Germany. The full sample is 2,827 respondents, but only a random half of respondents received an additional questionnaire containing our key predictor question about perceived social mobility, which is why we focus on this group in our analysis. After listwise deletion, we end up with 1,012 cases in our analytical sample.

\section{Outcome variables: Health and wellbeing}

In line with the World Health Organization's (WHO) definition of health, we draw on five self-reported outcome variables that gauge not just the physical condition but also the mental wellbeing of individuals, acknowledging health as a multifaceted construct. We follow Hoebel et al. (2013) in the selection of variables: Self-reported health, life satisfaction, and three items recording whether respondents felt depressed, lonely, or felt physical pain in the last four weeks. Histograms are shown in Panel A of Figure 1, also reporting the response options for the five questions. More than half of individuals in our 
A
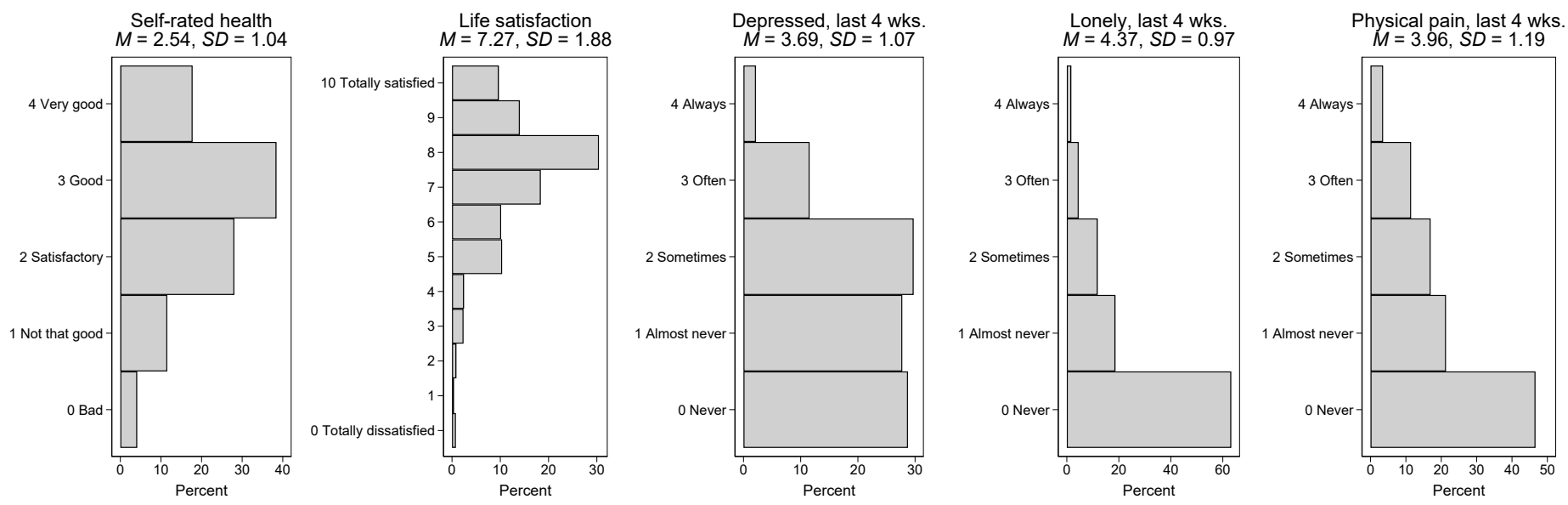

B

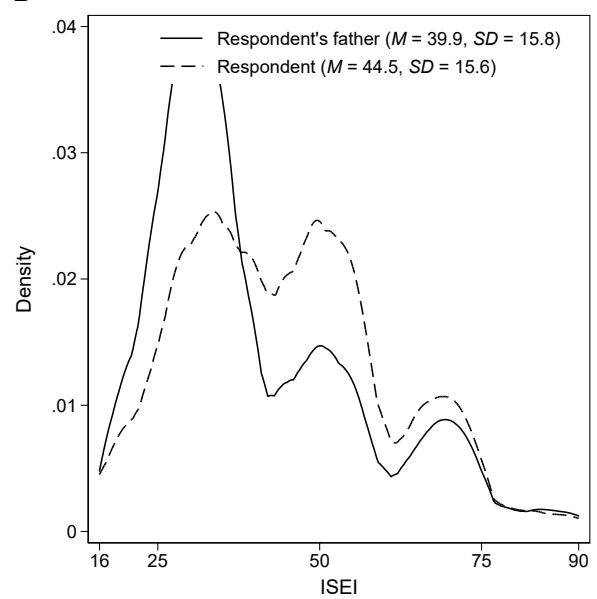

C

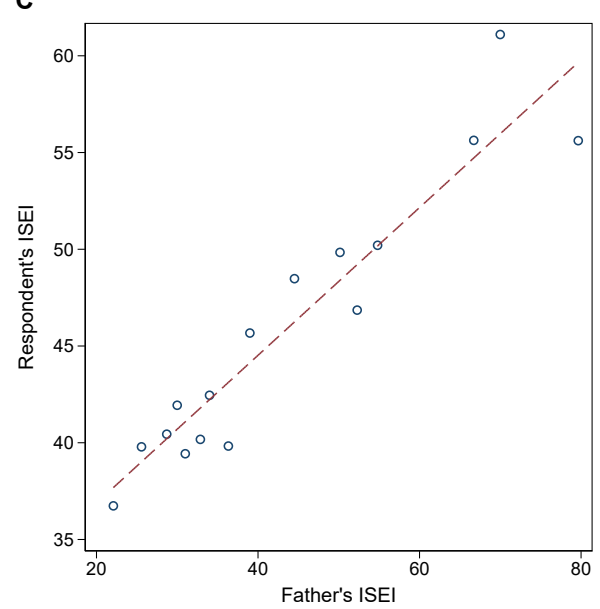

D

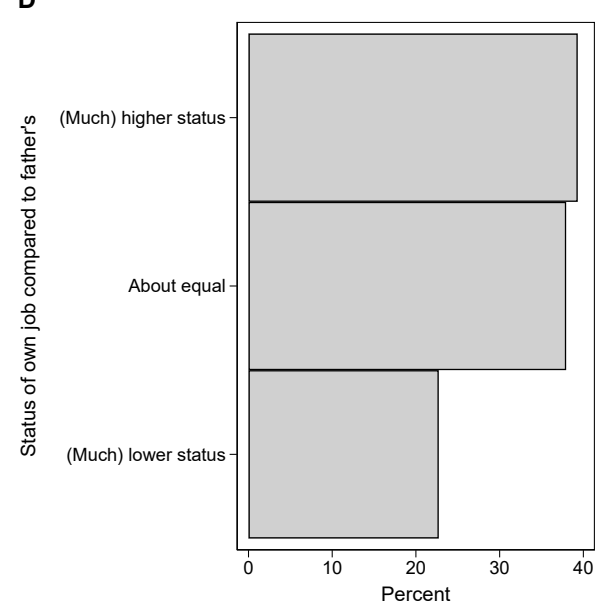

Figure 1: Properties of key variables, $N=1,012$. Panel A: Histograms of outcome variables, Panel B: Density plot of ISEI of respondents and their fathers, Panel C: binned scatterplot of the ISEI of respondents and their fathers, Panel D: histogram of subjective social mobility. 
sample report having either good or very good health. The average value of life satisfaction is $7.3(S D=1.9)$. Feeling depressed sometimes, often, or always was relatively prevalent with 43 per cent of respondents having felt like this in the last four weeks. For the remaining outcome variables almost 65 per cent of respondents report never having felt lonely, while the share of those who never felt pain is much lower at 45 per cent.

\section{Parental and respondents' occupational status}

All respondents of the survey are asked about their father's and mother's occupations when they were 15 , as well as their own occupations at the moment, and if not active on the labor market anymore, their last occupation before leaving the labor market. Collection of this occupational data is conducted with great care, respondents are presented with a show card and two open ended questions to elicit precise descriptions of all occupations of interest and to assign correct occupational codes.

In the following, we focus on paternal social position. The survey question for subjective social mobility explicitly asks about the respondent's father's job status. A corresponding question about mothers was not included in the questionnaire. While the focus on father's occupation and the neglect of mother's occupation seems limiting in contemporary sociological research (Beham et al., 2019), it has to be acknowledged that almost half of all respondents report that their mothers did not work or were helping family members when respondents were 15 years old.

To assess occupational status, we generate International Socio-Economic Index (ISEI, Ganzeboom et al., 1992) scores for parental and respondents' occupation. The index scores occupations based on their average profiles in terms of the income and educational qualifications held by their incumbents, adjusting for age. The ISEI ranges from 16 to 90, with occupational groups like 'domestic helpers and cleaners' having an ISEI of 16, shop salespersons the median ISEI of 43, and judges the highest possible ISEI of 90. The measure is generally considered to be valid and is frequently used in research on social stratification (Connelly et al., 2016). The distribution of respondent's and father's ISEI scores can be seen in Panel B of Figure 1. The Panel reveals 
the well-known pattern of economic development and occupational upgrading in the twentieth century: In the respondents' generation higher status jobs, particularly in the middle of the distribution up to the ISEI score of 65 , are more common than in the generation of their fathers. Panel $\mathrm{C}$ shows a binned scatterplot of father's and son's ISEI, illustrating the intergenerational persistence of occupational status: The higher one's father's ISEI, the higher one's own ISEI, yet this Figure also suggests that some individuals experience downward mobility, while others experience upward mobility.

\section{Social mobility: objective and subjective}

To assess objective social mobility, we convert the ISEI scores of respondents and their fathers into tertiles. By doing so, we can account for any health and wellbeing effects stemming from the changes in the occupational structure in Germany shown in Panel B of Figure 1. Then we classify respondents as upwardly and downwardly mobile if they are, respectively, in a higher and lower ISEI tertile than their fathers. The remaining respondents are considered to be non-mobile. We cannot simultaneously control for respondents and father's ISEI tertiles when modeling the effect of the difference between father's and respondent's ISEI tertiles, as the three are linearly dependent (Van der Waal et al., 2017). Instead, we analyze how specific social mobility trajectories are associated with health and wellbeing outcomes. For this purpose, we construct a social mobility variable by cross-tabulating the respondents' and their fathers' ISEI tertiles in nine trajectories: (1) the stably low, (2) low to medium; (3) low to high; (4) medium to low; (5) stably medium; (6) medium to high; (7) high to low; (8) high to medium; and (9) stably high.

To gauge subjective social mobility, we draw on a survey question prompting respondents to compare their job to their father's job when they were 15 years old. Answers were recorded in five response categories, ranging from 'much lower' to 'much higher.' This question has been used and validated previously (Kelley and Kelley, 2009; Meraviglia, 2017). A histogram is shown in Panel D of Figure 1. The largest category of respondents reports no social mobility, but more respondents report upward mobility than downward 
mobility, which is in line with the findings from objective social status in Panel B of Figure 1. For reasons of statistical power and comparability with objective mobility, we collapsed the 'much higher' and 'higher' categories as well as the 'much lower' and 'lower' categories into two pooled categories: '(much) higher' and '(much) lower.'

\section{Control variables}

To obtain robust estimates for our measures of intergenerational social mobility, we control for a limited number of variables in our analyses: $\operatorname{sex}(1=\mathrm{fe}-$ male, $0=$ male), age, German region $(1=$ Eastern, $0=$ Western $)$, and marital status $(1=$ divorced/widowed, $2=$ never married, $0=$ married $)$. Further, we control for respondent's education ( $0=$ up to lower secondary, 1 = upper secondary and post-secondary, $2=$ tertiary) and labor market status ( 0 = working, $1=$ retired, 2 = unemployed, $3=$ other) in a set of robustness analyses. Descriptive statistics for all variables can be found in Table A1 in the supplementary materials.

\section{Analytical strategy}

We make use of ordinary least squares (OLS) regression to model our outcome variables in the main text. As robustness checks, we draw on alternative approaches reported at the end of the results section. For replicating all analyses, we provide a Stata 15 do-file on-line (Präg and Gugushvili, 2021).

\section{Ethics approval}

Given that this is a secondary analysis using data publicly available on-line, approval by an ethics review board was not required. 


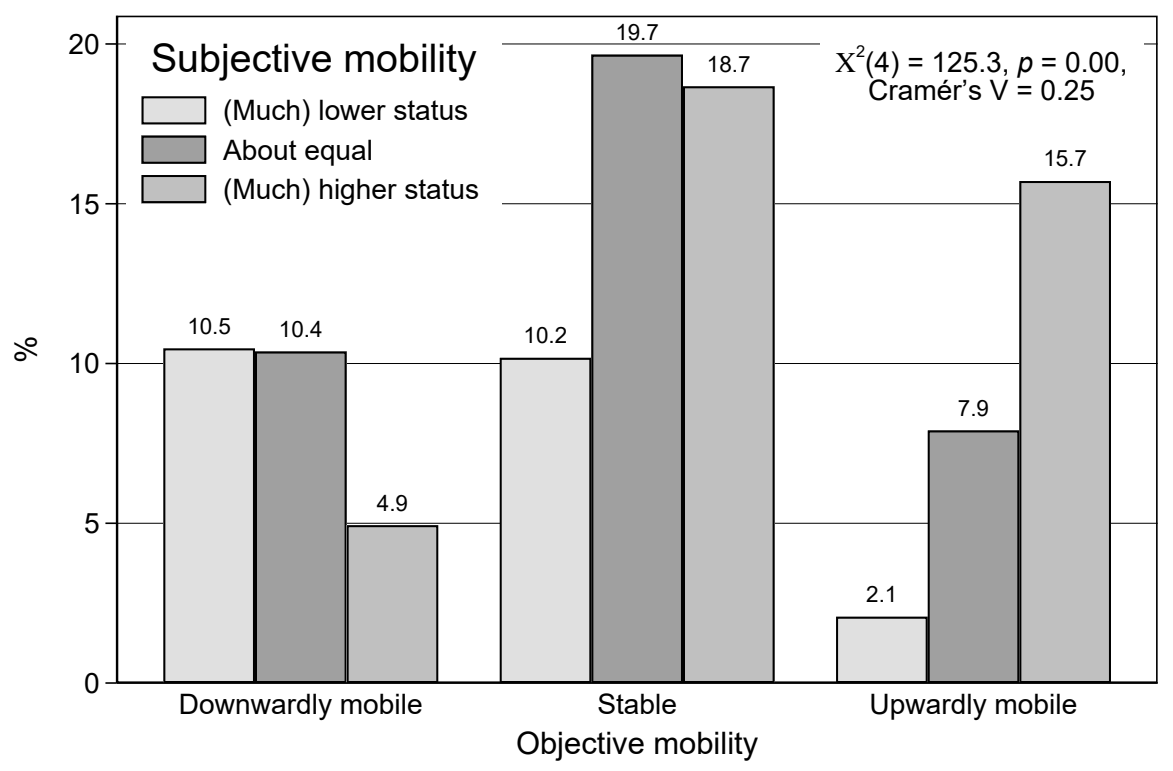

Figure 2: Subjective and objective status mobility are correlated. Bar chart cross-classifying objective by subjective social mobility, $N=1,012$.

\section{Results}

\section{Do individuals perceive their social mobility accurately?}

To better understand the role of social mobility for health, we assess in how far respondents are able to accurately gauge their social mobility. For this, we compare the subjective appraisal of social mobility to the objective measure of mobility. Figure 2 shows that respondents' reports of social mobility are associated with their objective social mobility. Within each objective mobility category, the highest share of respondents holds the corresponding subjective appraisal, e.g. 19.7 per cent of respondents have not been socially mobile and do not consider themselves to have been socially mobile. While statistically significant $\left(\chi^{2}(4)=125.3, p=.00\right)$, this association is far from perfect, with a Cramér's $V=.25$. For instance, almost as many respondents who have been socially downward mobile consider themselves stable as those who consider themselves downwardly mobile, while further 4.9 per cent of the downwardly mobile consider themselves being upwardly mobile. Part of this is due to the occupational upgrading - respondents might have similar 
or slightly better jobs as their fathers and thus consider themselves immobile or even upwardly mobile, but the upwards shift in occupations makes them downwardly mobile when intergenerational mobility is measured in relative terms.

\section{How is social mobility associated with health and well- being outcomes?}

The top panel A of Figure 3 shows that there are no consistent and systematic links between objective social mobility trajectories and health and wellbeing outcomes. Nonetheless, some interesting associations can be detected in the depicted results. When compared with individuals in the stably medium category, those who are in stable high group are significantly more likely to report better overall health, higher life satisfaction and lower prevalence of pain, depression, and loneliness, while downwardly mobile individuals from the top tertile to lower tertiles are virtually indistinguishable from individuals in the stable medium category. Furthermore, those who experience downward mobility from the medium to the low tertile are more likely to report worse overall health and physical pain. In turn, those in the stable low category report worse health and wellbeing outcomes, but only for reporting pain in last four weeks prior to the interview 95 per cent confidence intervals of our estimates do not overlap with the zero-reference line.

Panel B of Figure 3 (hollow dots) focuses on the health implications of subjective mobility to address the question whether individuals who perceive having been upwardly or downwardly mobile report also different health and wellbeing outcomes compared to those who perceive themselves as socially immobile. As was the case for objective social mobility estimates, we do not find that subjective perception of intergenerational mobility is consistently and systematically related to health and wellbeing outcomes. For self-reported health as well as for pain and depression, we do not find any significant associations. For life satisfaction, those in the higher status group report higher life satisfaction at conventional levels of statistical significance. Those who perceive themselves as downwardly mobile are also more lonely. Once we account for objective mobility trajectories (black dots in Panel B 
A

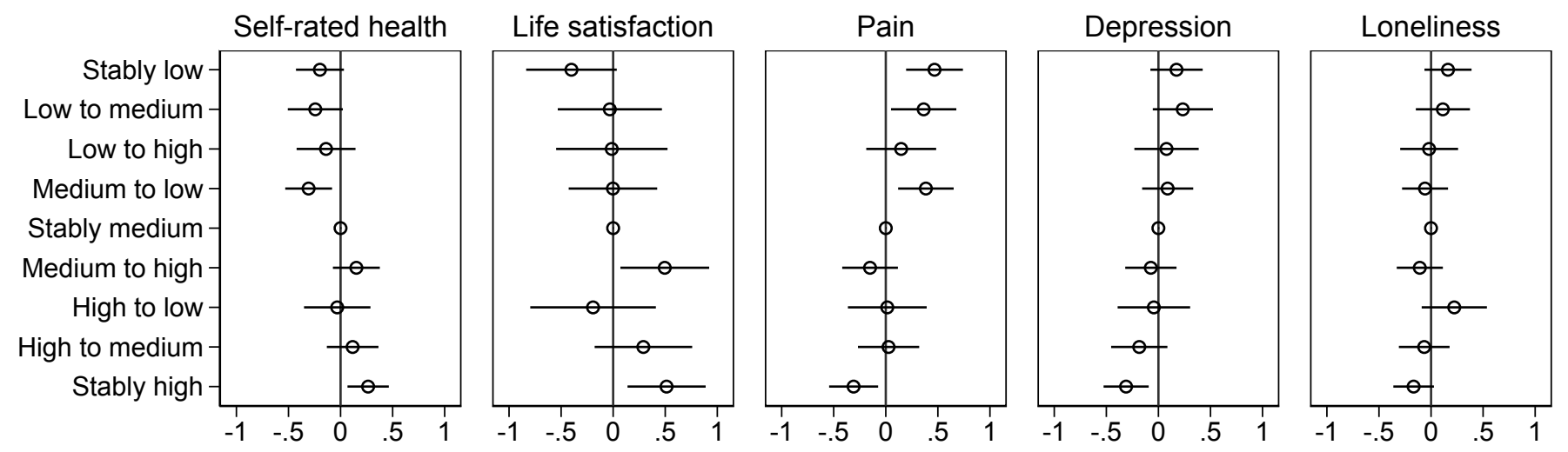

B
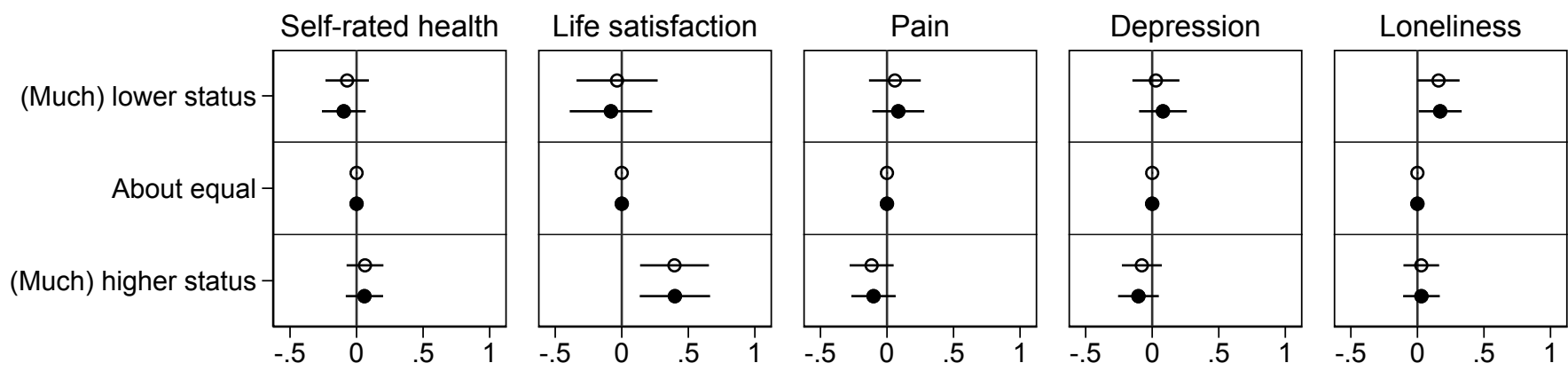

- Not controlling for objective mobility trajectories

- Controlling for objective mobility trajectories

Figure 3: Panel A: Health outcomes regressed on objective social mobility in OLS regression models, controlling for age, sex, marital status, and region, $N=1,012$. Full results reported in Table A2. Panel B: Health outcomes regressed on subjective social mobility in OLS regression models, controlling for age, sex, marital status, and region (and objective mobility trajectories), $N=1,012$. Full results reported in Table A3. 
of Figure 3), we can see that this pattern holds: Feeling upwardly mobile is beneficial for life satisfaction and feeling downwardly mobile goes along with more frequent feelings of loneliness, irrespective of the objective mobility trajectory.

\section{What if objective social mobility and subjective percep- tion diverge?}

A

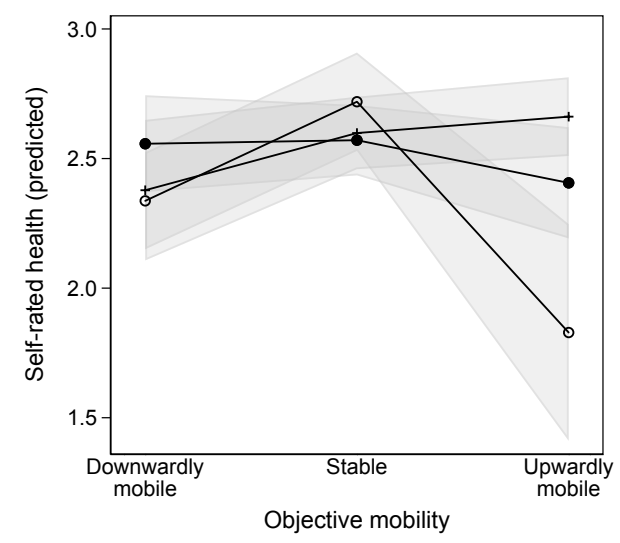

D

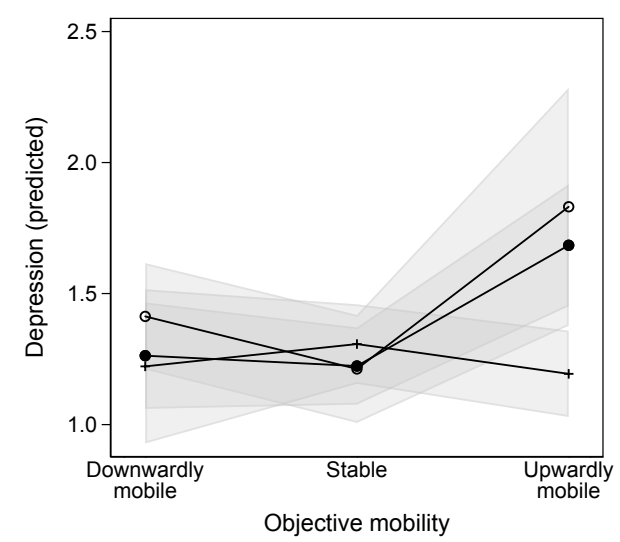

B

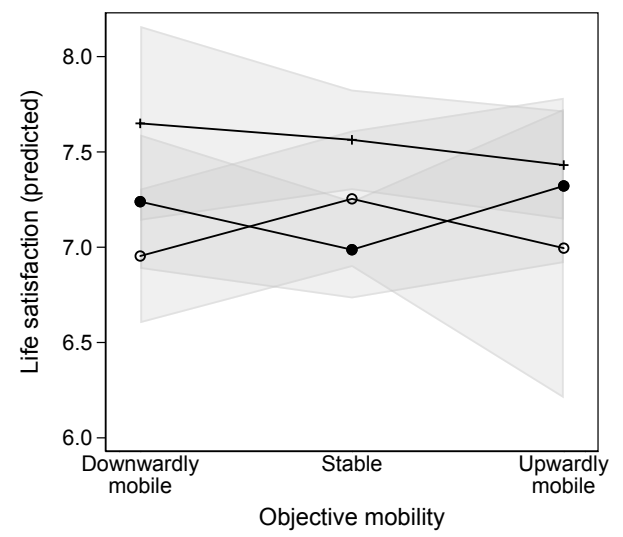

E

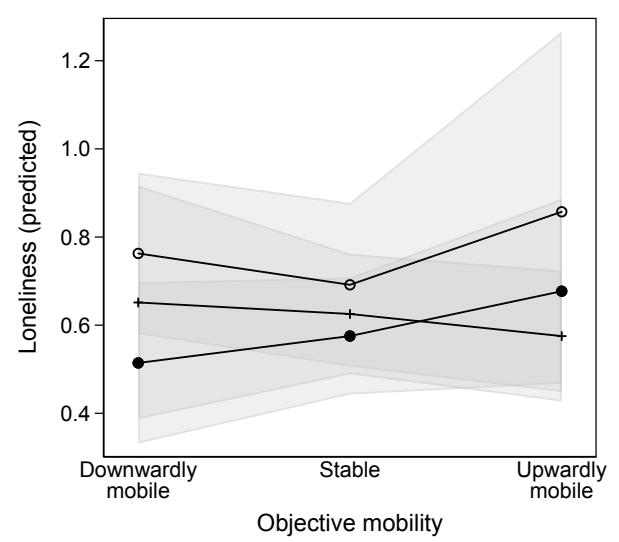

C

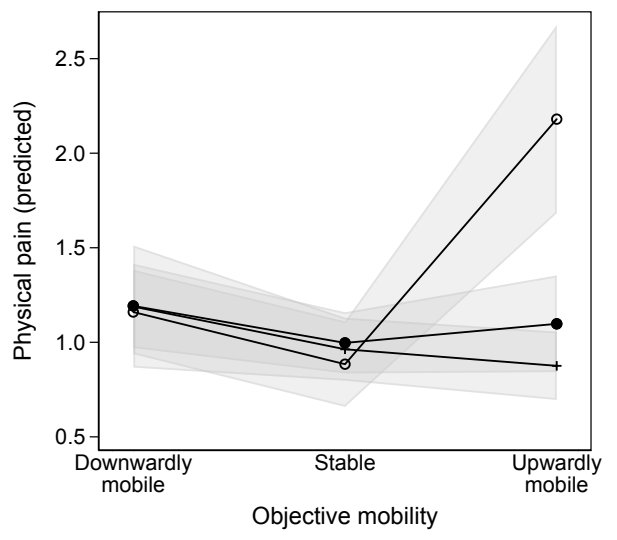

Subjective mobility

- - (Much) lower status

$\longrightarrow$ About equal

(Much) higher status

Figure 4: Interactions between subjective and objective social mobility, results from OLS regression models controlling for age, sex, marital status, and German region, $N=1,012$. Full models shown in Table A4. 
In order to test if mismatch between objective and subjective mobility has implications for health and wellbeing outcomes, we estimated regressions with interactions between both types of mobility. The results are shown in Figure 4. We have to be cautious with the interpretations of these results on the margins as only a small share of individuals report a long-distance mismatch - subjectively/objectively lower vs. objectively/subjectively higher. Although most interactions are not statistically significant, a few interesting associations are observed for those who are objectively mobile but have varying subjective perceptions of social mobility. Those who experienced objective upward mobility but declare they have lower status than their fathers, pessimists so to say, are much more likely to experience physical pain, depression, and report lower self-rated health than those who declare they have higher status than their fathers. Conversely, respondents who accurately assess their mobility or who overestimate their mobility success, optimists so to say, do not experience health advantages.

\section{Robustness checks}

We conduct a number of checks to assess the robustness of our results, which we present in detail in the on-line appendix. We have submitted this document to the journal and also make it available here. Firstly, we compared

our analytical sample - the random half of the sample which had received the questionnaire with the subjective social mobility question - to the rest of the sample which did not have to answer the question. For this, we look at the five outcome variables as well as respondent's and father's ISEI scores. Figure A1 shows that there is no substantial difference and that the randomization of questionnaires was successful. Secondly, we added an age-squared term to our equations to take into account any curvilinear associations between age and outcome variables (Tables A5 to A7). The age-squared term hardly ever reaches conventional levels of statistical significance and including it does not alter our substantive findings. Thirdly, we controlled for education in our models (Tables A8 to A10). Expectedly, education is associated with better health outcomes and life satisfaction, except when the outcome variable is feeling lonely. Accounting for education removes some of the effects ob- 
served for objective social mobility trajectories, but the results are virtually unaffected for subjective perception of social mobility - those who declare experiencing upward mobility report higher life satisfaction. Fourthly, we account for labor market status in our models (Tables A11 to A13). Results stay substantively the same. Fifthly, we reran analyses using the weights provided by the data providers (Tables A14 to A16), yielding substantively similar results. Finally, we ran analyses as ordered logit models (Tables A17 to A19), which leads to the same substantive conclusions.

\section{Discussion}

Using a representative sample of the German population, we have explored the link of subjective and objective social mobility to health and wellbeing. In line with previous studies, we only find a weak and inconsistent association between objective social mobility trajectories and health and wellbeing outcomes. Further, we show that individuals are generally able to gauge their occupational mobility relatively accurately, but that relationship is far from perfect. Many are prone to see their mobility trajectory in a more positive light than the objective indicators suggest and vice versa. This perceived social mobility is associated with some health outcomes. For life satisfaction, perceived upward mobility has salubrious effects, but not for any of the other four outcomes. In turn, perceived downward mobility goes along with greater loneliness, but no other health outcome does so. Notably, these associations hold even when individuals with the same objective mobility trajectories are being compared. Further, when subjective perceptions of mobility diverge from the objective mobility trajectory, this sometimes has consequences: Perceiving downward mobility when having been upwardly mobile is associated with higher prevalence of physical pain (a health outcome of growing importance, Case et al., 2020; Zajacova et al., 2021) and worse self-rated health.

A key finding of our study is that perceived social mobility has associations with health outcomes irrespective of objective social mobility. This is however only true for life satisfaction and loneliness. Establishing such a link is an important first step, raising the question what is underlying this 
association. Is this the result of a distinct psycho-social pathway linking perceptions of social standing to health, a reflection of imperfect measurement of social mobility, or due to an endogenous link between subjective mobility and life evaluation? A broader measure of family background, both of the socioeconomic position of respondents as well as of their parents, would be useful for testing whether this is due to measurement problems of social mobility. Similarly, having different measures of cognitive life evaluation on the one hand and emotional and affective wellbeing on the other (Diener et al., 2010; Kahneman and Deaton, 2010) would allow to explore whether the link between subjective appraisals of mobility and life satisfaction is due to cognitive appraisals of one's life in general or due to actual positive emotions. Establishing that the association between perceptions and health is genuine would be a major step forward for understanding how social inequality gets under the skin and how psycho-social mechanisms are driving population health.

Another intriguing finding is that we reveal the largest effects for life satisfaction rather than for a more traditional health outcome. Arguably some theoretical explanations of social mobility are more closely associated with measures of life satisfaction and self-reported health rather than tangible physical health indicators. Based on previous research, it is unlikely that mobility effects will be manifested in 'wear and tear' of the body (Präg and Richards, 2019) and consequently in physical pain caused by mobility experience per se. It seems more likely that social mobility has an effect on those aspects of health which are more closely related to psychological health and wellbeing, such as suffering from loneliness after moving up in social hierarchy - e.g. being isolated and not having strong social network in the destination social class. Also, for downward social mobility subjective perception presumably relates more closely to psychological aspects of health and wellbeing than does objective intergenerational mobility. For instance, according to relative risk aversion theory (Breen et al., 2014), one's main objective is to avoid downward mobility, as downward mobility leads to dissatisfaction with life. Those individuals who were not able to keep up with family aspirations are expected to report lower levels of satisfaction with life but to what extend this frustration translates into physical health outcomes 
is not clear.

Specific features of the German case raise questions whether our findings can be generalized to other countries. Germany is historically a country with relatively low social mobility (Breen and Müller, 2020; Bukodi et al., 2020; Erikson and Goldthorpe, 1992), which on the one hand might affect perceptions of mobility as being more exceptional and on the other hand less variation might make it more difficult to detect associations. Nonetheless, research has suggested that the links between objective and subjective social mobility in Germany are stronger than in other countries (Meraviglia, 2017), thus the role of subjective social mobility might play a bigger role in countries where the link is less straightforward (e.g. the US, Berger and Engzell, 2020). Another limitation of our study is that we can only look at self-reported health outcomes - using biomarkers such as done by Präg and Richards (2019) would hopefully provide more conclusive evidence. Further, our study relies on cross-sectional data. Having multiple observations of participants' occupational status attainment over the life course, their subjective perception of that, and health outcomes would allow us to rule out possible confounders such as personality and other participant traits. We are not aware of the existence of such a data set, yet believe that future research should take this avenue to further assess the robustness of the findings reported here.

Further, our study has focused on individual past mobility experiences rather than expectations about perceived mobility opportunities now and in the future (as suggested by the 'prospect of upward mobility' hypothesis, Benabou and Ok, 2001), or rather than beliefs about the extent of social mobility in a society (e.g. Cheng and Wen, 2019). How would other types of mobility experiences affect health and wellbeing? Perceived opportunities in the present or the future might buffer against negative experiences or have positive effects on wellbeing, yet disappointments in the face of high expectations might lead to lower wellbeing (Day and Fiske, 2019; Phillips et al., 2020). Aggregate social mobility in a society or area can be seen as a proxy of mobility opportunities for individuals. (Präg and Gugushvili, 2020) analyze the association between average social mobility levels in a society and self-rated health, and find no association, neither for the difficult-to- 
perceive relative social mobility (i.e. net of the sizes of social classes) nor for the easier-to-perceive absolute social mobility (e.g. the share of people who end up in a better position than their parents), though other ecological studies find an association between relative social mobility and mortality in the United States and Europe (Gugushvili and Kaiser, 2020; Venkataramani et al., 2015). Beliefs about the general social mobility of a society are associated with attitudes, for instance economic fairness (Heiserman et al., 2020), yet according to the review by Day and Fiske (2019) there is no evidence for an association between beliefs about mobility in a society and wellbeing.

Using additional wellbeing outcome variables (e.g. Diener et al., 2010) would allow us to obtain further insights into the consequences of objective and perceived social mobility. Marshall and Firth (1999) revealed that there is no association between objective social mobility and satisfaction with different life domains, yet Day and Fiske (2019) highlight that mobility beliefs may affect several aspects of wellbeing, such as positive affect, emotional episodes, or distress, rather than mere satisfaction measures.

Overall, it has to be stated that the effects of both subjective and objective social mobility on health are not large. The subjective mobility effects for life satisfaction and loneliness range between a sixth and a fifth of a standard deviation (Figure 3, Panel B). This is considerably smaller than the differences between the objectively stable individuals (Figure 3, Panel A). Hopes that the oft-hypothesized yet empirically elusive social mobility effects would exist in the minds of respondents (rather than only in the minds of sociologists) appear to remain unfulfilled in this study. In conclusion, our novel test of subjective and objective social mobility effects on health lends further support to the old acculturation hypothesis (Blau, 1956) which suggest that social mobility experience, and in our case perceptions of social mobility, is not the major factor affecting individuals' health.

\section{References}

Agresti, Allan, 2010. Analysis of Ordinal Categorical Data. Hoboken, NJ:

Wiley, 2nd edition. doi: 10.1002/9780470594001. 
Alesina, Alberto, Stefanie Stantcheva, and Edoardo Teso, 2018. 'Intergenerational Mobility and Preferences for Redistribution.' American Economic Review 108(2): 521-54. doi: 10.1257/aer.20162015.

Angrist, Joshua David and Jörn-Steffen Pischke, 2009. Mostly Harmless Econometrics. An Empiricist's Companion. Princeton, NJ: Princeton University Press.

Bartley, Mel and Ian Plewis, 2007. 'Increasing Social Mobility. An Effective Policy to Reduce Health Inequalities.' Journal of the Royal Statistical Society A 170(2): 469-481. doi: 10.1111/j.1467-985X.2006.00464.x.

Becker, Dominik and Klaus Birkelbach, 2018. 'Social Mobility and Subjective Wellbeing Revisited. The Importance of Individual Locus of Control.' Research in Social Stratification and Mobility 54: 1-20. doi: 10.1016/j.rssm.2018.01.001.

Beham, Barbara, Sonja Drobnič, Patrick Präg, Andreas Baierl, and Janin Eckner, 2019. 'Part-Time Work and Gender Inequality in Europe. A Comparative Analysis of Satisfaction with Work-Life Balance.' European Societies 21(3): 378-402. doi: 10.1080/14616696.2018.1473627.

Benabou, Roland and Efe A. Ok, 2001. 'Social Mobility and the Demand for Redistribution. The POUM Hypothesis.' Quarterly Journal of Economics 116(2): 447-487. doi: 10.1162/00335530151144078.

Berger, Thor and Per Engzell, 2020. 'Trends and Disparities in Subjective Upward Mobility since 1940.' Socius 6: 1-11. doi: $10.1177 / 2378023120951139$.

Berkman, Lisa F., Thomas Glass, Ian Brissette, and Teresa E. Seeman, 2000. 'From Social Integration to Health. Durkheim in the New Millennium.' Social Science and Medicine 51(6): 843-857. doi: 10.1016/S02779536(00)00065-4.

Blau, Peter M., 1956. 'Social Mobility and Interpersonal Relations.' American Sociological Review 21(3): 290-295. doi: 10.2307/2089282. 
Breen, Richard and Walter Müller, 2020. Education and Intergenerational Social Mobility in Europe and the United States. Studies in social inequality. Stanford, CA: Stanford University Press. doi: 10.11126/stanford/9781503610163.001.0001.

Breen, Richard, Herman G. van de Werfhorst, and Mads Meier Jæger, 2014. 'Deciding under Doubt. A Theory of Risk Aversion, Time Discounting Preferences, and Educational Decision-Making.' European Sociological Review 30(2): 258-270. doi: 10.1093/esr/jcu039.

Bukodi, Erzsébet and Marii Paskov, 2020. 'Intergenerational Class Mobility among Men and Women in Europe. Gender Differences or Gender Similarities?' European Sociological Review 36(4): 495-512. doi: 10.1093/esr/jcaa001.

Bukodi, Erzsébet, Marii Paskov, and Brian Nolan, 2020. 'Intergenerational Class Mobility in Europe. A New Account.' Social Forces 98(3): 941-972. doi: $10.1093 / \mathrm{sf} / \mathrm{soz} 026$.

Case, Anne, Angus Deaton, and Arthur A. Stone, 2020. 'Decoding the Mystery of American Pain Reveals a Warning for the Future.' Proceedings of the National Academy of Sciences 117(40): 24785-24789. doi: 10.1073/pnas.2012350117.

Chambers, John R., Lawton K. Swan, and Martin Heesacker, 2015. 'Perceptions of US Social Mobility Are Divided (and Distorted) Along Ideological Lines.' Psychological Science 26(4): 413-423. doi: $10.1177 / 0956797614566657$.

Chan, Tak Wing, 2018. 'Social Mobility and the Wellbeing of Individuals.' British Journal of Sociology 69(1): 183-206. doi: 10.1111/14684446.12285 .

Cheng, Siwei and Fangqi Wen, 2019. 'Americans Overestimate the Intergenerational Persistence in Income Ranks.' Proceedings of the National Academy of Sciences 116(28): 13909-13914. doi: 10.1073/pnas. 1814688116 . 
Connelly, Roxanne, Vernon Gayle, and Paul S. Lambert, 2016. 'A Review of Occupation-Based Social Classifications for Social Survey Research.' Methodological Innovations 9: 1-14. doi: 10.1177/2059799116638003.

Day, Martin V. and Susan T. Fiske, 2019. 'Understanding the Nature and Consequences of Social Mobility Beliefs.' In Jetten, Jolanda and Kim Peters, eds., The Social Psychology of Inequality, pp. 365-380. doi: 10.1007/978-3-030-28856-3_23.

Deaton, Angus, 2018. The Analysis of Household Surveys. A Microeconometric Approach to Development Policy. Washington DC: World Bank, 2nd edition. doi: 10.1596/978-1-4648-1331-3.

Dhoore, Jasper, Stijn Daenekindt, and Henk Roose, 2019. 'Social Mobility and Life Satisfaction across European Countries. A Compositional Perspective on Dissociative Consequences of Social Mobility.' Social Indicators Research 144(3): 1257-1272. doi: 10.1007/s11205-019-02083-2.

Diener, Ed, Weiting Ng, James Harter, and Raksha Arora, 2010. 'Wealth and Happiness Across the World. Material Prosperity Predicts Life Evaluation, Whereas Psychosocial Prosperity Predicts Positive Feeling.' Journal of Personality and Social Psychology 99(1): 52-61. doi: 10.1037/a0018066.

Durkheim, Emile, 1951. Suicide. New York: Free Press.

Erikson, Robert and John H. Goldthorpe, 1992. The Constant Flux. A Study of Class Mobility in Industrial Societies. Oxford: Clarendon.

Eurofound, 2017. Social Mobility in the EU. Dublin: European Foundation for the Improvement of Living and Working Conditions. doi: $10.2806 / 420671$.

Fiske, Susan T., 2011. Envy Up, Scorn Down. How Status Divides Us. New York: Russell Sage.

Ganzeboom, Harry B. G., Paul M. de Graaf, and Donald J. Treiman, 1992. 'A Standard International Socio-Economic Index of Occupational Status.' Social Science Research 21(1): 1-56. doi: 10.1016/0049-089X(92)90017-B. 
Gelman, Andrew, 2007. 'Struggles with Survey Weighting and Regression Modeling.' Statistical Science 22(2): 153-164. doi: 10.1214/088342306000000691.

Gesis, 2013. German General Social Survey (ALLBUS) 2010. Cologne: GESIS Data Archive, 1.0.1 edition. doi: 10.4232/1.11782.

Grätz, Michael, Kieron J. Barclay, Øyvind Wiborg, Torkild H. Lyngstad, Aleksi Karhula, Jani Erola, Patrick Präg, Thomas Laidley, and Dalton Conley, 2021. 'Sibling Similarity in Education Across and Within Societies.' Demography 58(3): 1011-1037. doi: 10.1215/00703370-916402.

Gugushvili, Alexi, 2021a. 'Which Socio-Economic Comparison Groups Do Individuals Choose and Why?' European Societies 23(4): 437-463. doi: 10.1080/14616696.2020.1793214.

— 2021b. 'Why Do People Perceive Themselves as Being Downwardly or Upwardly Mobile?' Acta Sociologica 64(1): 3-23. doi: 10.1177/0001699320929742.

Gugushvili, Alexi, Erzsébet Bukodi, and John H. Goldthorpe, 2017. 'The Direct Effect of Social Origins on Social Mobility Chances. 'Glass Floors' and 'Glass Ceilings' in Britain.' European Sociological Review 33(2): 305316. doi: 10.1093/esr/jcx043.

Gugushvili, Alexi and Caspar Kaiser, 2020. 'Equality of Opportunity is Linked to Lower Mortality in Europe.' Journal of Epidemiology and Community Health 74(2): 151. doi: 10.1136/jech-2019-212540.

Gugushvili, Alexi and Patrick Präg, 2021. 'Intergenerational Social Mobility and Health in Russia. Mind over Matter?' Advances in Life Course Research 47(100390): 1-13. doi: 10.1016/j.alcr.2020.100390.

Gugushvili, Alexi, Yizhang Zhao, and Erzsébet Bukodi, 2019. "Falling from Grace' and 'Rising from Rags.' Intergenerational Educational Mobility and Depressive Symptoms.' Social Science \& Medicine 222: 294-304. doi: 10.1016/j.socscimed.2018.12.027. 
Hadjar, Andreas and Robin Samuel, 2015. 'Does Upward Social Mobility Increase Life Satisfaction? A Longitudinal Analysis Using British and Swiss Panel Data.' Research in Social Stratification and Mobility 39: 4858. doi: 10.1016/j.rssm.2014.12.002.

Heiserman, Nicholas, Brent Simpson, and Robb Willer, 2020. 'Judgments of Economic Fairness Are Based More on Perceived Economic Mobility Than Perceived Inequality.' Socius 6: 1-12. doi: 10.1177/2378023120959547.

Hoebel, Jens, Benjamin Kuntz, Stephan Müters, and Thomas Lampert, 2013. 'Subjektiver Sozialstatus und gesundheitsbezogene Lebensqualität bei Erwachsenen in Deutschland. Ergebnisse der Allgemeinen Bevölkerungsumfrage der Sozialwissenschaften (Allbus 2010).' Gesundheitswesen 75(10): 643-651. doi: 10.1055/s-0032-1333211.

Hoebel, Jens and Thomas Lampert, 2020. 'Subjective Social Status and Health. Multidisciplinary Explanations and Methodological Challenges.' Journal of Health Psychology 25(2): 173-185. doi: $10.1177 / 1359105318800804$.

Houle, Jason N. and Molly A. Martin, 2011. 'Does Intergenerational Mobility Shape Psychological Distress? Sorokin Revisited.' Research in Social Stratification and Mobility 29(2): 193-203. doi: 10.1016/j.rssm.2010.11.001.

Hughes, Karen, Mark A. Bellis, Katherine A. Hardcastle, Dinesh Sethi, Alexander Butchart, Christopher Mikton, Lisa Jones, and Michael P. Dunne, 2017. 'The Effect of Multiple Adverse Childhood Experiences on Health. A Systematic Review and Meta-Analysis.' The Lancet Public Health 2(8): e356-e366. doi: 10.1016/S2468-2667(17)30118-4.

Kahneman, Daniel and Angus Deaton, 2010. 'High Income Improves Evaluation of Life but not Emotional Wellbeing.' Proceedings of the National Academy of Sciences 107(38): 16489-16493. doi: 10.1073/pnas.1011492107.

Kaiser, Caspar and Nhat An Trinh, 2021. 'Positional, Mobility, and Reference Effects. How Does Social Class Affect Life Satisfaction in Europe?' European Sociological Review 37: 713-730. doi: 10.1093/esr/jcaa067. 
Kelley, Sarah M.C. and Claire G.E. Kelley, 2009. 'Subjective Social Mobility. Data from Thirty Nations.' In Haller, Max, Roger Jowell, and Tom W. Smith, eds., The International Social Survey Programme 19842009. Charting the Globe, pp. 106-124. New York: Routledge. doi: 10.4324/9780203880050-14.

Knöchelmann, Anja, Sebastian Günther, Irene Moor, Nico Seifert, and Matthias Richter, 2020. 'Social Mobility, Accumulation of Disadvantages, and Health. An Analysis with Retrospective Data from the GSOEP (200214).' European Journal of Public Health 30(1): 98-104. doi: 10.1093/eurpub/ckz128.

Kraus, Michael W. and Jacinth J. X. Tan, 2015. 'Americans Overestimate Social Class Mobility.' Journal of Experimental Social Psychology 58: 101111. doi: $10.1016 /$ j.jesp.2015.01.005.

Lahusen, Christian and Johannes Kiess, 2019. 'Subjective Europeanization. Do Inner-European Comparisons Affect Life Satisfaction?' European Societies 21(2): 214-236. doi: 10.1080/14616696.2018.1438638.

Lipset, Seymour Martin, 1992. 'The Political Consequences of Social Mobility.' In Turner, Frederick, ed., Social Mobility and Political Attitudes. Comparative Perspectives, pp. xv-xxiii. Transaction.

Marshall, Gordon and David Firth, 1999. 'Social Mobility and Personal Satisfaction. Evidence from Ten Countries.' British Journal of Sociology 50(1): 28-48. doi: 10.1111/j.1468-4446.1999.00028.x.

McEwen, Bruce S. and Eliot Stellar, 1993. 'Stress and the Individual. Mechanisms Leading to Disease.' Archives of Internal Medicine 153(18): 20932101. doi: 10.1001/archinte.1993.00410180039004.

Meraviglia, Cinzia, 2017. 'The Social Ladder. Status Mobility Across Time and Countries.' In Edlund, Jonas, Insa Bechert, and Markus Quandt, eds., Social Inequality in the Eyes of the Public. A Collection of Analyses Based on ISSP Data 1987-2009, pp. 13-33. Cologne: Gesis. doi: 10.21241/ssoar.57225. 
Mood, Carina, 2010. 'Logistic Regression. Why We Cannot Do What We Think We Can Do, and What We Can Do About It.' European Sociological Review 26(1): 67-82. doi: 10.1093/esr/jcp006.

Narayan, Ambar, Roy van der Weide, Alexandru Cojocaru, Christoph Lakner, Silvia Redaelli, Daniel Gerszon Mahler, Rakesh Gupta N. Ramasubbaiah, and Stefan Thewissen, 2018. Fair Progress? Economic Mobility Across Generations Around the World. Washington, DC: World Bank. doi: 10.1596/978-1-4648-1210-1.

Newman, Katherine S., 1999. Falling from Grace. Downward Mobility in the Age of Affluence. Berkeley, CA: University of California Press, 2nd edition.

Nikolaev, Boris and Ainslee Burns, 2014. 'Intergenerational Mobility and Subjective Wellbeing. Evidence from the General Social Survey.' Journal of Behavioral and Experimental Economics 53: 82-96. doi: 10.1016/j.socec.2014.08.005.

Paskov, Marii, Patrick Präg, and Lindsay Richards, 2021. 'Does Downward Social Mobility Make People More Hostile Towards Immigrants?' Research in Social Stratification and Mobility 72(100543): 1-11. doi: 10.1016/j.rssm.2020.100543.

Phillips, L. Taylor, Sean R. Martin, and Peter Belmi, 2020. 'Social Class Transitions. Three Guiding Questions for Moving the Study of Class to a Dynamic Perspective.' Social and Personality Psychology Compass 14(9): 1-18. doi: 10.1111/spc3.12560.

Präg, Patrick, Melinda Mills, and Rafael Wittek, 2014. 'Income and Income Inequality as Social Determinants of Health. Do Social Comparisons Play a Role?' European Sociological Review 30(2): 218-229. doi: $10.1093 /$ esr $/$ jct035.

Präg, Patrick, 2020. 'Subjective Socio-Economic Status Predicts SelfRated Health Irrespective of Objective Family Socio-Economic Background.' Scandinavian Journal of Public Health 48(7): 707-714. doi: 10.1177/1403494820926053. 
Präg, Patrick and Alexi Gugushvili, 2020. 'Intergenerational Social Mobility and Self-Rated Health in Europe.' SocArXiv doi: 10.31235/osf.io/5tk4z.

— , 2021. 'Replication materials to: Subjective Social Mobility and Health in Germany.' Open Science Framework doi: 10.17605/OSF.IO/J2TQP.

Präg, Patrick, Melinda Mills, and Rafael Wittek, 2016. 'Subjective SocioEconomic Status and Health in Cross-National Comparison.' Social Science \& Medicine 149: 84-92. doi: 10.1016/j.socscimed.2015.11.044.

Präg, Patrick and Lindsay Richards, 2019. 'Intergenerational Social Mobility and Allostatic Load in Great Britain.' Journal of Epidemiology and Community Health 73(2): 100-105. doi: 10.1136/jech-2017-210171.

Schmidt-Catran, Alexander W., 2011. 'The Experience of Social Mobility and the Formation of Attitudes toward Redistribution.' GK Soclife Working Paper Series 6/2011.

Segura, Denise A., 1989. 'Chicana and Mexican Immigrant Women at Work. The Impact of Class, Race, and Gender on Occupational Mobility.' Gender and Society 3(1): 37-52. doi: 10.1177/089124389003001003.

Snyder-Mackler, Noah, Joseph Robert Burger, Lauren Gaydosh, Daniel W. Belsky, Grace A. Noppert, Fernando A. Campos, Alessandro Bartolomucci, Yang Claire Yang, Allison E. Aiello, Angela O'Rand, Kathleen Mullan Harris, Carol A. Shively, Susan C. Alberts, and Jenny Tung, 2020. 'Social Determinants of Health and Survival in Humans and Other Animals.' Science 368(6493): eaax9553. doi: 10.1126/science.aax9553.

Song, Xi, Catherine G. Massey, Karen A. Rolf, Joseph P. Ferrie, Jonathan L. Rothbaum, and Yu Xie, 2020. 'Long-Term Decline in Intergenerational Mobility in the United States since the 1850's.' Proceedings of the National Academy of Sciences 117(1): 251-258. doi: 10.1073/pnas.1905094116.

Sorokin, Pitrim A., 1927. Social Mobility. New York: Harper \& Row.

Stawarz, Nico and Michael Müller, 2020. 'Concerns Regarding Immigration in Germany. How Subjective Fears, Becoming Unemployed, and Social 
Mobility Change Anti-Immigrant Attitudes.' European Societies 22(3): 293-316. doi: 10.1080/14616696.2019.1690159.

Tan, Jacinth J. X., Michael W. Kraus, Nichelle C. Carpenter, and Nancy E. Adler, 2020. 'The Association between Objective and Subjective Socioeconomic Status and Subjective Wellbeing. A Meta-Analytic Review.' Psychological Bulletin 146(11): 970-1020. doi: 10.1037/bul0000258.

Tiffin, Paul A., Mark S. Pearce, and Louise Parker, 2005. 'Social Mobility over the Life Course and Self-Reported Mental Health at Age 50.' Journal of Epidemiology and Community Health 59(10): 870-872. doi: 10.1136/jech.2005.035246.

Van der Waal, Jeroen, Stijn Daenekindt, and Willem de Koster, 2017. 'Statistical Challenges in Modeling the Health Consequences of Social Mobility. The Need for Diagonal Reference Models.' International Journal of Public Health 62(9): 1029-1037. doi: 10.1007/s00038-017-1018-x.

Venkataramani, Atheendar S., Paula Chatterjee, Ichiro Kawachi, and Alexander C. Tsai, 2015. 'Economic Opportunity, Health Behaviors, and Mortality in the United States.' American Journal of Public Health 106(3): 478-484. doi: 10.2105/AJPH.2015.302941.

Venkataramani, Atheendar S., Rourke O'Brien, Gregory L. Whitehorn, and Alexander C. Tsai, 2020. 'Economic Influences on Population Health in the United States. Toward Policymaking Driven by Data and Evidence.' Plos Medicine 17(9): 1-17. doi: 10.1371/journal.pmed.1003319.

Wilkinson, Richard G. and Kate E. Pickett, 2018. The Inner Level. How More Equal Societies Reduce Stress, Restore Sanity, and Improve Everyone's Wellbeing. London: Allen Lane.

Zajacova, Anna, Hanna Grol-Prokopczyk, and Zachary Zimmer, 2021. 'Pain Trends among American Adults, 2002-2018. Patterns, Disparities, and Correlates.' Demography 58(2): 711-738. doi: 10.1215/00703370-8977691. 
Zang, Emma and Nan Dirk de Graaf, 2016. 'Frustrated Achievers or Satisfied Losers? Inter- and Intragenerational Social Mobility and Happiness in China.' Sociological Science 3: 779-800. doi: 10.15195/v3.a33.

Zhao, Yizhang and Yaojun Li, 2019. 'Differential Acculturation. A Study of Wellbeing Differences in Intergenerational Social Mobility between Rural and Urban China.' Sociology 53(4): 724-743. doi: $10.1177 / 0038038518818405$.

Zhao, Yizhang, Yaojun Li, Anthony Heath, and Nick Shryane, 2017. 'Interand Intra-Generational Social Mobility Effects on Subjective Wellbeing. Evidence from Mainland China.' Research in Social Stratification and Mobility 48: 54-66. doi: 10.1016/j.rssm.2017.02.002. 


\section{Supplementary Materials}

These supplementary materials to the manuscript 'Subjective social mobility and health in Germany' report the Tables underlying the Figures of the main text as well as robustness checks, specifically comparing the study sample to the full sample, controlling for age-squared, controlling for education, controlling for labor market status, using weights, and using ordered logit models.

\section{Contents}

$\begin{array}{ll}\text { Supplementary Materials } & \text { A-1 }\end{array}$

Additional tables $\quad$ A-4

Table A1: Descriptive statistics, $N=1,012 \ldots \ldots$. . . . . . A-4

Table A2: Health outcomes regressed on objective mobility trajectories, OLS regression, $N=1,012 \ldots \ldots \ldots$. . . . . . . .

Table A3: Health outcomes regressed on subjective mobility and objective mobility trajectories, OLS regression, $N=1,012$. . . A-6

Table A4: Health outcomes regressed on interaction of objective and subjective mobility, OLS regression, $N=1,012 \ldots \ldots$. A-7

$\begin{array}{ll}\text { Robustness checks } & \text { A-8 }\end{array}$

Does the analytical sample differ from the excluded sample? . . . . A-8

Figure A1: Comparison between analytical sample and other cases for the outcome variables (Panel $A$ ) and respondent's and father's ISEI $($ Panel $B) \ldots$. . . . . . A-8

Controlling for age squared . . . . . . . . . . . . . . . . . A-9

Table A5: Health outcomes regressed on objective mobility trajectories, OLS regression, controlling for age-squared, $N=1,012 \ldots \ldots \ldots \ldots \ldots \ldots$. . . . . . . . . . . . . .

Table A6: Health outcomes regressed on subjective mobility and objective mobility trajectories, OLS regression, controlling for age-squared $N=1,012$. . . . . . . . . A-10 
Table A7: Health outcomes regressed on interaction of objective and subjective mobility, OLS regression, controlling for age-squared, $N=1,012 \ldots \ldots$. . . . . . A-11

Controlling for education . . . . . . . . . . . . . . . . . . . . A-12

Table A8: Health outcomes regressed on objective mobility trajectories, OLS regression, controlling for education, $N=1,010 \ldots \ldots \ldots \ldots \ldots \ldots$. . . . . . . . . . . . . . . .

Table A9: Health outcomes regressed on subjective mobility and objective mobility trajectories, OLS regression, controlling for education, $N=1,010$. . . . . . . . . A-13

Table A10: Health outcomes regressed on interaction of objective and subjective mobility, OLS regression, controlling for education, $N=1,010 \ldots \ldots$. . . . . A-14

Controlling for labor market status . . . . . . . . . . . . . . A-15

Table A11: Health outcomes regressed on objective mobility trajectories, OLS regression, controlling for labor market status, $N=1,012 \ldots \ldots \ldots$. . . . . . . . . . . . .

Table A12: Health outcomes regressed on subjective mobility and objective mobility trajectories, OLS regression, controlling for labor market status, $N=1,012$. . . . . A-16

Table A13: Health outcomes regressed on interaction of objective and subjective mobility, OLS regression, controlling for labor market status, $N=1,012$. . . . . . . A-17

OLS regression with weights . . . . . . . . . . A-18

Table A14: Health outcomes regressed on objective mobility trajectories, OLS regression, weighted analysis, $N=1,012$.A-18

Table A15: Health outcomes regressed on subjective mobility and objective mobility trajectories, OLS regression,

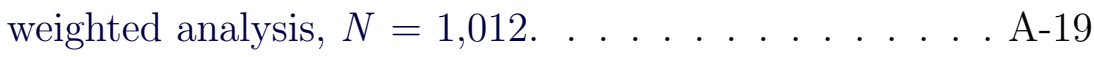

Table A16: Health outcomes regressed on interaction of objective and subjective mobility, OLS regression, weighted analysis, $N=1,012 \ldots \ldots \ldots \ldots$ A $\ldots \ldots$

Ordered logit models . . . . . . . . . . . . . . . . . . . . . A-21 
Table A17: Health outcomes regressed on objective mobility trajectories, ordered logit models, logit coefficients,

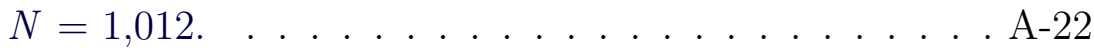

Table A18: Health outcomes regressed on subjective mobility and objective mobility trajectories, ordered logit models, logit coefficients, $N=1,012 \ldots \ldots \ldots \ldots$. . A-23

Table A19: Health outcomes regressed on interaction of objective and subjective mobility, ordered logit models, logit coefficients, $N=1,012 \ldots \ldots \ldots$. . . . . A-24 


\section{Additional tables}

Table A1: Descriptive statistics, $N=1,012$

\begin{tabular}{|c|c|c|c|c|}
\hline & Proportion/Mean & SD & Min. & Max. \\
\hline Self-rated health & 2.54 & 1.04 & 0 & 4 \\
\hline Life satisfaction & 7.27 & 1.88 & 0 & 10 \\
\hline Physical pain & 1.04 & 1.19 & 0 & 4 \\
\hline Depression & 1.31 & 1.07 & 0 & 4 \\
\hline Loneliness & 0.63 & 0.97 & 0 & 4 \\
\hline \multicolumn{5}{|l|}{ Subjective social mobility: } \\
\hline (Much) lower status & 0.23 & & 0 & 1 \\
\hline About equal & 0.38 & & 0 & 1 \\
\hline (Much) higher status & 0.39 & & 0 & 1 \\
\hline \multicolumn{5}{|l|}{ Objective social mobility: } \\
\hline Downwardly mobile & 0.26 & & 0 & 1 \\
\hline Stable & 0.49 & & 0 & 1 \\
\hline Upwardly mobile & 0.26 & & 0 & 1 \\
\hline \multicolumn{5}{|c|}{ Objective mobility trajectory: } \\
\hline Stably low & 0.12 & & 0 & 1 \\
\hline Low to medium & 0.07 & & 0 & 1 \\
\hline Low to high & 0.06 & & 0 & 1 \\
\hline Medium to low & 0.12 & & 0 & 1 \\
\hline Stably medium & 0.16 & & 0 & 1 \\
\hline Medium to high & 0.12 & & 0 & 1 \\
\hline High to low & 0.04 & & 0 & 1 \\
\hline High to medium & 0.09 & & 0 & 1 \\
\hline Stably high & 0.20 & & 0 & 1 \\
\hline Respondent's ISEI & 44.49 & 15.59 & 16 & 90 \\
\hline Father's ISEI & 39.92 & 15.81 & 16 & 90 \\
\hline Age & 50.07 & 16.36 & 19 & 98 \\
\hline Female respondents & 0.48 & & 0 & 1 \\
\hline \multicolumn{5}{|l|}{ Marital status: } \\
\hline Married & 0.61 & & 0 & 1 \\
\hline Widowed/divorced & 0.16 & & 0 & 1 \\
\hline Never married & 0.23 & & 0 & 1 \\
\hline Eastern German & 0.32 & & 0 & 1 \\
\hline$N$ & 1,012 & & & \\
\hline
\end{tabular}

Note: SD: Standard deviation. 
Table A2: Health outcomes regressed on objective mobility trajectories, OLS regression, $N=1,012$. Selected coefficients also presented in Figure 3A in the main text.

\begin{tabular}{|c|c|c|c|c|c|}
\hline & $\begin{array}{c}(1) \\
\text { SRH }\end{array}$ & $\begin{array}{c}(2) \\
\text { Life sat. }\end{array}$ & $\begin{array}{l}(3) \\
\text { Pain }\end{array}$ & $\begin{array}{c}(4) \\
\text { Depression }\end{array}$ & $\begin{array}{c}(5) \\
\text { Loneliness }\end{array}$ \\
\hline \multicolumn{6}{|c|}{ Objective mobility trajectory (ref. stably medium) } \\
\hline \multirow[t]{2}{*}{ Stably low } & -.20 & -.40 & $.47^{* * *}$ & .17 & .16 \\
\hline & $(.12)$ & $(.22)$ & $(.14)$ & $(.13)$ & $(.12)$ \\
\hline \multirow[t]{2}{*}{ Low to medium } & -.24 & -.03 & $.36^{*}$ & .23 & .11 \\
\hline & $(.13)$ & $(.25)$ & $(.16)$ & $(.15)$ & $(.13)$ \\
\hline \multirow[t]{2}{*}{ Low to high } & -.14 & -.01 & .15 & .08 & -.02 \\
\hline & $(.14)$ & $(.27)$ & $(.17)$ & $(.16)$ & $(.14)$ \\
\hline \multirow[t]{2}{*}{ Medium to low } & $-.31^{* *}$ & -.00 & $.39^{* *}$ & .09 & -.06 \\
\hline & (.11) & $(.22)$ & $(.14)$ & $(.12)$ & (.11) \\
\hline \multirow[t]{2}{*}{ Medium to high } & .15 & $.50^{*}$ & -.15 & -.07 & -.11 \\
\hline & $(.11)$ & $(.22)$ & $(.14)$ & $(.13)$ & $(.11)$ \\
\hline \multirow[t]{2}{*}{ High to low } & -.03 & -.19 & .01 & -.04 & .22 \\
\hline & $(.16)$ & $(.31)$ & $(.19)$ & $(.18)$ & $(.16)$ \\
\hline \multirow[t]{2}{*}{ High to medium } & .12 & .29 & .03 & -.18 & -.07 \\
\hline & $(.13)$ & $(.24)$ & $(.15)$ & $(.14)$ & $(.12)$ \\
\hline \multirow[t]{2}{*}{ Stably high } & $.27^{* *}$ & $.51^{* *}$ & $-.31^{*}$ & $-.31^{* *}$ & -.17 \\
\hline & $(.10)$ & $(.19)$ & $(.12)$ & $(.11)$ & $(.10)$ \\
\hline \multicolumn{6}{|l|}{ Control variables } \\
\hline \multirow[t]{2}{*}{ Age } & $-.02^{* * *}$ & .00 & $.01^{* * *}$ & $-.01^{*}$ & .00 \\
\hline & $(.00)$ & $(.00)$ & $(.00)$ & $(.00)$ & $(.00)$ \\
\hline \multirow[t]{2}{*}{ Female sex (ref. male) } & -.09 & .05 & $.17^{*}$ & $.23^{* * *}$ & .06 \\
\hline & $(.06)$ & $(.12)$ & $(.07)$ & $(.07)$ & $(.06)$ \\
\hline \multicolumn{6}{|l|}{ Marital status (ref. married) } \\
\hline \multirow[t]{2}{*}{ Widowed/divorced } & -.07 & $-.70^{* * *}$ & $.21^{*}$ & .06 & $.56^{* * *}$ \\
\hline & $(.09)$ & $(.17)$ & $(.10)$ & $(.10)$ & $(.09)$ \\
\hline \multirow[t]{2}{*}{ Never married } & -.15 & $-.40^{*}$ & .08 & .18 & $.19^{*}$ \\
\hline & $(.08)$ & $(.16)$ & $(.10)$ & $(.09)$ & $(.08)$ \\
\hline \multirow[t]{2}{*}{ East Germany (ref. West) } & -.09 & $-.57^{* * *}$ & -.01 & .02 & -.03 \\
\hline & $(.07)$ & $(.13)$ & $(.08)$ & $(.07)$ & $(.06)$ \\
\hline \multirow[t]{2}{*}{ Constant } & $3.75^{* * *}$ & $7.49^{* * *}$ & $.34^{*}$ & $1.47^{* * *}$ & $.38^{* *}$ \\
\hline & $(.15)$ & $(.28)$ & $(.18)$ & $(.16)$ & $(.14)$ \\
\hline$N$ & 1,012 & 1,012 & 1,012 & 1,012 & 1,012 \\
\hline Avg. outcome (SD) & $2.55(1.06)$ & $7.27(1.92)$ & $1.05(1.20)$ & $1.31(1.07)$ & $.66(.97)$ \\
\hline R-squared & .16 & .07 & .09 & .05 & .06 \\
\hline
\end{tabular}

Notes: SE's in parentheses. SRH: Self-rated health, Life sat.: Life satisfaction, SD: Standard deviation. ${ }^{*} \mathrm{p}<0.05,{ }^{* *} \mathrm{p}<0.01,{ }^{* * *} \mathrm{p}<0.001$ 
Table A3: Health outcomes regressed on subjective mobility and objective mobility trajectories, OLS regression, $N=1,012$. Selected coefficients also presented in Figure 3B in the main text.

\begin{tabular}{|c|c|c|c|c|c|c|c|c|c|c|}
\hline & $\begin{array}{c}(1) \\
\text { SRH }\end{array}$ & $\begin{array}{c}\stackrel{(2)}{ } \\
\text { SRH }\end{array}$ & $\begin{array}{c}(3) \\
\text { Life sat. }\end{array}$ & $\begin{array}{c}(4) \\
\text { Life sat. }\end{array}$ & $\begin{array}{l}\text { (5) } \\
\text { Pain }\end{array}$ & $\begin{array}{c}(6) \\
\text { Pain }\end{array}$ & $\begin{array}{c}(7) \\
\text { Depression }\end{array}$ & $\begin{array}{c}(8) \\
\text { Depression }\end{array}$ & $\begin{array}{c}(9) \\
\text { Loneliness }\end{array}$ & $\begin{array}{c}(10) \\
\text { Loneliness }\end{array}$ \\
\hline \multicolumn{11}{|c|}{ Subjective status mobility (ref. about equal) } \\
\hline (Much) lower st & $\begin{array}{l}-.07 \\
(.08)\end{array}$ & $\begin{array}{l}-.10 \\
(.08)\end{array}$ & $\begin{array}{l}-.04 \\
(.16)\end{array}$ & $\begin{array}{l}-.08 \\
(.16)\end{array}$ & $\begin{array}{l}.06 \\
(.10)\end{array}$ & $\begin{array}{l}.08 \\
.(10)\end{array}$ & $\begin{array}{l}.03 \\
(.09)\end{array}$ & $\begin{array}{l}.08 \\
.09)\end{array}$ & $\begin{array}{l}.16^{*} \\
(.08)\end{array}$ & $\begin{array}{l}.17^{*} \\
(.08)\end{array}$ \\
\hline (Much) higher status & $\begin{array}{l}.06 \\
(.07)\end{array}$ & $\begin{array}{l}.06 \\
(.07)\end{array}$ & $\begin{array}{l}.40^{* *} \\
(.13)\end{array}$ & $\begin{array}{l}.40^{* *} \\
(.13)\end{array}$ & $\begin{array}{l}-.12 \\
(.08)\end{array}$ & $\begin{array}{l}-.10 \\
(.08)\end{array}$ & $\begin{array}{l}-.08 \\
(.08)\end{array}$ & $\begin{array}{l}-.10 \\
(.08)\end{array}$ & $\begin{array}{l}.03 \\
. .07)\end{array}$ & $\begin{array}{l}.03 \\
(.07)\end{array}$ \\
\hline \multicolumn{11}{|c|}{ Objective mobility trajectory (ref. stably medium) } \\
\hline \multicolumn{2}{|l|}{ Stably low } & $\begin{array}{l}-.19 \\
(.12)\end{array}$ & & $\begin{array}{l}-.37 \\
(.22)\end{array}$ & & $\begin{array}{l}.46^{* *} \\
(.14)\end{array}$ & & $\begin{array}{l}.16 \\
(.13)\end{array}$ & & $\begin{array}{l}.16 \\
(.12)\end{array}$ \\
\hline \multicolumn{2}{|l|}{ Low to medium } & $\begin{array}{r}-.25 \\
(13)\end{array}$ & & $\begin{array}{l}-.05 \\
(.25)\end{array}$ & & $\begin{array}{l}.37^{*} \\
(16)\end{array}$ & & $\begin{array}{r}.24 \\
.15\end{array}$ & & $\begin{array}{l}.12 \\
.13)\end{array}$ \\
\hline \multirow{2}{*}{\multicolumn{2}{|c|}{ Low to high }} & -.16 & & -.12 & & .18 & & .11 & & -.02 \\
\hline & & $(.15)$ & & $(.27)$ & & $(.17)$ & & $(.16)$ & & $(.14)$ \\
\hline \multicolumn{2}{|l|}{ Medium to low } & $\begin{array}{l}-.28^{*} \\
(.12)\end{array}$ & & $\begin{array}{l}.09 \\
.222\end{array}$ & & $\begin{array}{r}.35^{*} \\
(.14)\end{array}$ & & $\begin{array}{l}.06 \\
(.13)\end{array}$ & & $\begin{array}{l}. .08 \\
(.11)\end{array}$ \\
\hline \multirow{2}{*}{\multicolumn{2}{|c|}{ Medium to high }} & .13 & & .40 & & -.12 & & -.04 & & $\begin{array}{l}.09 \\
-.09\end{array}$ \\
\hline & & (.12) & & $(.22)$ & & (.14) & & (.13) & & $(.11)$ \\
\hline \multirow{2}{*}{\multicolumn{2}{|c|}{ High to low }} & .02 & & -.04 & & -.05 & & -.10 & & .17 \\
\hline & & (.17) & & $(.31)$ & & $(.20)$ & & (.18) & & (.16) \\
\hline \multicolumn{2}{|l|}{ High to medium } & $\begin{array}{l}.16 \\
(13)\end{array}$ & & $\begin{array}{l}.43 \\
(24)\end{array}$ & & $\begin{array}{r}-.03 \\
(15)\end{array}$ & & $\begin{array}{r}-.24 \\
(14)\end{array}$ & & $\begin{array}{r}-.11 \\
(13)\end{array}$ \\
\hline \multirow{2}{*}{\multicolumn{2}{|c|}{ Stably high }} & $.28^{* *}$ & & $.56^{* *}$ & & $-.33^{*+}$ & & $-.33^{* *}$ & & $\begin{array}{l}.119) \\
-.19\end{array}$ \\
\hline & & $(.10)$ & & (.19) & & $(.12)$ & & $(.11)$ & & $(.10)$ \\
\hline \multicolumn{11}{|l|}{ Control variables } \\
\hline Age & $\begin{array}{l}-.02^{* * * *} \\
(00)\end{array}$ & $\begin{array}{l}-.02^{2 * * *} \\
(00)\end{array}$ & $\begin{array}{l}-.00 \\
(000)\end{array}$ & $\begin{array}{l}-.00 \\
(000\end{array}$ & $\begin{array}{l}.01^{* * *} \\
(00)\end{array}$ & $.01^{1 * * *}$ & $\begin{array}{l}-.01^{*} \\
(000\end{array}$ & $\begin{array}{l}-.01^{*} \\
(00)\end{array}$ & $\begin{array}{l}.00 \\
.00)\end{array}$ & .00 \\
\hline Female sex (ref. male) & $\begin{array}{l}-.06 \\
. .06)\end{array}$ & $\begin{array}{l}. .06 \\
(.06)\end{array}$ & $\begin{array}{l}.13 \\
(.12)\end{array}$ & $\begin{array}{l}.12 \\
(.12)\end{array}$ & $\begin{array}{l}.12 \\
(.08)\end{array}$ & $\begin{array}{l}.14 \\
(.08)\end{array}$ & $\begin{array}{l}.21^{* *} \\
(.07)\end{array}$ & $\begin{array}{l}.20^{* *} \\
(.07)\end{array}$ & $\begin{array}{l}.04 \\
(.06)\end{array}$ & $\begin{array}{l}.04 \\
(.06)\end{array}$ \\
\hline \multicolumn{11}{|l|}{ Marital status (ref. married) } \\
\hline Widowed/divorced & $\begin{array}{l}-.06 \\
(.09)\end{array}$ & $\begin{array}{l}-.06 \\
(.09)\end{array}$ & $\begin{array}{l}-.70^{+* * *} \\
(.17)\end{array}$ & $\begin{array}{l}-.69^{* * * *} \\
(.17)\end{array}$ & $\begin{array}{l}.21^{*} \\
(.11)\end{array}$ & $\begin{array}{l}.20 \\
(.10)\end{array}$ & $\begin{array}{l}.05 \\
(.10)\end{array}$ & $\begin{array}{l}.05 \\
(.10)\end{array}$ & $\begin{array}{l}.55^{*+*} \\
(.09)\end{array}$ & $\begin{array}{l}.55^{* * *} \\
(.09)\end{array}$ \\
\hline \multirow[t]{2}{*}{ Never married } & -.13 & -.14 & $-.37^{*}$ & $-39^{*}$ & .06 & .08 & .16 & .17 & $.17^{*}$ & $.18^{*}$ \\
\hline & $(.09)$ & $(.08)$ & $(.16)$ & $(.16)$ & $(.10)$ & $(.10)$ & $(.09)$ & $(.09)$ & $(.08)$ & $(.08)$ \\
\hline \multirow[t]{2}{*}{ East Germany (ref. West) } & -.12 & -.09 & $-.59^{+* * *}$ & $-.54^{* * *}$ & .03 & -.01 & .05 & .01 & -.00 & -.02 \\
\hline & $(.07)$ & $(.07)$ & $(.13)$ & $(.12)$ & $(.08)$ & $(.08)$ & $(.07)$ & $(.07)$ & $(.06)$ & $(.07)$ \\
\hline Constant & $\begin{array}{c}3.76^{* * * *} \\
(.14)\end{array}$ & $\begin{array}{c}3.73^{* * *} \\
(.15)\end{array}$ & $\begin{array}{c}7.56^{* * *} \\
(.25)\end{array}$ & $\begin{array}{c}7.31^{* * *} \\
(.29)\end{array}$ & $\begin{array}{l}.38^{*} \\
(.16)\end{array}$ & $\begin{array}{l}.38^{*} \\
(.18)\end{array}$ & $\begin{array}{c}1.42^{* * *} \\
(.15)\end{array}$ & $\begin{array}{c}1.51^{* * *} \\
(.17)\end{array}$ & $\begin{array}{l}.28^{*} \\
(.13)\end{array}$ & $\begin{array}{l}.34^{*} \\
(.15)\end{array}$ \\
\hline$N$ & 1,012 & 1,012 & 1,012 & 1,012 & 1,012 & 1,012 & 1,012 & 1,012 & 1,012 & 1,012 \\
\hline Avg. outcome (SD) & $2.55(1.06)$ & $2.55(1.06)$ & $7.27(1.92)$ & $7.27(1.92)$ & $1.05(1.20)$ & $1.05(1.20)$ & $1.31(1.07)$ & $1.31(1.07)$ & $.66(.97)$ & $.66(.97)$ \\
\hline R-squared & .12 & .16 & .06 & .08 & .04 & .09 & .03 & .05 & .05 & .07 \\
\hline
\end{tabular}

Notes: SE's in parentheses. SRH: Self-rated health, Life sat.: Life satisfaction, SD: Standard deviation. ${ }^{*} \mathrm{p}<0.05,{ }^{* *} \mathrm{p}<0.01,{ }^{* * *} \mathrm{p}<0.001$ 
Table A4: Health outcomes regressed on interaction of objective and subjective mobility, OLS regression, $N=1,012$. Predictions based on these models presented in Figure 4 in the main text.

\begin{tabular}{|c|c|c|c|c|c|}
\hline & $\begin{array}{c}(1) \\
\text { SRH }\end{array}$ & $\begin{array}{c}(2) \\
\text { Life sat. }\end{array}$ & $\begin{array}{c}(3) \\
\text { Pain }\end{array}$ & $\begin{array}{c}(4) \\
\text { Depression }\end{array}$ & $\begin{array}{c}(5) \\
\text { Loneliness }\end{array}$ \\
\hline \multicolumn{6}{|l|}{ Subjective status mobility (ref. about equal) } \\
\hline (Much) lower status & $\begin{array}{l}.15 \\
(.12)\end{array}$ & $\begin{array}{l}.27 \\
(.22)\end{array}$ & $\begin{array}{l}-.11 \\
(.14)\end{array}$ & $\begin{array}{l}-.01 \\
(.13)\end{array}$ & $\begin{array}{l}.12 \\
(.12)\end{array}$ \\
\hline (Much) higher status & $\begin{array}{l}.03 \\
(.10)\end{array}$ & $\begin{array}{l}.58^{* *} \\
(.19)\end{array}$ & $\begin{array}{l}-.03 \\
(.12)\end{array}$ & $\begin{array}{l}.08 \\
(.11)\end{array}$ & $\begin{array}{l}.05 \\
(.10)\end{array}$ \\
\hline \multicolumn{6}{|l|}{ Objective status mobility (ref. immobile) } \\
\hline Downwardly mobile & $\begin{array}{l}-.01 \\
(.12)\end{array}$ & $\begin{array}{l}.25 \\
(.22)\end{array}$ & $\begin{array}{l}.20 \\
(.14)\end{array}$ & $\begin{array}{l}.04 \\
(.13)\end{array}$ & $\begin{array}{l}-.06 \\
(.11)\end{array}$ \\
\hline Upwardly mobile & $\begin{array}{l}-.16 \\
(.13)\end{array}$ & $\begin{array}{l}.33 \\
(.24)\end{array}$ & $\begin{array}{l}.10 \\
(.15)\end{array}$ & $\begin{array}{l}.46^{* *} \\
(.14)\end{array}$ & $\begin{array}{l}.10 \\
(.13)\end{array}$ \\
\hline \multicolumn{6}{|l|}{ Interaction terms } \\
\hline (Much) lower status $\times$ Downwardly mobile & $\begin{array}{l}-.37^{*} \\
(.18)\end{array}$ & $\begin{array}{l}-.55 \\
(.34)\end{array}$ & $\begin{array}{l}.08 \\
(.21)\end{array}$ & $\begin{array}{l}.16 \\
(.19)\end{array}$ & $\begin{array}{l}.13 \\
(.17)\end{array}$ \\
\hline (Much) lower status $\times$ Upwardly mobile & $\begin{array}{l}-.73^{* *} \\
(.27)\end{array}$ & $\begin{array}{l}-.59 \\
(.50)\end{array}$ & $\begin{array}{c}1.19^{* * *} \\
(.32)\end{array}$ & $\begin{array}{l}.16 \\
(.29)\end{array}$ & $\begin{array}{l}.06 \\
(.26)\end{array}$ \\
\hline (Much) higher status $\times$ Downwardly mobile & $\begin{array}{l}-.21 \\
(.19)\end{array}$ & $\begin{array}{l}-.17 \\
(.37)\end{array}$ & $\begin{array}{l}.03 \\
(.23)\end{array}$ & $\begin{array}{l}-.12 \\
(.21)\end{array}$ & $\begin{array}{l}.09 \\
(.19)\end{array}$ \\
\hline (Much) higher status $\times$ Upwardly mobile & $\begin{array}{l}.23 \\
(.17)\end{array}$ & $\begin{array}{l}-.47 \\
(.31)\end{array}$ & $\begin{array}{l}-.19 \\
(.20)\end{array}$ & $\begin{array}{l}-.57^{* *} \\
(.18)\end{array}$ & $\begin{array}{l}-.15 \\
(.16)\end{array}$ \\
\hline \multicolumn{6}{|l|}{ Control variables } \\
\hline Age & $\begin{array}{c}-.02^{* * *} \\
(.00)\end{array}$ & $\begin{array}{l}-.00 \\
(.00)\end{array}$ & $\begin{array}{l}.01^{* * *} \\
(.00)\end{array}$ & $\begin{array}{l}-.01^{*} \\
(.00)\end{array}$ & $\begin{array}{l}.00 \\
(.00)\end{array}$ \\
\hline Female sex (ref. male) & $\begin{array}{l}-.05 \\
(.06)\end{array}$ & $\begin{array}{l}.12 \\
(.12)\end{array}$ & $\begin{array}{l}.12 \\
(.08)\end{array}$ & $\begin{array}{l}.19^{* *} \\
(.07)\end{array}$ & $\begin{array}{l}.03 \\
(.06)\end{array}$ \\
\hline \multicolumn{6}{|l|}{ Marital status (ref. married) } \\
\hline Widowed/divorced & $\begin{array}{l}-.08 \\
(.09)\end{array}$ & $\begin{array}{c}-.70^{* * *} \\
(.17)\end{array}$ & $\begin{array}{l}.23^{*} \\
(.11)\end{array}$ & $\begin{array}{l}.07 \\
(.10)\end{array}$ & $\begin{array}{l}.56^{* * *} \\
(.09)\end{array}$ \\
\hline Never married & $\begin{array}{l}-.12 \\
(.09)\end{array}$ & $\begin{array}{l}-.38^{*} \\
(.16)\end{array}$ & $\begin{array}{l}.06 \\
(.10)\end{array}$ & $\begin{array}{l}.15 \\
(.09)\end{array}$ & $\begin{array}{l}.17^{*} \\
(.08)\end{array}$ \\
\hline East Germany (ref. West) & $\begin{array}{l}-.12 \\
(.07)\end{array}$ & $\begin{array}{c}-.59^{* * *} \\
(.13)\end{array}$ & $\begin{array}{l}.04 \\
(.08)\end{array}$ & $\begin{array}{l}.05 \\
(.07)\end{array}$ & $\begin{array}{l}-.00 \\
(.06)\end{array}$ \\
\hline Constant & $\begin{array}{c}3.79^{* * *} \\
(.14)\end{array}$ & $\begin{array}{c}7.44^{* * *} \\
(.27)\end{array}$ & $\begin{array}{c}.33 \\
(.17)\end{array}$ & $\begin{array}{c}1.34^{* * *} \\
(.16)\end{array}$ & $\begin{array}{l}.28^{*} \\
(.14)\end{array}$ \\
\hline$N$ & 1,012 & 1,012 & 1,012 & 1,012 & 1,012 \\
\hline Avg. outcome (SD) & $2.55(1.06)$ & $7.27(1.92)$ & $1.05(1.20)$ & $1.31(1.07)$ & $.66(.97)$ \\
\hline R-squared & .14 & .06 & .06 & .04 & .06 \\
\hline
\end{tabular}

Notes: SE's in parentheses. SRH: Self-rated health, Life sat.: Life satisfaction, SD: Standard deviation. ${ }^{*} \mathrm{p}<0.05,{ }^{* *} \mathrm{p}<0.01,{ }^{* * *} \mathrm{p}<0.001$ 


\section{Robustness checks}

\section{Does the analytical sample differ from the excluded sample?}

As mentioned in the data description, we restrict our analyses to one randomly chosen half of the sample, as only half of respondents answered the key question about subjective social mobility. Figure A1 shows that the two groups hardly differ on the outcome variables and the objective social position variables, indicating that the randomization when distributing questionnaires worked well.

A
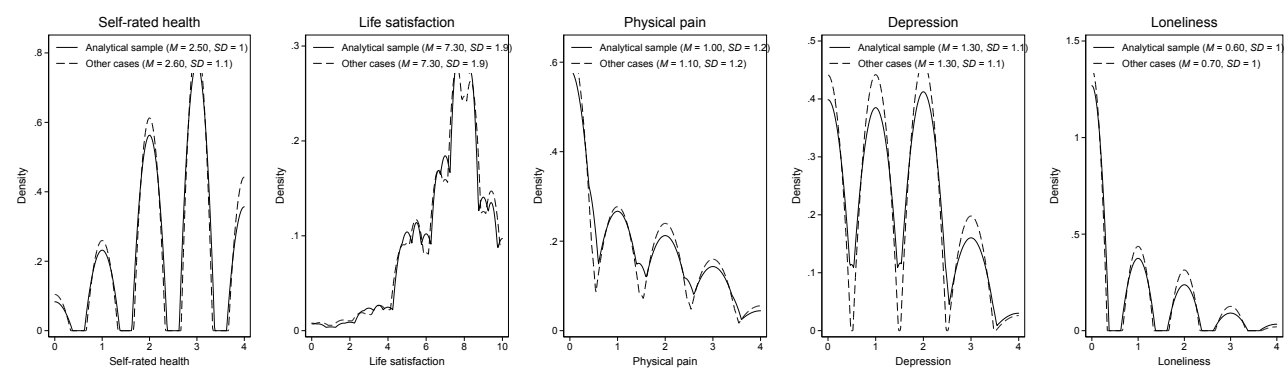

B
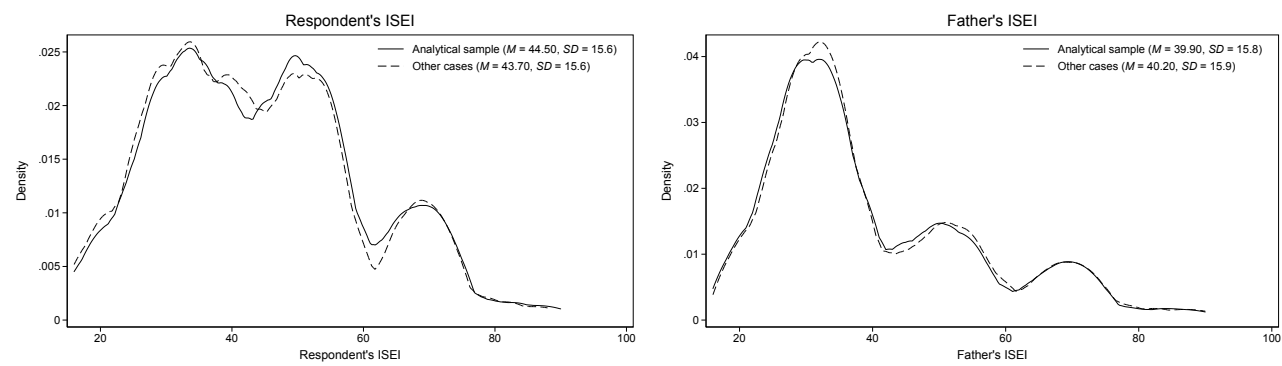

Figure A1: Analytical sample and excluded cases do not differ to a meaningful extent. Comparison between analytical sample and other cases for the outcome variables (Panel $A$ ) and respondent's and father's ISEI (Panel B) 


\section{Controlling for age squared}

Table A5: Health outcomes regressed on objective mobility trajectories, OLS regression, controlling for age-squared, $N=1,012$.

\begin{tabular}{|c|c|c|c|c|c|}
\hline & $\begin{array}{c}(1) \\
\text { SRH }\end{array}$ & $\begin{array}{c}(2) \\
\text { Life sat. }\end{array}$ & $\begin{array}{l}(3) \\
\text { Pain }\end{array}$ & $\begin{array}{c}(4) \\
\text { Depression }\end{array}$ & $\begin{array}{c}(5) \\
\text { Loneliness }\end{array}$ \\
\hline \multicolumn{6}{|c|}{ Objective mobility trajectory (ref. stably medium) } \\
\hline Stably low & $\begin{array}{l}-.20 \\
(.12)\end{array}$ & $\begin{array}{l}-.42 \\
(.22)\end{array}$ & $\begin{array}{l}.45^{* *} \\
(.14)\end{array}$ & $\begin{array}{l}.17 \\
(.13)\end{array}$ & $\begin{array}{l}.16 \\
(.12)\end{array}$ \\
\hline Low to medium & $\begin{array}{l}-.24 \\
(.13)\end{array}$ & $\begin{array}{l}-.03 \\
(.25)\end{array}$ & $\begin{array}{l}.36^{*} \\
(.16)\end{array}$ & $\begin{array}{l}.23 \\
(.15)\end{array}$ & $\begin{array}{l}.11 \\
(.13)\end{array}$ \\
\hline Low to high & $\begin{array}{l}-.14 \\
(.14)\end{array}$ & $\begin{array}{l}.00 \\
(.27)\end{array}$ & $\begin{array}{l}.16 \\
(.17)\end{array}$ & $\begin{array}{l}.08 \\
(.16)\end{array}$ & $\begin{array}{l}-.02 \\
(.14)\end{array}$ \\
\hline Medium to low & $\begin{array}{c}-.31^{* *} \\
(.11)\end{array}$ & $\begin{array}{l}-.03 \\
(.22)\end{array}$ & $\begin{array}{l}.36^{* *} \\
(.14)\end{array}$ & $\begin{array}{l}.08 \\
(.13)\end{array}$ & $\begin{array}{l}-.06 \\
(.11)\end{array}$ \\
\hline Medium to high & $\begin{array}{l}.15 \\
(.11)\end{array}$ & $\begin{array}{l}.49^{*} \\
(.22)\end{array}$ & $\begin{array}{l}-.16 \\
(.14)\end{array}$ & $\begin{array}{l}-.07 \\
(.13)\end{array}$ & $\begin{array}{l}-.11 \\
(.11)\end{array}$ \\
\hline High to low & $\begin{array}{l}-.03 \\
(.16)\end{array}$ & $\begin{array}{l}-.22 \\
(.31)\end{array}$ & $\begin{array}{l}-.01 \\
(.19)\end{array}$ & $\begin{array}{l}-.05 \\
(.18)\end{array}$ & $\begin{array}{l}.23 \\
(.16)\end{array}$ \\
\hline High to medium & $\begin{array}{l}.12 \\
(.13)\end{array}$ & $\begin{array}{l}.30 \\
(.24)\end{array}$ & $\begin{array}{l}.03 \\
(.15)\end{array}$ & $\begin{array}{l}-.18 \\
(.14)\end{array}$ & $\begin{array}{l}-.07 \\
(.12)\end{array}$ \\
\hline Stably high & $\begin{array}{l}.27^{* *} \\
(.10)\end{array}$ & $\begin{array}{l}.52^{* *} \\
(.19)\end{array}$ & $\begin{array}{l}-.30^{*} \\
(.12)\end{array}$ & $\begin{array}{l}-.31^{* *} \\
(.11)\end{array}$ & $\begin{array}{l}-.17 \\
(.10)\end{array}$ \\
\hline \multicolumn{6}{|l|}{ Control variables } \\
\hline Age & $\begin{array}{l}-.02^{*} \\
(.01)\end{array}$ & $\begin{array}{l}-.03 \\
(.02)\end{array}$ & $\begin{array}{l}-.02 \\
(.01)\end{array}$ & $\begin{array}{l}-.02 \\
(.01)\end{array}$ & $\begin{array}{l}.00 \\
(.01)\end{array}$ \\
\hline Age $\times$ Age & $\begin{array}{l}.00 \\
(.00)\end{array}$ & $\begin{array}{l}.00 \\
(.00)\end{array}$ & $\begin{array}{l}.00^{*} \\
(.00)\end{array}$ & $\begin{array}{l}.00 \\
(.00)\end{array}$ & $\begin{array}{l}-.00 \\
(.00)\end{array}$ \\
\hline Female sex (ref. male) & $\begin{array}{l}-.09 \\
(.06)\end{array}$ & $\begin{array}{l}.04 \\
(.12)\end{array}$ & $\begin{array}{l}.16^{*} \\
(.07)\end{array}$ & $\begin{array}{l}.23^{* * *} \\
(.07)\end{array}$ & $\begin{array}{l}.06 \\
(.06)\end{array}$ \\
\hline \multicolumn{6}{|l|}{ Marital status (ref. married) } \\
\hline Widowed/divorced & $\begin{array}{l}-.07 \\
(.09)\end{array}$ & $\begin{array}{c}-.73^{* * *} \\
(.17)\end{array}$ & $\begin{array}{l}.19 \\
(.10)\end{array}$ & $\begin{array}{l}.05 \\
(.10)\end{array}$ & $\begin{array}{l}.56^{* * *} \\
(.09)\end{array}$ \\
\hline Never married & $\begin{array}{l}-.16 \\
(.09)\end{array}$ & $\begin{array}{c}-.50^{* *} \\
(.17)\end{array}$ & $\begin{array}{c}.00 \\
(.11)\end{array}$ & $\begin{array}{c}.15 \\
(.10)\end{array}$ & $\begin{array}{l}.19^{*} \\
(.09)\end{array}$ \\
\hline East Germany (ref. West) & $\begin{array}{l}-.09 \\
(.07)\end{array}$ & $\begin{array}{c}-.56^{* * *} \\
(.13)\end{array}$ & $\begin{array}{l}-.00 \\
(.08)\end{array}$ & $\begin{array}{c}.02 \\
(.07)\end{array}$ & $\begin{array}{l}-.03 \\
(.07)\end{array}$ \\
\hline Constant & $\begin{array}{c}3.82^{* * *} \\
(.32)\end{array}$ & $\begin{array}{c}8.34^{* * *} \\
(.61)\end{array}$ & $\begin{array}{l}1.04^{* *} \\
(.38)\end{array}$ & $\begin{array}{c}1.73^{* * *} \\
(.35)\end{array}$ & $\begin{array}{l}.33 \\
(.32)\end{array}$ \\
\hline$N$ & 1,012 & 1,012 & 1,012 & 1,012 & 1,012 \\
\hline Avg. outcome (SD) & $2.55(1.06)$ & $7.27(1.92)$ & $1.05(1.20)$ & $1.31(1.07)$ & $.66(.97)$ \\
\hline $\begin{array}{l}\text { R-squared } \\
\text { bottomrule }\end{array}$ & .16 & .08 & .09 & .05 & .06 \\
\hline
\end{tabular}

Notes: SE's in parentheses. SRH: Self-rated health, Life sat.: Life satisfaction, SD: Standard deviation. ${ }^{*} \mathrm{p}<0.05,{ }^{* *} \mathrm{p}<0.01,{ }^{* * *} \mathrm{p}<0.001$ 
Table A6: Health outcomes regressed on subjective mobility and objective mobility trajectories, OLS regression, controlling for age-squared $N=1,012$.

\begin{tabular}{|c|c|c|c|c|c|c|c|c|c|c|}
\hline & $\begin{array}{l}(1) \\
\text { SRH }\end{array}$ & $\begin{array}{c}(2) \\
\text { SRH }\end{array}$ & $\begin{array}{c}(3) \\
\text { Life sat. }\end{array}$ & $\begin{array}{c}\text { (4) } \\
\text { Life sat. }\end{array}$ & $\begin{array}{l}\text { (5) } \\
\text { Pain }\end{array}$ & $\begin{array}{l}(6) \\
\text { Pain }\end{array}$ & $\begin{array}{c}(7) \\
\text { Depression }\end{array}$ & $\begin{array}{c}(8) \\
\text { Depression }\end{array}$ & $\begin{array}{c}(9) \\
\text { Loneliness }\end{array}$ & $\begin{array}{c}(10) \\
\text { Loneliness }\end{array}$ \\
\hline \multicolumn{11}{|c|}{ Subjective status mobility (ref. about equal) } \\
\hline (Much) lower status & $\begin{array}{l}-.07 \\
(.08)\end{array}$ & $\begin{array}{l}-.10 \\
(.08)\end{array}$ & $\begin{array}{l}-.03 \\
(.16)\end{array}$ & $\begin{array}{l}-.07 \\
(.16)\end{array}$ & $\begin{array}{l}.07 \\
(.10)\end{array}$ & $\begin{array}{l}.09 \\
(.10)\end{array}$ & $\begin{array}{l}.03 \\
(.09)\end{array}$ & $\begin{array}{c}.08 \\
(.09)\end{array}$ & $\begin{array}{l}.16^{*} \\
(.08)\end{array}$ & $\begin{array}{l}.17^{*} \\
(.08)\end{array}$ \\
\hline (Much) higher status & $\begin{array}{l}.06 \\
(.07)\end{array}$ & $\begin{array}{l}.06 \\
(.07)\end{array}$ & $\begin{array}{l}.41^{* *} \\
(.13)\end{array}$ & $\begin{array}{l}.42^{* *} \\
(.13)\end{array}$ & $\begin{array}{l}-.10 \\
(.08)\end{array}$ & $\begin{array}{l}-.09 \\
(.08)\end{array}$ & $\begin{array}{l}-.07 \\
(.08)\end{array}$ & $\begin{array}{l}-.10 \\
(.08)\end{array}$ & $\begin{array}{l}.03 \\
(.07)\end{array}$ & $\begin{array}{l}.03 \\
(.07)\end{array}$ \\
\hline \multicolumn{11}{|c|}{ Objective mobility trajectory (ref. stably medium) } \\
\hline Stably low & & $\begin{array}{l}-.19 \\
(.12)\end{array}$ & & $\begin{array}{l}-.40 \\
(.22)\end{array}$ & & $\begin{array}{l}.44^{* *} \\
(.14)\end{array}$ & & $\begin{array}{l}.16 \\
(.13)\end{array}$ & & $\begin{array}{l}.16 \\
(.12)\end{array}$ \\
\hline Low to medium & & $\begin{array}{l}-.25 \\
(.13)\end{array}$ & & $\begin{array}{l}-.05 \\
(.25)\end{array}$ & & $\begin{array}{l}.37^{*} \\
(.16)\end{array}$ & & $\begin{array}{l}.24 \\
(.15)\end{array}$ & & $\begin{array}{l}.12 \\
(.13)\end{array}$ \\
\hline Low to high & & $\begin{array}{l}-.16 \\
(.15)\end{array}$ & & $\begin{array}{l}-.10 \\
(.27)\end{array}$ & & $\begin{array}{l}.19 \\
(.17)\end{array}$ & & $\begin{array}{l}.11 \\
(.16)\end{array}$ & & $\begin{array}{l}-.02 \\
(.14)\end{array}$ \\
\hline Medium to low & & $-.28^{*}$ & & .06 & & $\begin{array}{l}.33^{*} \\
(14)\end{array}$ & & $\begin{array}{l}.05 \\
(13)\end{array}$ & & -.08 \\
\hline Medium to high & & $\begin{array}{l}.13 \\
(.12)\end{array}$ & & $\begin{array}{c}.39 \\
(.22)\end{array}$ & & $\begin{array}{l}-.12 \\
(.14)\end{array}$ & & $\begin{array}{l}-.04 \\
(.13)\end{array}$ & & $\begin{array}{l}-.09 \\
(.11)\end{array}$ \\
\hline High to low & & $\begin{array}{l}.02 \\
(.17)\end{array}$ & & $\begin{array}{l}-.07 \\
(.31)\end{array}$ & & $\begin{array}{l}-.07 \\
(.20)\end{array}$ & & $\begin{array}{l}-.11 \\
(.18)\end{array}$ & & $\begin{array}{l}.17 \\
(.16)\end{array}$ \\
\hline High to medium & & $\begin{array}{l}.16 \\
(.13)\end{array}$ & & $\begin{array}{l}.43 \\
(.24)\end{array}$ & & $\begin{array}{l}-.02 \\
(.15)\end{array}$ & & $\begin{array}{l}. .24 \\
(.14)\end{array}$ & & $\begin{array}{l}-.11 \\
(.13)\end{array}$ \\
\hline Stably high & & $\begin{array}{l}.28^{* *} \\
(.10)\end{array}$ & & $\begin{array}{l}.57^{* *} \\
(.19)\end{array}$ & & $\begin{array}{c}-.32^{* *} \\
(.12)\end{array}$ & & $\begin{array}{c}-.33^{* *} \\
(.11)\end{array}$ & & $\begin{array}{l}-.19 \\
(.10)\end{array}$ \\
\hline \multicolumn{11}{|l|}{ Control variables } \\
\hline Age & $\begin{array}{l}-.02 \\
(.01)\end{array}$ & $\begin{array}{l}-.03^{*} \\
(.01)\end{array}$ & $\begin{array}{l}-.03 \\
(.02)\end{array}$ & $\begin{array}{l}-.04 \\
(.02)\end{array}$ & $\begin{array}{l}-.02 \\
(.01)\end{array}$ & $\begin{array}{l}-.02 \\
(.01)\end{array}$ & $\begin{array}{l}-.02 \\
(.01)\end{array}$ & $\begin{array}{l}-.01 \\
(.01)\end{array}$ & $\begin{array}{l}.00 \\
(.01)\end{array}$ & $\begin{array}{l}.00 \\
. .01)\end{array}$ \\
\hline Age $\times$ Age & $\begin{array}{l}-.00 \\
(.00)\end{array}$ & $\begin{array}{l}.00 \\
(.00)\end{array}$ & $\begin{array}{l}.00 \\
(.00)\end{array}$ & $\begin{array}{l}.00 \\
(.00)\end{array}$ & $\begin{array}{l}.00^{*} \\
(.00)\end{array}$ & $\begin{array}{l}.00^{*} \\
(.00)\end{array}$ & $\begin{array}{l}.00 \\
(.00)\end{array}$ & $\begin{array}{l}.00 \\
(.00)\end{array}$ & $\begin{array}{l}.00 \\
(.00)\end{array}$ & $\begin{array}{l}-.00 \\
(.00)\end{array}$ \\
\hline Female sex (ref. male) & $\begin{array}{l}-.06 \\
(.06)\end{array}$ & $\begin{array}{l}-.06 \\
(.06)\end{array}$ & $\begin{array}{l}.12 \\
(.12)\end{array}$ & $\begin{array}{l}.11 \\
(.12)\end{array}$ & $\begin{array}{l}.12 \\
(.08)\end{array}$ & $\begin{array}{l}.13 \\
(.08)\end{array}$ & $\begin{array}{l}.21^{* *} \\
(.07)\end{array}$ & $\begin{array}{l}.20^{* * *} \\
(.07)\end{array}$ & $\begin{array}{l}.03 \\
(.06)\end{array}$ & $\begin{array}{l}.04 \\
(.06)\end{array}$ \\
\hline \multicolumn{11}{|l|}{ Marital status (ref. married) } \\
\hline Widowed/divorced & $\begin{array}{l}-.06 \\
(.09)\end{array}$ & $\begin{array}{l}-.07 \\
(.09)\end{array}$ & $\begin{array}{c}-.72^{+* *} \\
(.17)\end{array}$ & $\begin{array}{c}-.72^{* * *} \\
(.17)\end{array}$ & $\begin{array}{l}.18 \\
(.11)\end{array}$ & $\begin{array}{l}.18 \\
(.10)\end{array}$ & $\begin{array}{c}.04 \\
(.10)\end{array}$ & $\begin{array}{l}.05 \\
(.10)\end{array}$ & $\begin{array}{l}.55^{* * *} \\
(.09)\end{array}$ & $\begin{array}{l}.55^{* * *} \\
(.09)\end{array}$ \\
\hline Never married & $\begin{array}{l}-.12 \\
(.09)\end{array}$ & $\begin{array}{l}-.15 \\
(.09)\end{array}$ & $\begin{array}{l}-.46^{* *} \\
(.17)\end{array}$ & $\begin{array}{l}-.51^{* *} \\
(.17)\end{array}$ & $\begin{array}{l}-.04 \\
(.11)\end{array}$ & $\begin{array}{l}-.00 \\
(.11)\end{array}$ & $\begin{array}{l}.12 \\
(.10)\end{array}$ & $\begin{array}{l}.14 \\
(.10)\end{array}$ & $\begin{array}{l}.17 \\
(.09)\end{array}$ & $\begin{array}{l}.18^{+} \\
(.09)\end{array}$ \\
\hline East Germany (ref. West) & $\begin{array}{l}-.12 \\
(.07)\end{array}$ & $\begin{array}{l}-.09 \\
(.07)\end{array}$ & $\begin{array}{l}-.59^{* * *} \\
(.13)\end{array}$ & $\begin{array}{l}-.53^{* * *} \\
(.12)\end{array}$ & $\begin{array}{l}.04 \\
.08)\end{array}$ & $\begin{array}{l}-.01 \\
(.08)\end{array}$ & $\begin{array}{l}.05 \\
(.07)\end{array}$ & $\begin{array}{l}.02 \\
(.07)\end{array}$ & $\begin{array}{l}-.00 \\
(.06)\end{array}$ & $\begin{array}{l}-.02 \\
(.07)\end{array}$ \\
\hline Constant & $\begin{array}{c}3.69^{* * *} \\
(.31)\end{array}$ & $\begin{array}{c}3.82^{*+*} \\
(.32)\end{array}$ & $\begin{array}{c}8.29^{* * *} \\
(.59)\end{array}$ & $\begin{array}{c}8.22^{* * *} \\
(.61)\end{array}$ & $\begin{array}{c}1.24^{* * *} \\
(.37)\end{array}$ & $\begin{array}{c}1.05^{* *} \\
(.38)\end{array}$ & $\begin{array}{c}1.76^{* * *} \\
(.34)\end{array}$ & $\begin{array}{c}1.74^{* * *} \\
(.35)\end{array}$ & $\begin{array}{c}.32 \\
(.30)\end{array}$ & $\begin{array}{c}.31 \\
(.32)\end{array}$ \\
\hline$N$ & 1,012 & 1,012 & 1,012 & 1,012 & 1,012 & 1,012 & 1,012 & 1,012 & 1,012 & 1,012 \\
\hline Avg. outcome (SD) & $2.55(1.06)$ & $2.55(1.06)$ & $7.27(1.92)$ & $7.27(1.92)$ & $1.05(1.20)$ & $1.05(1.20)$ & $1.31(1.07)$ & $1.31(1.07)$ & $.66(.97)$ & $.66(.97)$ \\
\hline R-squared & .12 & .16 & .06 & .09 & .05 & .09 & .03 & .05 & .05 & .07 \\
\hline
\end{tabular}

Notes: SE's in parentheses. SRH: Self-rated health, Life sat.: Life satisfaction, SD: Standard deviation. ${ }^{*} \mathrm{p}<0.05,{ }^{* *} \mathrm{p}<0.01,{ }^{* * *} \mathrm{p}<0.001$ 
Table A7: Health outcomes regressed on interaction of objective and subjective mobility, OLS regression, controlling for age-squared, $N=1,012$.

\begin{tabular}{|c|c|c|c|c|c|}
\hline & $\begin{array}{l}(1) \\
\text { SRH }\end{array}$ & $\begin{array}{c}(2) \\
\text { Life sat. }\end{array}$ & $\begin{array}{l}(3) \\
\text { Pain }\end{array}$ & $\begin{array}{c}(4) \\
\text { Depression }\end{array}$ & $\begin{array}{c}(5) \\
\text { Loneliness }\end{array}$ \\
\hline \multicolumn{6}{|l|}{ Subjective status mobility (ref. about equal) } \\
\hline (Much) lower status & $\begin{array}{l}.15 \\
(.12)\end{array}$ & $\begin{array}{l}.28 \\
(.22)\end{array}$ & $\begin{array}{l}-.10 \\
(.14)\end{array}$ & $\begin{array}{l}-.01 \\
(.13)\end{array}$ & $\begin{array}{l}.12 \\
(.12)\end{array}$ \\
\hline (Much) higher status & $\begin{array}{l}.03 \\
(.10)\end{array}$ & $\begin{array}{l}.59^{* *} \\
(.19)\end{array}$ & $\begin{array}{l}-.02 \\
(.12)\end{array}$ & $\begin{array}{l}.09 \\
(.11)\end{array}$ & $\begin{array}{l}.05 \\
(.10)\end{array}$ \\
\hline \multicolumn{6}{|l|}{ Objective status mobility (ref. immobile) } \\
\hline Downwardly mobile & $\begin{array}{l}-.01 \\
(.12)\end{array}$ & $\begin{array}{l}.25 \\
(.22)\end{array}$ & $\begin{array}{l}.19 \\
(.14)\end{array}$ & $\begin{array}{l}.04 \\
(.13)\end{array}$ & $\begin{array}{l}-.06 \\
(.11)\end{array}$ \\
\hline Upwardly mobile & $\begin{array}{l}-.16 \\
(.13)\end{array}$ & $\begin{array}{l}.33 \\
(.24)\end{array}$ & $\begin{array}{l}.10 \\
(.15)\end{array}$ & $\begin{array}{l}.46^{* *} \\
(.14)\end{array}$ & $\begin{array}{l}.10 \\
(.13)\end{array}$ \\
\hline \multicolumn{6}{|l|}{ Interaction terms } \\
\hline (Much) lower status $\times$ Downwardly mobile & $\begin{array}{l}-.37^{*} \\
(.18)\end{array}$ & $\begin{array}{l}-.57 \\
(.34)\end{array}$ & $\begin{array}{l}.06 \\
(.21)\end{array}$ & $\begin{array}{l}.15 \\
(.19)\end{array}$ & $\begin{array}{l}.13 \\
(.17)\end{array}$ \\
\hline (Much) lower status $\times$ Upwardly mobile & $\begin{array}{c}-.73^{* *} \\
(.27)\end{array}$ & $\begin{array}{l}-.58 \\
(.50)\end{array}$ & $\begin{array}{c}1.20^{* * *} \\
(.32)\end{array}$ & $\begin{array}{c}.16 \\
(.29)\end{array}$ & $\begin{array}{c}.06 \\
(.26)\end{array}$ \\
\hline (Much) higher status $\times$ Downwardly mobile & $\begin{array}{l}-.21 \\
(.19)\end{array}$ & $\begin{array}{l}-.18 \\
(.37)\end{array}$ & $\begin{array}{l}.02 \\
(.23)\end{array}$ & $\begin{array}{l}-.13 \\
(.21)\end{array}$ & $\begin{array}{l}.09 \\
(.19)\end{array}$ \\
\hline (Much) higher status $\times$ Upwardly mobile & $\begin{array}{l}.23 \\
(.17)\end{array}$ & $\begin{array}{l}-.46 \\
(.31)\end{array}$ & $\begin{array}{l}-.18 \\
(.20)\end{array}$ & $\begin{array}{l}-.57^{* *} \\
(.18)\end{array}$ & $\begin{array}{l}-.15 \\
(.16)\end{array}$ \\
\hline \multicolumn{6}{|l|}{ Control variables } \\
\hline Age & $\begin{array}{l}-.02 \\
(.01)\end{array}$ & $\begin{array}{l}-.03 \\
(.02)\end{array}$ & $\begin{array}{l}-.02 \\
(.01)\end{array}$ & $\begin{array}{l}-.02 \\
(.01)\end{array}$ & $\begin{array}{l}.00 \\
(.01)\end{array}$ \\
\hline Age $\times$ Age & $\begin{array}{l}-.00 \\
(.00)\end{array}$ & $\begin{array}{l}.00 \\
(.00)\end{array}$ & $\begin{array}{l}.00^{*} \\
(.00)\end{array}$ & $\begin{array}{l}.00 \\
(.00)\end{array}$ & $\begin{array}{l}.00 \\
(.00)\end{array}$ \\
\hline Female sex (ref. male) & $\begin{array}{l}-.05 \\
(.06)\end{array}$ & $\begin{array}{c}.12 \\
(.12)\end{array}$ & $\begin{array}{c}.12 \\
(.08)\end{array}$ & $\begin{array}{l}.19^{* *} \\
(.07)\end{array}$ & $\begin{array}{c}.03 \\
(.06)\end{array}$ \\
\hline \multicolumn{6}{|l|}{ Marital status (ref. married) } \\
\hline Widowed/divorced & $\begin{array}{l}-.08 \\
(.09)\end{array}$ & $\begin{array}{l}-.72^{* * *} \\
(.17)\end{array}$ & $\begin{array}{l}.20 \\
(.11)\end{array}$ & $\begin{array}{l}.06 \\
(.10)\end{array}$ & $\begin{array}{l}.56^{* * *} \\
(.09)\end{array}$ \\
\hline Never married & $\begin{array}{l}-.12 \\
(.09)\end{array}$ & $\begin{array}{c}-.47^{* *} \\
(.17)\end{array}$ & $\begin{array}{l}-.04 \\
(.11)\end{array}$ & $\begin{array}{c}.11 \\
(.10)\end{array}$ & $\begin{array}{l}.17 \\
(.09)\end{array}$ \\
\hline East Germany (ref. West) & $\begin{array}{l}-.12 \\
(.07)\end{array}$ & $\begin{array}{c}-.59^{* * *} \\
(.13)\end{array}$ & $\begin{array}{l}.04 \\
(.08)\end{array}$ & $\begin{array}{l}.05 \\
(.07)\end{array}$ & $\begin{array}{l}-.00 \\
(.06)\end{array}$ \\
\hline Constant & $\begin{array}{c}3.77^{* * *} \\
(.32)\end{array}$ & $\begin{array}{c}8.18^{* * *} \\
(.60)\end{array}$ & $\begin{array}{c}1.16^{* *} \\
(.38)\end{array}$ & $\begin{array}{c}1.67^{* * *} \\
(.34)\end{array}$ & $\begin{array}{c}.32 \\
(.31)\end{array}$ \\
\hline$N$ & 1,012 & 1,012 & 1,012 & 1,012 & 1,012 \\
\hline Avg. outcome (SD) & $2.55(1.06)$ & $7.27(1.92)$ & $1.05(1.20)$ & $1.31(1.07)$ & $.66(.97)$ \\
\hline R-squared & .14 & .06 & .07 & .05 & .06 \\
\hline
\end{tabular}

Notes: SE's in parentheses. SRH: Self-rated health, Life sat.: Life satisfaction, SD: Standard deviation. ${ }^{*} \mathrm{p}<0.05,{ }^{* *} \mathrm{p}<0.01,{ }^{* * *} \mathrm{p}<0.001$ 


\section{Controlling for education}

Table A8: Health outcomes regressed on objective mobility trajectories, OLS regression, controlling for education, $N=1,010$.

\begin{tabular}{|c|c|c|c|c|c|}
\hline & $\begin{array}{l}(1) \\
\text { SRH }\end{array}$ & $\begin{array}{c}(2) \\
\text { Life sat. }\end{array}$ & $\begin{array}{l}(3) \\
\text { Pain }\end{array}$ & $\begin{array}{c}(4) \\
\text { Depression }\end{array}$ & $\begin{array}{c}(5) \\
\text { Loneliness }\end{array}$ \\
\hline \multicolumn{6}{|c|}{ Objective mobility trajectory (ref. stably medium) } \\
\hline Stably low & $\begin{array}{l}-.14 \\
(.12)\end{array}$ & $\begin{array}{l}-.25 \\
(.22)\end{array}$ & $\begin{array}{l}.40^{* *} \\
(.14)\end{array}$ & $\begin{array}{l}.12 \\
(.13)\end{array}$ & $\begin{array}{l}.14 \\
(.12)\end{array}$ \\
\hline Low to medium & $\begin{array}{l}-.22 \\
(.13)\end{array}$ & $\begin{array}{l}.03 \\
(.25)\end{array}$ & $\begin{array}{l}.35^{*} \\
(.16)\end{array}$ & $\begin{array}{l}.20 \\
(.15)\end{array}$ & $\begin{array}{l}.11 \\
(.13)\end{array}$ \\
\hline Low to high & $\begin{array}{l}-.19 \\
(.14)\end{array}$ & $\begin{array}{l}-.12 \\
(.27)\end{array}$ & $\begin{array}{c}.22 \\
(.17)\end{array}$ & $\begin{array}{l}.13 \\
(.16)\end{array}$ & $\begin{array}{l}-.03 \\
(.14)\end{array}$ \\
\hline Medium to low & $\begin{array}{l}-.26^{*} \\
(.11)\end{array}$ & $\begin{array}{c}.11 \\
(.22)\end{array}$ & $\begin{array}{l}.33^{*} \\
(.14)\end{array}$ & $\begin{array}{l}.04 \\
(.13)\end{array}$ & $\begin{array}{l}-.07 \\
(.11)\end{array}$ \\
\hline Medium to high & $\begin{array}{l}.08 \\
(.12)\end{array}$ & $\begin{array}{l}.35 \\
(.22)\end{array}$ & $\begin{array}{l}-.05 \\
(.14)\end{array}$ & $\begin{array}{l}-.01 \\
(.13)\end{array}$ & $\begin{array}{l}-.11 \\
(.11)\end{array}$ \\
\hline High to low & $\begin{array}{l}.00 \\
(.16)\end{array}$ & $\begin{array}{l}-.10 \\
(.31)\end{array}$ & $\begin{array}{l}-.02 \\
(.19)\end{array}$ & $\begin{array}{l}-.08 \\
(.18)\end{array}$ & $\begin{array}{l}.21 \\
(.16)\end{array}$ \\
\hline High to medium & $\begin{array}{l}.09 \\
(.13)\end{array}$ & $\begin{array}{l}.24 \\
(.24)\end{array}$ & $\begin{array}{l}.07 \\
(.15)\end{array}$ & $\begin{array}{l}-.17 \\
(.14)\end{array}$ & $\begin{array}{l}-.06 \\
(.12)\end{array}$ \\
\hline Stably high & $\begin{array}{l}.14 \\
(.11)\end{array}$ & $\begin{array}{l}.24 \\
(.20)\end{array}$ & $\begin{array}{l}-.14 \\
(.13)\end{array}$ & $\begin{array}{l}-.19 \\
(.12)\end{array}$ & $\begin{array}{l}-.17 \\
(.11)\end{array}$ \\
\hline \multicolumn{6}{|l|}{ Education (ref. lower) } \\
\hline Medium & $\begin{array}{l}.15 \\
(.10)\end{array}$ & $\begin{array}{l}.52^{* *} \\
(.19)\end{array}$ & $\begin{array}{l}-.30^{*} \\
(.12)\end{array}$ & $\begin{array}{l}-.06 \\
(.11)\end{array}$ & $\begin{array}{l}-.17 \\
(.10)\end{array}$ \\
\hline High & $\begin{array}{l}.37^{* *} \\
(.12)\end{array}$ & $\begin{array}{l}.98^{* * *} \\
(.22)\end{array}$ & $\begin{array}{c}-.56^{* * *} \\
(.14)\end{array}$ & $\begin{array}{l}-.31^{*} \\
(.13)\end{array}$ & $\begin{array}{l}-.14 \\
(.12)\end{array}$ \\
\hline \multicolumn{6}{|l|}{ Control variables } \\
\hline Age & $\begin{array}{c}-.02^{* * *} \\
(.00)\end{array}$ & $\begin{array}{l}.00 \\
(.00)\end{array}$ & $\begin{array}{l}.01^{* * *} \\
(.00)\end{array}$ & $\begin{array}{l}-.01^{*} \\
(.00)\end{array}$ & $\begin{array}{l}.00 \\
(.00)\end{array}$ \\
\hline Female sex (ref. male) & $\begin{array}{l}-.07 \\
(.06)\end{array}$ & $\begin{array}{l}.09 \\
(.12)\end{array}$ & $\begin{array}{l}.15^{*} \\
(.07)\end{array}$ & $\begin{array}{l}.21^{* *} \\
(.07)\end{array}$ & $\begin{array}{l}.06 \\
(.06)\end{array}$ \\
\hline \multicolumn{6}{|l|}{ Marital status (ref. married) } \\
\hline Widowed/divorced & $\begin{array}{l}-.06 \\
(.09)\end{array}$ & $\begin{array}{c}-.67^{* * *} \\
(.16)\end{array}$ & $\begin{array}{l}.19 \\
(.10)\end{array}$ & $\begin{array}{l}.05 \\
(.10)\end{array}$ & $\begin{array}{l}.56^{* * *} \\
(.09)\end{array}$ \\
\hline Never married & $\begin{array}{l}-.13 \\
(.08)\end{array}$ & $\begin{array}{l}-.35^{*} \\
(.16)\end{array}$ & $\begin{array}{l}.05 \\
(.10)\end{array}$ & $\begin{array}{l}.17 \\
(.09)\end{array}$ & $\begin{array}{l}.18^{*} \\
(.08)\end{array}$ \\
\hline East Germany (ref. West) & $\begin{array}{l}-.12 \\
(.07)\end{array}$ & $\begin{array}{c}-.65^{* * *} \\
(.13)\end{array}$ & $\begin{array}{c}.04 \\
(.08)\end{array}$ & $\begin{array}{l}.04 \\
(.07)\end{array}$ & $\begin{array}{l}-.02 \\
(.07)\end{array}$ \\
\hline Constant & $\begin{array}{c}3.56^{* * *} \\
(.18)\end{array}$ & $\begin{array}{c}6.90^{* * *} \\
(.33)\end{array}$ & $\begin{array}{l}.66^{* *} \\
(.21)\end{array}$ & $\begin{array}{c}1.60^{* * *} \\
(.19)\end{array}$ & $\begin{array}{l}.54^{* *} \\
(.17)\end{array}$ \\
\hline$N$ & 1,010 & 1,010 & 1,010 & 1,010 & 1,010 \\
\hline Avg. outcome (SD) & $2.55(1.06)$ & $7.27(1.92)$ & $1.05(1.20)$ & $1.31(1.07)$ & $.66(.97)$ \\
\hline R-squared & .17 & .09 & .10 & .06 & .07 \\
\hline
\end{tabular}

Notes: SE's in parentheses. SRH: Self-rated health, Life sat.: Life satisfaction, SD: Standard deviation. ${ }^{*} \mathrm{p}<0.05,{ }^{* *} \mathrm{p}<0.01,{ }^{* * *} \mathrm{p}<0.001$ 
Table A9: Health outcomes regressed on subjective mobility and objective mobility trajectories, OLS regression, controlling for education, $N=1,010$.

\begin{tabular}{|c|c|c|c|c|c|c|c|c|c|c|}
\hline & $\begin{array}{l}(1) \\
\text { SRH }\end{array}$ & $\begin{array}{l}(2) \\
\text { SRH }\end{array}$ & $\begin{array}{c}(3) \\
\text { Life sat. }\end{array}$ & $\begin{array}{c}(4) \\
\text { Life sat. }\end{array}$ & $\begin{array}{l}(5) \\
\text { Pain }\end{array}$ & $\begin{array}{l}(6) \\
\text { Pain }\end{array}$ & $\begin{array}{c}(7) \\
\text { Depression }\end{array}$ & $\begin{array}{c}(8) \\
\text { Depression }\end{array}$ & $\begin{array}{c}9) \\
\text { Loneliness }\end{array}$ & $\begin{array}{c}(10) \\
\text { Loneliness }\end{array}$ \\
\hline \multicolumn{11}{|c|}{ Subjective status mobility (ref. about equal) } \\
\hline \multirow[t]{2}{*}{ (Much) lower status } & -.07 & -.09 & -.02 & -.07 & .06 & .09 & .02 & .07 & .16 & $.17^{*}$ \\
\hline & $(.08)$ & $(.08)$ & $(.15)$ & (.16) & (.10) & $(.10)$ & $(.09)$ & $(.09)$ & (.08) & $(.08)$ \\
\hline \multirow[t]{2}{*}{ (Much) higher status } & .02 & .04 & $.32^{*}$ & $.36^{* *}$ & -.05 & -.07 & -.04 & -.09 & .04 & .03 \\
\hline & $(.07)$ & $(.07)$ & (.13) & (.13) & $(.08)$ & $(.08)$ & $(.08)$ & $(.08)$ & $(.07)$ & $(.07)$ \\
\hline \multicolumn{11}{|c|}{ Objective mobility trajectory (ref. stably medium) } \\
\hline \multirow[t]{2}{*}{ Stably low } & & -.14 & & -.23 & & $.39^{* *}$ & & .11 & & .14 \\
\hline & & $(.12)$ & & $(.22)$ & & (.14) & & (.13) & & $(.12)$ \\
\hline \multirow[t]{2}{*}{ Low to medium } & & -.22 & & .01 & & $.35^{*}$ & & .21 & & .11 \\
\hline & & (.13) & & $(.25)$ & & (.16) & & (.15) & & (.13) \\
\hline \multirow[t]{2}{*}{ Low to high } & & -.21 & & -.20 & & .24 & & .15 & & -.03 \\
\hline & & $(.15)$ & & $(.27)$ & & (.17) & & (.16) & & (.14) \\
\hline \multirow{2}{*}{ Medium to low } & & $-.23^{*}$ & & .19 & & $.30^{*}$ & & .01 & & -.09 \\
\hline & & $(.12)$ & & $(.22)$ & & (.14) & & (.13) & & (.11) \\
\hline \multirow[t]{2}{*}{ Medium to high } & & .06 & & .27 & & -.03 & & .01 & & -.10 \\
\hline & & $(.12)$ & & $(.22)$ & & (.14) & & (.13) & & $(.12)$ \\
\hline \multirow[t]{2}{*}{ High to low } & & .05 & & .04 & & -.07 & & -.13 & & .16 \\
\hline & & $(.16)$ & & $(.31)$ & & (.19) & & (.18) & & (.16) \\
\hline \multirow[t]{2}{*}{ High to medium } & & .14 & & .37 & & .02 & & -.22 & & -.11 \\
\hline & & (.13) & & (.24) & & $(.15)$ & & (.14) & & (.13) \\
\hline \multirow{2}{*}{ Stably high } & & .16 & & .31 & & -.17 & & -.22 & & -.19 \\
\hline & & (.11) & & $(.20)$ & & (.13) & & $(.12)$ & & (.11) \\
\hline \multicolumn{11}{|l|}{ Education (ref. lower) } \\
\hline \multirow[t]{2}{*}{ Medium } & $.21^{\circ}$ & .15 & $.59^{* *}$ & $.51^{* *}$ & $-.39^{* *}$ & $-.30^{*}$ & -.11 & -.06 & $-.21^{*}$ & -.16 \\
\hline & (.10) & (.10) & (.19) & (.19) & $(.12)$ & $(.12)$ & (.11) & (.11) & (.10) & (.10) \\
\hline \multirow{2}{*}{ High } & $.53^{\cdots \cdots}$ & $.36^{* *}$ & $1.12^{* * *}$ & $.92^{* * *}$ & $-.78^{* * *}$ & $-.54^{* * *}$ & $-43^{*+*}$ & $-.29^{*}$ & $-.26^{*}$ & -.13 \\
\hline & (.11) & (.12) & $(.20)$ & $(.22)$ & $(.13)$ & (.14) & $(.12)$ & (.13) & (.11) & $(.12)$ \\
\hline \multicolumn{11}{|l|}{ Control variables } \\
\hline \multirow[t]{2}{*}{ Age } & $-.02^{* * *}$ & $-.02^{* * *}$ & -.00 & -.00 & . $01^{* * *}$ & $.01^{* * *}$ & $-.01^{*}$ & $-.01^{*}$ & .00 & .00 \\
\hline & $(.00)$ & $(.00)$ & $(.00)$ & $(.00)$ & $(.00)$ & $(.00)$ & $(.00)$ & $(.00)$ & $(.00)$ & $(.00)$ \\
\hline \multirow[t]{2}{*}{ Female sex (ref. male) } & -.05 & -.05 & .15 & .15 & .11 & .13 & $.20^{* *}$ & $.19^{* *}$ & .03 & .04 \\
\hline & $(.06)$ & $(.06)$ & $(.12)$ & $(.12)$ & $(.07)$ & $(.08)$ & $(.07)$ & $(.07)$ & $(.06)$ & $(.06)$ \\
\hline \multicolumn{11}{|l|}{ Marital status (ref. married) } \\
\hline \multirow{2}{*}{ Widowed/divorced } & -.04 & -.05 & $-.65^{* * *}$ & $-.66^{* * *}$ & .18 & .18 & .03 & .04 & $.54^{* * *}$ & $.55^{* * *}$ \\
\hline & $(.09)$ & (.09) & (.16) & (.16) & (.10) & (.10) & (.10) & (.10) & $(.09)$ & (.09) \\
\hline \multirow[t]{2}{*}{ Never married } & -.11 & -.13 & $-.32^{*}$ & $-.35^{*}$ & .02 & .04 & .15 & .17 & .16 & $.17^{*}$ \\
\hline & $(.08)$ & $(.08)$ & (.16) & (.16) & (.10) & (.10) & (.09) & (.09) & (.08) & $(.08)$ \\
\hline East Germany (ref. West) & $-.15^{*}$ & -.12 & $-.65^{* * *}$ & $-.62^{+* *}$ & .08 & .04 & .07 & .04 & .01 & -.01 \\
\hline & $(.07)$ & $(.07)$ & $(.12)$ & (.13) & (.08) & $(.08)$ & $(.07)$ & $(.07)$ & $(.07)$ & $(.07)$ \\
\hline Constant & $3.47^{* * *}$ & $3.56^{* * *}$ & $6.84^{* * *}$ & $6.75^{*+*}$ & $.86^{* * *}$ & $.68^{* *}$ & $1.62^{* * *}$ & $1.62^{* * *}$ & $.49^{* *}$ & $.50^{* *}$ \\
\hline & (.16) & (.18) & $(.30)$ & $(.34)$ & (.19) & (.21) & (.18) & $(.20)$ & (.16) & (.18) \\
\hline$N$ & 1,010 & 1,010 & 1,010 & 1,010 & 1,010 & 1,010 & 1,010 & 1,010 & 1,010 & 1,010 \\
\hline Avg. outcome (SD) & $2.55(1.06)$ & $2.55(1.06)$ & $7.27(1.92)$ & $7.27(1.92)$ & $1.05(1.20)$ & $1.05(1.20)$ & $1.31(1.07)$ & $1.31(1.07)$ & $.66(.97)$ & $.66(.97)$ \\
\hline R-squared & .15 & .17 & .09 & .10 & .08 & .11 & .05 & .06 & .06 & .07 \\
\hline
\end{tabular}

Notes: SE's in parentheses. SRH: Self-rated health, Life sat.: Life satisfaction, SD: Standard deviation. ${ }^{*} \mathrm{p}<0.05,{ }^{* *} \mathrm{p}<0.01,{ }^{* * *} \mathrm{p}<0.001$ 
Table A10: Health outcomes regressed on interaction of objective and subjective mobility, OLS regression, controlling for education, $N=1,010$.

\begin{tabular}{|c|c|c|c|c|c|}
\hline & $\begin{array}{c}(1) \\
\text { SRH }\end{array}$ & $\begin{array}{c}(2) \\
\text { Life sat. }\end{array}$ & $\begin{array}{c}(3) \\
\text { Pain }\end{array}$ & $\begin{array}{c}(4) \\
\text { Depression }\end{array}$ & $\begin{array}{c}(5) \\
\text { Loneliness }\end{array}$ \\
\hline \multicolumn{6}{|l|}{ Subjective status mobility (ref. about equal) } \\
\hline (Much) lower status & $\begin{array}{l}.13 \\
(.12)\end{array}$ & $\begin{array}{l}.24 \\
(.22)\end{array}$ & $\begin{array}{l}-.08 \\
(.14)\end{array}$ & $\begin{array}{l}-.01 \\
(.13)\end{array}$ & $\begin{array}{l}.12 \\
(.12)\end{array}$ \\
\hline (Much) higher status & $\begin{array}{c}.00 \\
(.10)\end{array}$ & $\begin{array}{l}.53^{* *} \\
(.18)\end{array}$ & $\begin{array}{c}.01 \\
(.12)\end{array}$ & $\begin{array}{l}.10 \\
(.11)\end{array}$ & $\begin{array}{c}.06 \\
(.10)\end{array}$ \\
\hline \multicolumn{6}{|l|}{ Objective status mobility (ref. immobile) } \\
\hline Downwardly mobile & $\begin{array}{l}.05 \\
(.12)\end{array}$ & $\begin{array}{l}.38 \\
(.22)\end{array}$ & $\begin{array}{l}.13 \\
(.14)\end{array}$ & $\begin{array}{l}-.03 \\
(.13)\end{array}$ & $\begin{array}{l}-.08 \\
(.12)\end{array}$ \\
\hline Upwardly mobile & $\begin{array}{l}-.14 \\
(.13)\end{array}$ & $\begin{array}{l}.39 \\
(.24)\end{array}$ & $\begin{array}{l}.08 \\
(.15)\end{array}$ & $\begin{array}{l}.42^{* *} \\
(.14)\end{array}$ & $\begin{array}{l}.09 \\
(.13)\end{array}$ \\
\hline \multicolumn{6}{|l|}{ Interaction terms } \\
\hline (Much) lower status $\times$ Downwardly mobile & $\begin{array}{l}-.35^{*} \\
(.18)\end{array}$ & $\begin{array}{l}-.51 \\
(.33)\end{array}$ & $\begin{array}{l}.04 \\
(.21)\end{array}$ & $\begin{array}{l}.15 \\
(.19)\end{array}$ & $\begin{array}{l}.12 \\
(.17)\end{array}$ \\
\hline (Much) lower status $\times$ Upwardly mobile & $\begin{array}{c}-.73^{* *} \\
(.26)\end{array}$ & $\begin{array}{l}-.60 \\
(.49)\end{array}$ & $\begin{array}{c}1.19^{* * *} \\
(.31)\end{array}$ & $\begin{array}{l}.17 \\
(.29)\end{array}$ & $\begin{array}{l}.07 \\
(.26)\end{array}$ \\
\hline (Much) higher status $\times$ Downwardly mobile & $\begin{array}{l}-.16 \\
(.19)\end{array}$ & $\begin{array}{l}-.11 \\
(.36)\end{array}$ & $\begin{array}{l}-.04 \\
(.23)\end{array}$ & $\begin{array}{l}-.15 \\
(.21)\end{array}$ & $\begin{array}{l}.09 \\
(.19)\end{array}$ \\
\hline (Much) higher status $\times$ Upwardly mobile & $\begin{array}{c}.19 \\
(.16)\end{array}$ & $\begin{array}{l}-.55 \\
(.31)\end{array}$ & $\begin{array}{l}-.15 \\
(.19)\end{array}$ & $\begin{array}{c}-.53^{* *} \\
(.18)\end{array}$ & $\begin{array}{l}-.14 \\
(.16)\end{array}$ \\
\hline \multicolumn{6}{|l|}{ Education (ref. lower) } \\
\hline Medium & $\begin{array}{l}.21^{*} \\
(.10)\end{array}$ & $\begin{array}{l}.60^{* *} \\
(.19)\end{array}$ & $\begin{array}{c}-.39^{* * *} \\
(.12)\end{array}$ & $\begin{array}{l}-.11 \\
(.11)\end{array}$ & $\begin{array}{c}-.21^{*} \\
(.10)\end{array}$ \\
\hline High & $\begin{array}{l}.51^{* * *} \\
(.11)\end{array}$ & $\begin{array}{c}1.16^{* * *} \\
(.20)\end{array}$ & $\begin{array}{c}-.76^{* * *} \\
(.13)\end{array}$ & $\begin{array}{c}-.43^{* * *} \\
(.12)\end{array}$ & $\begin{array}{l}-.26^{*} \\
(.11)\end{array}$ \\
\hline \multicolumn{6}{|l|}{ Control variables } \\
\hline Age & $\begin{array}{c}-.02^{* * *} \\
(.00)\end{array}$ & $\begin{array}{l}-.00 \\
(.00)\end{array}$ & $\begin{array}{l}.01^{* * *} \\
(.00)\end{array}$ & $\begin{array}{c}-.01^{*} \\
(.00)\end{array}$ & $\begin{array}{c}.00 \\
(.00)\end{array}$ \\
\hline Female sex (ref. male) & $\begin{array}{l}-.04 \\
(.06)\end{array}$ & $\begin{array}{c}.15 \\
(.12)\end{array}$ & $\begin{array}{l}.10 \\
(.07)\end{array}$ & $\begin{array}{l}.17^{*} \\
(.07)\end{array}$ & $\begin{array}{l}.02 \\
(.06)\end{array}$ \\
\hline \multicolumn{6}{|l|}{ Marital status (ref. married) } \\
\hline Widowed/divorced & $\begin{array}{l}-.06 \\
(.09)\end{array}$ & $\begin{array}{c}-.65^{* * *} \\
(.16)\end{array}$ & $\begin{array}{l}.20 \\
(.10)\end{array}$ & $\begin{array}{l}.05 \\
(.10)\end{array}$ & $\begin{array}{l}.55^{* * *} \\
(.09)\end{array}$ \\
\hline Never married & $\begin{array}{l}-.11 \\
(.08)\end{array}$ & $\begin{array}{l}-.34^{*} \\
(.16)\end{array}$ & $\begin{array}{l}.02 \\
(.10)\end{array}$ & $\begin{array}{l}.15 \\
(.09)\end{array}$ & $\begin{array}{l}.15 \\
(.08)\end{array}$ \\
\hline East Germany (ref. West) & $\begin{array}{l}-.15^{*} \\
(.07)\end{array}$ & $\begin{array}{c}-.65^{* * *} \\
(.12)\end{array}$ & $\begin{array}{l}.08 \\
(.08)\end{array}$ & $\begin{array}{c}.07 \\
(.07)\end{array}$ & $\begin{array}{c}.01 \\
(.07)\end{array}$ \\
\hline Constant & $\begin{array}{c}3.47^{* * *} \\
(.17)\end{array}$ & $\begin{array}{c}6.64^{* * *} \\
(.32)\end{array}$ & $\begin{array}{l}.83^{* * *} \\
(.20)\end{array}$ & $\begin{array}{c}1.59^{* * *} \\
(.19)\end{array}$ & $\begin{array}{l}.51^{* *} \\
(.17)\end{array}$ \\
\hline$N$ & 1,010 & 1,010 & 1,010 & 1,010 & 1,010 \\
\hline Avg. outcome (SD) & $2.55(1.06)$ & $7.27(1.92)$ & $1.05(1.20)$ & $1.31(1.07)$ & $.66(.97)$ \\
\hline R-squared & .17 & .10 & .10 & .07 & .06 \\
\hline
\end{tabular}

Notes: SE's in parentheses. SRH: Self-rated health, Life sat.: Life satisfaction, SD: Standard deviation. ${ }^{*} \mathrm{p}<0.05,{ }^{* *} \mathrm{p}<0.01,{ }^{* * *} \mathrm{p}<0.001$ 


\section{Controlling for labor market status}

Table A11: Health outcomes regressed on objective mobility trajectories, OLS regression, controlling for labor market status, $N=1,012$.

\begin{tabular}{|c|c|c|c|c|c|}
\hline & $\begin{array}{c}(1) \\
\text { SRH }\end{array}$ & $\begin{array}{c}(2) \\
\text { Life sat. }\end{array}$ & $\begin{array}{c}(3) \\
\text { Pain }\end{array}$ & $\begin{array}{c}(4) \\
\text { Depression }\end{array}$ & $\begin{array}{c}(5) \\
\text { Loneliness }\end{array}$ \\
\hline \multicolumn{6}{|c|}{ Objective mobility trajectory (ref. stably medium) } \\
\hline Stably low & $\begin{array}{l}-.18 \\
(.12)\end{array}$ & $\begin{array}{l}-.36 \\
(.22)\end{array}$ & $\begin{array}{l}.45^{* *} \\
(.14)\end{array}$ & $\begin{array}{l}.17 \\
(.13)\end{array}$ & $\begin{array}{l}.15 \\
(.11)\end{array}$ \\
\hline Low to medium & $\begin{array}{l}-.23 \\
(.13)\end{array}$ & $\begin{array}{l}-.03 \\
(.25)\end{array}$ & $\begin{array}{l}.35^{*} \\
(.16)\end{array}$ & $\begin{array}{c}.24 \\
(.15)\end{array}$ & $\begin{array}{l}.11 \\
(.13)\end{array}$ \\
\hline Low to high & $\begin{array}{l}-.11 \\
(.14)\end{array}$ & $\begin{array}{l}-.00 \\
(.27)\end{array}$ & $\begin{array}{l}.12 \\
(.17)\end{array}$ & $\begin{array}{l}.09 \\
(.16)\end{array}$ & $\begin{array}{l}-.03 \\
(.14)\end{array}$ \\
\hline Medium to low & $\begin{array}{l}-.26^{*} \\
(.11)\end{array}$ & $\begin{array}{l}.06 \\
(.21)\end{array}$ & $\begin{array}{l}.35^{*} \\
(.14)\end{array}$ & $\begin{array}{l}.08 \\
(.13)\end{array}$ & $\begin{array}{l}-.09 \\
(.11)\end{array}$ \\
\hline Medium to high & $\begin{array}{l}.13 \\
(.11)\end{array}$ & $\begin{array}{l}.42^{*} \\
(.21)\end{array}$ & $\begin{array}{l}-.13 \\
(.14)\end{array}$ & $\begin{array}{l}-.05 \\
(.13)\end{array}$ & $\begin{array}{l}-.08 \\
(.11)\end{array}$ \\
\hline High to low & $\begin{array}{l}-.00 \\
(.16)\end{array}$ & $\begin{array}{l}-.26 \\
(.30)\end{array}$ & $\begin{array}{l}.01 \\
(.19)\end{array}$ & $\begin{array}{l}-.01 \\
(.18)\end{array}$ & $\begin{array}{l}.24 \\
(.16)\end{array}$ \\
\hline High to medium & $\begin{array}{c}.14 \\
(.13)\end{array}$ & $\begin{array}{l}.29 \\
(.23)\end{array}$ & $\begin{array}{l}.01 \\
(.15)\end{array}$ & $\begin{array}{l}-.17 \\
(.14)\end{array}$ & $\begin{array}{l}-.07 \\
(.12)\end{array}$ \\
\hline Stably high & $\begin{array}{l}.25^{*} \\
(.10)\end{array}$ & $\begin{array}{l}.46^{*} \\
(.19)\end{array}$ & $\begin{array}{l}-.29^{*} \\
(.12)\end{array}$ & $\begin{array}{l}-.30^{* *} \\
(.11)\end{array}$ & $\begin{array}{l}-.15 \\
(.10)\end{array}$ \\
\hline \multicolumn{6}{|c|}{ Labor market stauts (ref. working) } \\
\hline Retired & $\begin{array}{c}-.34^{* *} \\
(.11)\end{array}$ & $\begin{array}{l}.01 \\
(.20)\end{array}$ & $\begin{array}{l}.21 \\
(.13)\end{array}$ & $\begin{array}{l}-.10 \\
(.12)\end{array}$ & $\begin{array}{l}.08 \\
(.11)\end{array}$ \\
\hline Unemployed & $\begin{array}{c}-.49^{* * *} \\
(.14)\end{array}$ & $\begin{array}{c}-1.54^{* * *} \\
(.26)\end{array}$ & $\begin{array}{l}.46^{* *} \\
(.17)\end{array}$ & $\begin{array}{l}.42^{* *} \\
(.15)\end{array}$ & $\begin{array}{l}.58^{* * *} \\
(.14)\end{array}$ \\
\hline Other & $\begin{array}{c}-.32^{* *} \\
(.12)\end{array}$ & $\begin{array}{l}-.50^{*} \\
(.22)\end{array}$ & $\begin{array}{l}.33^{*} \\
(.14)\end{array}$ & $\begin{array}{l}.03 \\
(.13)\end{array}$ & $\begin{array}{l}.22 \\
(.12)\end{array}$ \\
\hline \multicolumn{6}{|l|}{ Control variables } \\
\hline Age & $\begin{array}{c}-.02^{* * *} \\
(.00)\end{array}$ & $\begin{array}{l}-.00 \\
(.01)\end{array}$ & $\begin{array}{l}.01 \\
(.00)\end{array}$ & $\begin{array}{l}-.00 \\
(.00)\end{array}$ & $\begin{array}{l}.00 \\
(.00)\end{array}$ \\
\hline Female sex (ref. male) & $\begin{array}{l}-.04 \\
(.06)\end{array}$ & $\begin{array}{l}.10 \\
(.12)\end{array}$ & $\begin{array}{l}.13 \\
(.08)\end{array}$ & $\begin{array}{l}.23^{* * *} \\
(.07)\end{array}$ & $\begin{array}{l}.04 \\
(.06)\end{array}$ \\
\hline \multicolumn{6}{|l|}{ Marital status (ref. married) } \\
\hline Widowed/divorced & $\begin{array}{l}-.05 \\
(.09)\end{array}$ & $\begin{array}{c}-.63^{* * *} \\
(.16)\end{array}$ & $\begin{array}{l}.19 \\
(.10)\end{array}$ & $\begin{array}{l}.04 \\
(.10)\end{array}$ & $\begin{array}{l}.53^{* * *} \\
(.09)\end{array}$ \\
\hline Never married & $\begin{array}{l}-.11 \\
(.09)\end{array}$ & $\begin{array}{c}-.42^{* *} \\
(.16)\end{array}$ & $\begin{array}{c}.07 \\
(.10)\end{array}$ & $\begin{array}{l}.19^{*} \\
(.09)\end{array}$ & $\begin{array}{l}.19^{*} \\
(.08)\end{array}$ \\
\hline East Germany (ref. West) & $\begin{array}{l}-.09 \\
(.07)\end{array}$ & $\begin{array}{c}-.55^{* * *} \\
(.12)\end{array}$ & $\begin{array}{l}-.01 \\
(.08)\end{array}$ & $\begin{array}{l}.01 \\
(.07)\end{array}$ & $\begin{array}{l}-.04 \\
(.06)\end{array}$ \\
\hline Constant & $\begin{array}{c}3.54^{* * *} \\
(.17)\end{array}$ & $\begin{array}{c}7.74^{* * *} \\
(.33)\end{array}$ & $\begin{array}{l}.43^{*} \\
(.21)\end{array}$ & $\begin{array}{c}1.34^{* * *} \\
(.19)\end{array}$ & $\begin{array}{l}.36^{*} \\
(.17)\end{array}$ \\
\hline$N$ & 1,012 & 1,012 & 1,012 & 1,012 & 1,012 \\
\hline Avg. outcome (SD) & $2.55(1.06)$ & $7.27(1.92)$ & $1.05(1.20)$ & $1.31(1.07)$ & $.66(.97)$ \\
\hline R-squared & .17 & .11 & .10 & .06 & .08 \\
\hline
\end{tabular}

Notes: SE's in parentheses. SRH: Self-rated health, Life sat.: Life satisfaction, SD: Standard deviation. ${ }^{*} \mathrm{p}<0.05,{ }^{*} * \mathrm{p}<0.01,{ }^{* * *} \mathrm{p}<0.001$ 
Table A12: Health outcomes regressed on subjective mobility and objective mobility trajectories, OLS regression, controlling for labor market status, $N=1,012$.

\begin{tabular}{|c|c|c|c|c|c|c|c|c|c|c|}
\hline & $\begin{array}{c}(1) \\
\text { SRH }\end{array}$ & $\begin{array}{c}(2) \\
\text { SRH }\end{array}$ & $\begin{array}{c}(3) \\
\text { Life sat. }\end{array}$ & $\begin{array}{c}(4) \\
\text { Life sat. }\end{array}$ & $\begin{array}{l}(5) \\
\text { Pain }\end{array}$ & $\begin{array}{l}(6) \\
\text { Pain }\end{array}$ & $\begin{array}{c}(7) \\
\text { Depression } \\
\end{array}$ & $\begin{array}{c}(8) \\
\text { Depression } \\
\end{array}$ & $\begin{array}{c}(9) \\
\text { Loneliness }\end{array}$ & $\begin{array}{c}(10) \\
\text { Loneliness }\end{array}$ \\
\hline \multicolumn{11}{|c|}{ Subjective status mobility (ref. about equal) } \\
\hline (Much) lower status & $\begin{array}{l}-.05 \\
(.08)\end{array}$ & $\begin{array}{l}-.08 \\
(.08)\end{array}$ & $\begin{array}{l}. .01 \\
(.15)\end{array}$ & $\begin{array}{l}-.05 \\
(.16)\end{array}$ & $\begin{array}{c}.04 \\
(.10)\end{array}$ & $\begin{array}{l}.07 \\
(.10)\end{array}$ & $\begin{array}{l}.02 \\
(.09)\end{array}$ & $\begin{array}{l}.07 \\
(.09)\end{array}$ & $\begin{array}{l}.15 \\
(.08)\end{array}$ & $\begin{array}{l}.16 \\
(.08)\end{array}$ \\
\hline (Much) higher status & $\begin{array}{l}.03 \\
(.07)\end{array}$ & $\begin{array}{l}.03 \\
(.07)\end{array}$ & $\begin{array}{l}.35^{* *} \\
(.13)\end{array}$ & $\begin{array}{l}.36^{* *} \\
(.13)\end{array}$ & $\begin{array}{l}-.09 \\
(.08)\end{array}$ & $\begin{array}{l}-.08 \\
(.08)\end{array}$ & $\begin{array}{l}-.07 \\
(.08)\end{array}$ & $\begin{array}{l}-.10 \\
(.08)\end{array}$ & $\begin{array}{l}.05 \\
(.07)\end{array}$ & $\begin{array}{l}.05 \\
(.07)\end{array}$ \\
\hline \multicolumn{11}{|c|}{ Objective mobility trajectory (ref. stably medium) } \\
\hline Stably low & & $\begin{array}{l}-.17 \\
(.12)\end{array}$ & & $\begin{array}{l}-.34 \\
(.22)\end{array}$ & & $\begin{array}{l}.44^{* *} \\
(.14)\end{array}$ & & $\begin{array}{c}.16 \\
(.13)\end{array}$ & & $\begin{array}{l}.14 \\
(.11)\end{array}$ \\
\hline Low to medium & & $\begin{array}{l}-.23 \\
(.13)\end{array}$ & & $\begin{array}{l}-.05 \\
(.25)\end{array}$ & & $\begin{array}{l}.36^{*} \\
(.16)\end{array}$ & & $\begin{array}{c}.24 \\
(.15)\end{array}$ & & $\begin{array}{l}.11 \\
(.13)\end{array}$ \\
\hline Low to high & & $\begin{array}{l}-.13 \\
(.14)\end{array}$ & & $\begin{array}{l}-.10 \\
(.27)\end{array}$ & & $\begin{array}{l}.15 \\
(.17)\end{array}$ & & $\begin{array}{l}.12 \\
(.16)\end{array}$ & & $\begin{array}{l}-.03 \\
(.14)\end{array}$ \\
\hline Medium to low & & $\begin{array}{l}-.24^{*} \\
(.11)\end{array}$ & & $\begin{array}{l}.13 \\
(.21)\end{array}$ & & $\begin{array}{r}.32^{*} \\
(.14)\end{array}$ & & $\begin{array}{l}.05 \\
(.13)\end{array}$ & & $\begin{array}{c}-.10 \\
(.11)\end{array}$ \\
\hline Medium to high & & $\begin{array}{l}.12 \\
(.11)\end{array}$ & & $\begin{array}{l}.34 \\
(.21)\end{array}$ & & $\begin{array}{c}-.11 \\
(.14)\end{array}$ & & $\begin{array}{l}-.02 \\
(.13)\end{array}$ & & $\begin{array}{l}-.07 \\
(.11)\end{array}$ \\
\hline High to low & & $\begin{array}{l}.04 \\
(.16)\end{array}$ & & $\begin{array}{l}-.13 \\
(.31)\end{array}$ & & $\begin{array}{l}-.04 \\
(.20)\end{array}$ & & $\begin{array}{l}-.07 \\
(.18)\end{array}$ & & $\begin{array}{l}.20 \\
(.16)\end{array}$ \\
\hline High to medium & & $\begin{array}{l}.17 \\
(.13)\end{array}$ & & $\begin{array}{l}.40 \\
(.24)\end{array}$ & & $\begin{array}{l}-.03 \\
(.15)\end{array}$ & & $\begin{array}{l}-.22 \\
(.14)\end{array}$ & & $\begin{array}{l}-.11 \\
(.13)\end{array}$ \\
\hline Stably high & & $\begin{array}{l}.26^{* *} \\
(.10)\end{array}$ & & $\begin{array}{l}.51^{* *} \\
(.19)\end{array}$ & & $\begin{array}{l}-.31^{*} \\
(.12)\end{array}$ & & $\begin{array}{c}-.32^{* *} \\
(.11)\end{array}$ & & $\begin{array}{c}-.16 \\
(.10)\end{array}$ \\
\hline \multicolumn{11}{|c|}{ Labor market status (ref. working) } \\
\hline Retired & $\begin{array}{c}-.39^{* * *} \\
(.11)\end{array}$ & $\begin{array}{c}-.34^{* *} \\
(.11)\end{array}$ & $\begin{array}{c}-.02 \\
(.20)\end{array}$ & $\begin{array}{l}.04 \\
(.20)\end{array}$ & $\begin{array}{l}.27^{*} \\
(.13)\end{array}$ & $\begin{array}{l}.20 \\
(.13)\end{array}$ & $\begin{array}{l}-.07 \\
(.12)\end{array}$ & $\begin{array}{c}-.11 \\
(.12)\end{array}$ & $\begin{array}{l}.10 \\
(.10)\end{array}$ & $\begin{array}{l}.08 \\
(.11)\end{array}$ \\
\hline Unemployed & $\begin{array}{c}-.56^{+* * *} \\
(.14)\end{array}$ & $\begin{array}{c}-.47^{* * *} \\
(.14)\end{array}$ & $\begin{array}{c}-1.59^{* * *} \\
(.26)\end{array}$ & $\begin{array}{c}-1.49^{* * *} \\
(.26)\end{array}$ & $\begin{array}{l}.57^{* * * *} \\
(.17)\end{array}$ & $\begin{array}{l}.45^{* *} \\
(.17)\end{array}$ & $\begin{array}{l}.47^{* *} \\
(.15)\end{array}$ & $\begin{array}{l}.40^{* * *} \\
(.15)\end{array}$ & $\begin{array}{l}.59^{+* *+} \\
(.14)\end{array}$ & $\begin{array}{l}.57^{* * * *} \\
(.14)\end{array}$ \\
\hline Other & $\begin{array}{l}-.35^{* *} \\
(.12)\end{array}$ & $\begin{array}{l}-.31^{* *} \\
(.12)\end{array}$ & $\begin{array}{l}-.49^{*} \\
(.22)\end{array}$ & $\begin{array}{l}-.44^{*} \\
(.22)\end{array}$ & $\begin{array}{l}.37^{* *} \\
(.14)\end{array}$ & $\begin{array}{l}.32^{*} \\
(.14)\end{array}$ & $\begin{array}{l}.05 \\
(.13)\end{array}$ & $\begin{array}{l}.01 \\
(.13)\end{array}$ & $\begin{array}{l}.22 \\
(.12)\end{array}$ & $\begin{array}{l}.22 \\
(.12)\end{array}$ \\
\hline \multicolumn{11}{|l|}{ Control variables } \\
\hline Age & $\begin{array}{c}-.02^{* * *} \\
(.00)\end{array}$ & $\begin{array}{c}-.02^{* * *} \\
(.00)\end{array}$ & $\begin{array}{l}-.00 \\
(.01)\end{array}$ & $\begin{array}{l}-.00 \\
(.01)\end{array}$ & $\begin{array}{l}.01 \\
(.00)\end{array}$ & $\begin{array}{l}.01 \\
(.00)\end{array}$ & $\begin{array}{l}-.00 \\
(.00)\end{array}$ & $\begin{array}{l}-.00 \\
(.00)\end{array}$ & $\begin{array}{l}.00 \\
(.00)\end{array}$ & $\begin{array}{l}.00 \\
(.00)\end{array}$ \\
\hline Female sex (ref. male) & $\begin{array}{l}-.02 \\
(.06)\end{array}$ & $\begin{array}{l}-.03 \\
(.06)\end{array}$ & $\begin{array}{l}.17 \\
(.12)\end{array}$ & $\begin{array}{l}.16 \\
(.12)\end{array}$ & $\begin{array}{l}.08 \\
(.08)\end{array}$ & $\begin{array}{l}.11 \\
(.08)\end{array}$ & $\begin{array}{l}.21^{* *} \\
(.07)\end{array}$ & $\begin{array}{l}.21^{* *} \\
(.07)\end{array}$ & $\begin{array}{l}.01 \\
(.06)\end{array}$ & $\begin{array}{l}.02 \\
(.06)\end{array}$ \\
\hline \multicolumn{11}{|l|}{ Marital status (ref. married) } \\
\hline Widowed/divorced & $\begin{array}{l}-.04 \\
(.09)\end{array}$ & $\begin{array}{l}-.04 \\
(.09)\end{array}$ & $\begin{array}{c}-.62^{* * *} \\
(.16)\end{array}$ & $\begin{array}{c}-.62^{* * *} \\
(.16)\end{array}$ & $\begin{array}{l}.19 \\
(.11)\end{array}$ & $\begin{array}{l}.19 \\
(.10)\end{array}$ & $\begin{array}{c}.02 \\
(.10)\end{array}$ & $\begin{array}{c}.03 \\
(.10)\end{array}$ & $\begin{array}{l}.52^{2 * * *} \\
(.09)\end{array}$ & $\begin{array}{l}.53^{* * *} \\
(.09)\end{array}$ \\
\hline Never married & $\begin{array}{l}-.09 \\
(.09)\end{array}$ & $\begin{array}{l}-.11 \\
(.09)\end{array}$ & $\begin{array}{l}-.39^{*} \\
(.16)\end{array}$ & $\begin{array}{c}-.41^{* *} \\
(.16)\end{array}$ & $\begin{array}{l}.04 \\
(.10)\end{array}$ & $\begin{array}{l}.07 \\
(.10)\end{array}$ & $\begin{array}{l}.17 \\
(.09)\end{array}$ & $\begin{array}{l}.19^{*} \\
(.09)\end{array}$ & $\begin{array}{l}.17^{*} \\
(.08)\end{array}$ & $\begin{array}{l}.18^{*} \\
(.08)\end{array}$ \\
\hline East Germany (ref. West) & $\begin{array}{l}-.12 \\
(.07)\end{array}$ & $\begin{array}{l}-.09 \\
(.07)\end{array}$ & $\begin{array}{r}-.57^{* * *} \\
(.12)\end{array}$ & $\begin{array}{c}-.52^{* * *} \\
(.12)\end{array}$ & $\begin{array}{l}.04 \\
(.08)\end{array}$ & $\begin{array}{l}-.01 \\
(.08)\end{array}$ & $\begin{array}{l}.04 \\
(.07)\end{array}$ & $\begin{array}{l}.00 \\
(.07)\end{array}$ & $\begin{array}{l}.01 \\
(.06)\end{array}$ & $\begin{array}{c}.03 \\
(.07)\end{array}$ \\
\hline Constant & $\begin{array}{c}3.54^{* * *} \\
(.16) \\
\end{array}$ & $\begin{array}{c}3.54^{* * * *} \\
(.18) \\
\end{array}$ & $\begin{array}{c}7.78^{* * * *} \\
(.30) \\
\end{array}$ & $\begin{array}{c}7.58^{*+*} \\
(.33) \\
\end{array}$ & $\begin{array}{l}.49^{*} \\
(.19) \\
\end{array}$ & $\begin{array}{l}.46^{*} \\
(.21) \\
\end{array}$ & $\begin{array}{c}1.31^{* * * *} \\
(.18)\end{array}$ & $\begin{array}{c}1.37^{* * *} \\
(.20) \\
\end{array}$ & $\begin{array}{l}.27 \\
(.16) \\
\end{array}$ & $\begin{array}{c}.31 \\
(.18) \\
\end{array}$ \\
\hline$N$ & 1,012 & 1,012 & 1,012 & 1,012 & 1,012 & 1,012 & 1,012 & 1,012 & 1,012 & 1,012 \\
\hline Avg. outcome (SD) & $2.55(1.06)$ & $2.55(1.06)$ & $7.27(1.92)$ & $7.27(1.92)$ & $1.05(1.20)$ & $1.05(1.20)$ & $1.31(1.07)$ & $1.31(1.07)$ & $.66(.97)$ & $.66(.97)$ \\
\hline R-squared & .15 & .18 & .09 & .12 & .06 & .10 & .04 & .06 & .07 & .09 \\
\hline
\end{tabular}

Notes: SE's in parentheses. SRH: Self-rated health, Life sat.: Life satisfaction, SD: Standard deviation. ${ }^{*} \mathrm{p}<0.05,{ }^{* *} \mathrm{p}<0.01,{ }^{* * *} \mathrm{p}<0.001$ 
Table A13: Health outcomes regressed on interaction of objective and subjective mobility, OLS regression, controlling for labor market status, $N=1,012$.

\begin{tabular}{|c|c|c|c|c|c|}
\hline & $\begin{array}{c}(1) \\
\text { SRH }\end{array}$ & $\begin{array}{c}(2) \\
\text { Life sat. }\end{array}$ & $\begin{array}{c}(3) \\
\text { Pain }\end{array}$ & $\begin{array}{c}(4) \\
\text { Depression }\end{array}$ & $\begin{array}{c}(5) \\
\text { Loneliness }\end{array}$ \\
\hline \multicolumn{6}{|l|}{ Subjective status mobility (ref. about equal) } \\
\hline (Much) lower status & $\begin{array}{l}.15 \\
(.12)\end{array}$ & $\begin{array}{l}.26 \\
(.22)\end{array}$ & $\begin{array}{l}-.11 \\
(.14)\end{array}$ & $\begin{array}{l}-.01 \\
(.13)\end{array}$ & $\begin{array}{l}.12 \\
(.12)\end{array}$ \\
\hline (Much) higher status & $\begin{array}{l}.01 \\
(.10)\end{array}$ & $\begin{array}{l}.55^{* *} \\
(.18)\end{array}$ & $\begin{array}{l}-.02 \\
(.12)\end{array}$ & $\begin{array}{l}.08 \\
(.11)\end{array}$ & $\begin{array}{l}.06 \\
(.10)\end{array}$ \\
\hline \multicolumn{6}{|l|}{ Objective status mobility (ref. immobile) } \\
\hline Downwardly mobile & $\begin{array}{l}.00 \\
(.12)\end{array}$ & $\begin{array}{l}.23 \\
(.22)\end{array}$ & $\begin{array}{l}.19 \\
(.14)\end{array}$ & $\begin{array}{l}.05 \\
(.13)\end{array}$ & $\begin{array}{l}-.06 \\
(.11)\end{array}$ \\
\hline Upwardly mobile & $\begin{array}{l}-.13 \\
(.13)\end{array}$ & $\begin{array}{l}.40 \\
(.24)\end{array}$ & $\begin{array}{l}.07 \\
(.15)\end{array}$ & $\begin{array}{l}.45^{* *} \\
(.14)\end{array}$ & $\begin{array}{l}.07 \\
(.13)\end{array}$ \\
\hline \multicolumn{6}{|l|}{ Interaction terms } \\
\hline (Much) lower status $\times$ Downwardly mobile & $\begin{array}{l}-.34 \\
(.18)\end{array}$ & $\begin{array}{l}-.45 \\
(.33)\end{array}$ & $\begin{array}{l}.04 \\
(.21)\end{array}$ & $\begin{array}{l}.14 \\
(.19)\end{array}$ & $\begin{array}{l}.10 \\
(.17)\end{array}$ \\
\hline (Much) lower status $\times$ Upwardly mobile & $\begin{array}{l}-.70^{* *} \\
(.26)\end{array}$ & $\begin{array}{l}-.58 \\
(.49)\end{array}$ & $\begin{array}{c}1.17^{* * *} \\
(.32)\end{array}$ & $\begin{array}{l}.17 \\
(.29)\end{array}$ & $\begin{array}{l}.05 \\
(.26)\end{array}$ \\
\hline (Much) higher status $\times$ Downwardly mobile & $\begin{array}{l}-.17 \\
(.19)\end{array}$ & $\begin{array}{l}-.11 \\
(.36)\end{array}$ & $\begin{array}{l}-.00 \\
(.23)\end{array}$ & $\begin{array}{l}-.13 \\
(.21)\end{array}$ & $\begin{array}{l}.06 \\
(.19)\end{array}$ \\
\hline (Much) higher status $\times$ Upwardly mobile & $\begin{array}{l}.18 \\
(.16)\end{array}$ & $\begin{array}{l}-.60 \\
(.31)\end{array}$ & $\begin{array}{l}-.14 \\
(.20)\end{array}$ & $\begin{array}{l}-.54^{* *} \\
(.18)\end{array}$ & $\begin{array}{l}-.10 \\
(.16)\end{array}$ \\
\hline \multicolumn{6}{|l|}{ Labor market status (ref. working) } \\
\hline Retired & $\begin{array}{c}-.35^{* *} \\
(.11)\end{array}$ & $\begin{array}{l}-.04 \\
(.20)\end{array}$ & $\begin{array}{c}.22 \\
(.13)\end{array}$ & $\begin{array}{l}-.10 \\
(.12)\end{array}$ & $\begin{array}{c}.10 \\
(.11)\end{array}$ \\
\hline Unemployed & $\begin{array}{c}-.53^{* * *} \\
(.14)\end{array}$ & $\begin{array}{c}-1.62^{* * *} \\
(.26)\end{array}$ & $\begin{array}{l}.55^{* *} \\
(.17)\end{array}$ & $\begin{array}{l}.43^{* *} \\
(.15)\end{array}$ & $\begin{array}{l}.58^{* * *} \\
(.14)\end{array}$ \\
\hline Other & $\begin{array}{l}-.30^{*} \\
(.12)\end{array}$ & $\begin{array}{l}-.49^{*} \\
(.22)\end{array}$ & $\begin{array}{l}.32^{*} \\
(.14)\end{array}$ & $\begin{array}{l}.01 \\
(.13)\end{array}$ & $\begin{array}{l}.21 \\
(.12)\end{array}$ \\
\hline \multicolumn{6}{|l|}{ Control variables } \\
\hline Age & $\begin{array}{c}-.02^{* * *} \\
(.00)\end{array}$ & $\begin{array}{l}-.00 \\
(.01)\end{array}$ & $\begin{array}{l}.01^{*} \\
(.00)\end{array}$ & $\begin{array}{l}-.00 \\
(.00)\end{array}$ & $\begin{array}{l}.00 \\
(.00)\end{array}$ \\
\hline Female sex (ref. male) & $\begin{array}{l}-.02 \\
(.06)\end{array}$ & $\begin{array}{l}.16 \\
(.12)\end{array}$ & $\begin{array}{c}.09 \\
(.08)\end{array}$ & $\begin{array}{l}.19^{* *} \\
(.07)\end{array}$ & $\begin{array}{c}.01 \\
(.06)\end{array}$ \\
\hline \multicolumn{6}{|l|}{ Marital status (ref. married) } \\
\hline Widowed/divorced & $\begin{array}{l}-.05 \\
(.09)\end{array}$ & $\begin{array}{c}-.61^{* * *} \\
(.16)\end{array}$ & $\begin{array}{l}.20 \\
(.11)\end{array}$ & $\begin{array}{l}.04 \\
(.10)\end{array}$ & $\begin{array}{l}.53^{* * *} \\
(.09)\end{array}$ \\
\hline Never married & $\begin{array}{l}-.08 \\
(.09)\end{array}$ & $\begin{array}{l}-.41^{*} \\
(.16)\end{array}$ & $\begin{array}{l}.04 \\
(.10)\end{array}$ & $\begin{array}{l}.16 \\
(.09)\end{array}$ & $\begin{array}{l}.17^{*} \\
(.08)\end{array}$ \\
\hline East Germany (ref. West) & $\begin{array}{l}-.12 \\
(.07)\end{array}$ & $\begin{array}{c}-.56^{* * *} \\
(.12)\end{array}$ & $\begin{array}{l}.04 \\
(.08)\end{array}$ & $\begin{array}{l}.04 \\
(.07)\end{array}$ & $\begin{array}{l}-.01 \\
(.07)\end{array}$ \\
\hline Constant & $\begin{array}{c}3.57^{* * *} \\
(.17)\end{array}$ & $\begin{array}{c}7.64^{* * *} \\
(.32)\end{array}$ & $\begin{array}{l}.41^{*} \\
(.20)\end{array}$ & $\begin{array}{c}1.22^{* * *} \\
(.19)\end{array}$ & $\begin{array}{c}.28 \\
(.17)\end{array}$ \\
\hline$N$ & 1,012 & 1,012 & 1,012 & 1,012 & 1,012 \\
\hline Avg. outcome (SD) & $2.55(1.06)$ & $7.27(1.92)$ & $1.05(1.20)$ & $1.31(1.07)$ & $.66(.97)$ \\
\hline R-squared & .16 & .10 & .08 & .05 & .08 \\
\hline
\end{tabular}

Notes: SE's in parentheses. SRH: Self-rated health, Life sat.: Life satisfaction, SD: Standard deviation. ${ }^{*} \mathrm{p}<0.05,{ }^{* *} \mathrm{p}<0.01,{ }^{*}{ }^{*}-17<0.001$ 


\section{OLS regression with weights}

The use of weights in multivariate analyses is a charged topic, with some arguing for it, and others against it (e.g. Angrist and Pischke, 2009; Deaton, 2018; Gelman, 2007). The German General Social Survey oversamples Eastern Germans and provides a simple weight variable to correct for it.

Table A14: Health outcomes regressed on objective mobility trajectories, OLS regression, weighted analysis, $N=1,012$.

\begin{tabular}{|c|c|c|c|c|c|}
\hline & $\begin{array}{c}(1) \\
\text { SRH }\end{array}$ & $\begin{array}{c}(2) \\
\text { Life sat. }\end{array}$ & $\begin{array}{c}\text { (3) } \\
\text { Pain }\end{array}$ & $\begin{array}{c}(4) \\
\text { Depression }\end{array}$ & $\begin{array}{c}(5) \\
\text { Loneliness }\end{array}$ \\
\hline \multicolumn{6}{|c|}{ Objective mobility trajectory (ref. stably medium) } \\
\hline Stably low & $\begin{array}{l}-.26^{*} \\
(.13)\end{array}$ & $\begin{array}{l}-.37 \\
(.27)\end{array}$ & $\begin{array}{l}.46^{* *} \\
(.16)\end{array}$ & $\begin{array}{l}.13 \\
(.15)\end{array}$ & $\begin{array}{l}.22 \\
(.13)\end{array}$ \\
\hline Low to medium & $\begin{array}{l}-.22 \\
(.16)\end{array}$ & $\begin{array}{l}.01 \\
(.26)\end{array}$ & $\begin{array}{l}.35^{*} \\
(.17)\end{array}$ & $\begin{array}{l}.18 \\
(.15)\end{array}$ & $\begin{array}{l}.13 \\
(.15)\end{array}$ \\
\hline Low to high & $\begin{array}{l}-.18 \\
(.15)\end{array}$ & $\begin{array}{l}-.07 \\
(.26)\end{array}$ & $\begin{array}{c}.15 \\
(.17)\end{array}$ & $\begin{array}{l}.10 \\
(.15)\end{array}$ & $\begin{array}{l}.04 \\
(.14)\end{array}$ \\
\hline Medium to low & $\begin{array}{l}-.29^{*} \\
(.13)\end{array}$ & $\begin{array}{l}.03 \\
(.23)\end{array}$ & $\begin{array}{l}.36^{*} \\
(.15)\end{array}$ & $\begin{array}{l}.05 \\
(.13)\end{array}$ & $\begin{array}{l}-.02 \\
(.12)\end{array}$ \\
\hline Medium to high & $\begin{array}{l}.15 \\
(.11)\end{array}$ & $\begin{array}{l}.48^{*} \\
(.23)\end{array}$ & $\begin{array}{l}-.19 \\
(.14)\end{array}$ & $\begin{array}{l}-.12 \\
(.13)\end{array}$ & $\begin{array}{l}-.12 \\
(.12)\end{array}$ \\
\hline High to low & $\begin{array}{l}-.01 \\
(.15)\end{array}$ & $\begin{array}{l}-.26 \\
(.38)\end{array}$ & $\begin{array}{l}-.04 \\
(.21)\end{array}$ & $\begin{array}{l}-.08 \\
(.21)\end{array}$ & $\begin{array}{c}.22 \\
(.21)\end{array}$ \\
\hline High to medium & $\begin{array}{l}.10 \\
.13)\end{array}$ & $\begin{array}{c}.26 \\
(.26)\end{array}$ & $\begin{array}{l}-.03 \\
(.15)\end{array}$ & $\begin{array}{l}-.22 \\
(.14)\end{array}$ & $\begin{array}{l}-.05 \\
(.13)\end{array}$ \\
\hline Stably high & $\begin{array}{l}.28^{* *} \\
(.10)\end{array}$ & $\begin{array}{l}.51^{*} \\
(.20)\end{array}$ & $\begin{array}{c}-.36^{* *} \\
(.12)\end{array}$ & $\begin{array}{r}-.34^{* *} \\
(.11)\end{array}$ & $\begin{array}{l}-.16 \\
(.10)\end{array}$ \\
\hline \multicolumn{6}{|l|}{ Control variables } \\
\hline Age & $\begin{array}{c}-.02^{* * *} \\
(.00)\end{array}$ & $\begin{array}{c}.00 \\
(.00)\end{array}$ & $\begin{array}{l}.01^{* * *} \\
. .00)\end{array}$ & $\begin{array}{l}-.00 \\
(.00)\end{array}$ & $\begin{array}{c}.00 \\
(.00)\end{array}$ \\
\hline Female sex (ref. male) & $\begin{array}{l}-.09 \\
(.06)\end{array}$ & $\begin{array}{l}.01 \\
(.12)\end{array}$ & $\begin{array}{l}.18^{*} \\
(.08)\end{array}$ & $\begin{array}{l}.25^{* * *} \\
(.07)\end{array}$ & $\begin{array}{l}.08 \\
(.06)\end{array}$ \\
\hline \multicolumn{6}{|l|}{ Marital status (ref. married) } \\
\hline Widowed/divorced & $\begin{array}{l}-.07 \\
(.10)\end{array}$ & $\begin{array}{c}-.74^{* * *} \\
(.19)\end{array}$ & $\begin{array}{l}.25^{*} \\
(.12)\end{array}$ & $\begin{array}{l}.04 \\
(.10)\end{array}$ & $\begin{array}{l}.58^{* * *} \\
(.11)\end{array}$ \\
\hline Never married & $\begin{array}{l}-.14 \\
(.08)\end{array}$ & $\begin{array}{l}-.44^{* *} \\
(.17)\end{array}$ & $\begin{array}{l}.08 \\
(.10)\end{array}$ & $\begin{array}{l}.22^{*} \\
(.09)\end{array}$ & $\begin{array}{l}.18^{*} \\
(.08)\end{array}$ \\
\hline East Germany (ref. West) & $\begin{array}{l}-.09 \\
(.07)\end{array}$ & $\begin{array}{c}-.58^{* * *} \\
(.13)\end{array}$ & $\begin{array}{l}-.01 \\
(.08)\end{array}$ & $\begin{array}{c}.02 \\
(.07)\end{array}$ & $\begin{array}{l}-.03 \\
(.07)\end{array}$ \\
\hline Constant & $\begin{array}{c}3.76^{* * *} \\
(.14)\end{array}$ & $\begin{array}{c}7.51^{* * *} \\
(.31)\end{array}$ & $\begin{array}{l}.36^{*} \\
(.18)\end{array}$ & $\begin{array}{c}1.41^{* * *} \\
(.17)\end{array}$ & $\begin{array}{l}.34^{*} \\
(.15)\end{array}$ \\
\hline$N$ & 1,012 & 1,012 & 1,012 & 1,012 & 1,012 \\
\hline Avg. outcome (SD) & $2.55(1.06)$ & $7.27(1.92)$ & $1.05(1.20)$ & $1.31(1.07)$ & $.66(.97)$ \\
\hline R-squared & .16 & .07 & .10 & .05 & .07 \\
\hline
\end{tabular}

Notes: SE's in parentheses. SRH: Self-rated health, Life sat.: Life satisfaction, SD: Standard deviation. ${ }^{*} \mathrm{p}<0.05,{ }^{* *} \mathrm{p}<0.01,{ }^{* * *} \mathrm{p}<0.001$ 
Table A15: Health outcomes regressed on subjective mobility and objective mobility trajectories, OLS regression, weighted analysis, $N=1,012$.

\begin{tabular}{|c|c|c|c|c|c|c|c|c|c|c|}
\hline & $\begin{array}{c}(1) \\
\text { SRH } \\
\end{array}$ & $\begin{array}{c}(2) \\
\text { SRH } \\
\end{array}$ & $\begin{array}{c}(3) \\
\text { Life sat. }\end{array}$ & $\begin{array}{c}(4) \\
\text { Life sat. }\end{array}$ & $\begin{array}{c}(5) \\
\text { Pain } \\
\end{array}$ & $\begin{array}{c}(6) \\
\text { Pain }\end{array}$ & $\begin{array}{c}(7) \\
\text { Depression } \\
\end{array}$ & $\begin{array}{c}(8) \\
\text { Depression } \\
\end{array}$ & $\begin{array}{c}(9) \\
\text { Loneliness } \\
\end{array}$ & $\begin{array}{c}(10) \\
\text { Loneliness }\end{array}$ \\
\hline \multicolumn{11}{|c|}{ Subjective status mobility (ref. about equal) } \\
\hline (Much) lower status & $\begin{array}{l}-.08 \\
(.09)\end{array}$ & $\begin{array}{l}-.10 \\
(.09)\end{array}$ & $\begin{array}{l}.00 \\
(.18)\end{array}$ & $\begin{array}{l}-.03 \\
(.18)\end{array}$ & $\begin{array}{l}.02 \\
(.11)\end{array}$ & $\begin{array}{c}.04 \\
(.10)\end{array}$ & $\begin{array}{l}.05 \\
(.09)\end{array}$ & $\begin{array}{l}.10 \\
(.09)\end{array}$ & $\begin{array}{l}.17 \\
(.09)\end{array}$ & $\begin{array}{l}.19^{*} \\
(.09)\end{array}$ \\
\hline (Much) higher status & $\begin{array}{l}.03 \\
(.07)\end{array}$ & $\begin{array}{l}.03 \\
(.08)\end{array}$ & $\begin{array}{l}.44^{* *} \\
(.13)\end{array}$ & $\begin{array}{l}.44^{* *} \\
(.14)\end{array}$ & $\begin{array}{l}-.10 \\
(.09)\end{array}$ & $\begin{array}{l}-.09 \\
(.09)\end{array}$ & $\begin{array}{l}-.04 \\
(.08)\end{array}$ & $\begin{array}{l}-.07 \\
(.08)\end{array}$ & $\begin{array}{l}.03 \\
(.07)\end{array}$ & $\begin{array}{l}.03 \\
(.07)\end{array}$ \\
\hline \multicolumn{11}{|c|}{ Objective mobility trajectory (ref. stably medium) } \\
\hline Stably low & & $\begin{array}{l}-.25 \\
(.13)\end{array}$ & & $\begin{array}{l}-.33 \\
(.26)\end{array}$ & & $\begin{array}{l}.45^{* *} \\
(.16)\end{array}$ & & $\begin{array}{c}.12 \\
(.15)\end{array}$ & & $\begin{array}{c}.21 \\
(.13)\end{array}$ \\
\hline Low to medium & & $\begin{array}{l}-.22 \\
(.15)\end{array}$ & & $\begin{array}{l}-.01 \\
(.26)\end{array}$ & & $\begin{array}{c}.36^{*} \\
(.17)\end{array}$ & & $\begin{array}{l}.18 \\
(.15)\end{array}$ & & $\begin{array}{c}.13 \\
(.15)\end{array}$ \\
\hline Low to high & & $\begin{array}{l}-.18 \\
(.15)\end{array}$ & & $\begin{array}{l}-.17 \\
(.26)\end{array}$ & & $\begin{array}{l}.17 \\
(.17)\end{array}$ & & $\begin{array}{c}.12 \\
(.15)\end{array}$ & & $\begin{array}{c}.04 \\
(.15)\end{array}$ \\
\hline Medium to low & & $\begin{array}{l}-.26^{*} \\
(.13)\end{array}$ & & $\begin{array}{c}.13 \\
(.23)\end{array}$ & & $\begin{array}{c}.33^{*} \\
(.15)\end{array}$ & & $\begin{array}{c}.02 \\
(.14)\end{array}$ & & $\begin{array}{c}-.05 \\
(.13)\end{array}$ \\
\hline Medium to high & & $\begin{array}{c}.13 \\
(.12)\end{array}$ & & $\begin{array}{c}.39 \\
(.23)\end{array}$ & & $\begin{array}{c}-.17 \\
(.14)\end{array}$ & & $\begin{array}{c}-.09 \\
(.14)\end{array}$ & & $\begin{array}{c}-.10 \\
(.12)\end{array}$ \\
\hline High to low & & $\begin{array}{l}.03 \\
(.15)\end{array}$ & & $\begin{array}{l}-.09 \\
(.38)\end{array}$ & & $\begin{array}{l}-.09 \\
(.21)\end{array}$ & & $\begin{array}{l}-.14 \\
(.21)\end{array}$ & & $\begin{array}{l}.16 \\
(.21)\end{array}$ \\
\hline High to medium & & $\begin{array}{l}.13 \\
(.14)\end{array}$ & & $\begin{array}{c}.39 \\
(.25)\end{array}$ & & $\begin{array}{l}-.07 \\
(.16)\end{array}$ & & $\begin{array}{l}-.27 \\
(.15)\end{array}$ & & $\begin{array}{l}-.10 \\
(.13)\end{array}$ \\
\hline Stably high & & $\begin{array}{l}.29^{* *} \\
(.10)\end{array}$ & & $\begin{array}{l}.56^{* *} \\
(.20)\end{array}$ & & $\begin{array}{c}-.38^{* *} \\
(.12)\end{array}$ & & $\begin{array}{l}-.36^{* *} \\
(.12)\end{array}$ & & $\begin{array}{l}-.19 \\
(.10)\end{array}$ \\
\hline \multicolumn{11}{|l|}{ Control variables } \\
\hline Age & $\begin{array}{c}-.02^{* * *} \\
(.00)\end{array}$ & $\begin{array}{c}-.02^{* * *} \\
(.00)\end{array}$ & $\begin{array}{c}-.00 \\
(.00)\end{array}$ & $\begin{array}{c}.00 \\
(.00)\end{array}$ & $\begin{array}{l}.01^{* * *} \\
(.00)\end{array}$ & $\begin{array}{l}.01^{1+* *} \\
(.00)\end{array}$ & $\begin{array}{c}-.00 \\
(.00)\end{array}$ & $\begin{array}{c}-.00 \\
(.00)\end{array}$ & $\begin{array}{c}.00 \\
(.00)\end{array}$ & $\begin{array}{l}.00 \\
(.00)\end{array}$ \\
\hline Female sex (ref. male) & $\begin{array}{l}-.07 \\
(.07)\end{array}$ & $\begin{array}{l}-.07 \\
(.07)\end{array}$ & $\begin{array}{l}.08 \\
(.13)\end{array}$ & $\begin{array}{l}.08 \\
(.13)\end{array}$ & $\begin{array}{l}.14 \\
(.08)\end{array}$ & $\begin{array}{l}.16^{*} \\
(.08)\end{array}$ & $\begin{array}{l}.23^{* *} \\
(.07)\end{array}$ & $\begin{array}{l}.22^{* *} \\
(.07)\end{array}$ & $\begin{array}{l}.05 \\
(.06)\end{array}$ & $\begin{array}{l}.05 \\
(.07)\end{array}$ \\
\hline \multicolumn{11}{|l|}{ Marital status (ref. married) } \\
\hline Widowed/divorced & $\begin{array}{l}-.07 \\
(.11)\end{array}$ & $\begin{array}{l}-.07 \\
(.10)\end{array}$ & $\begin{array}{c}-.74^{* * *} \\
(.19)\end{array}$ & $\begin{array}{c}-.73^{* * *} \\
(.19)\end{array}$ & $\begin{array}{l}.26^{*} \\
(.12)\end{array}$ & $\begin{array}{l}.25^{*} \\
(.12)\end{array}$ & $\begin{array}{c}.03 \\
(.10)\end{array}$ & $\begin{array}{c}.03 \\
(.10)\end{array}$ & $\begin{array}{l}.57^{*+* *} \\
(.11)\end{array}$ & $\begin{array}{l}.57^{* * * *} \\
(.11)\end{array}$ \\
\hline Never married & $\begin{array}{l}-.12 \\
(.08)\end{array}$ & $\begin{array}{l}-.14 \\
(.08)\end{array}$ & $\begin{array}{l}-.40^{*} \\
(.17)\end{array}$ & $\begin{array}{l}-.42^{*} \\
(.16)\end{array}$ & $\begin{array}{l}.06 \\
(.10)\end{array}$ & $\begin{array}{l}.08 \\
(.10)\end{array}$ & $\begin{array}{l}.20^{*} \\
(.09)\end{array}$ & $\begin{array}{l}.21^{*} \\
(.09)\end{array}$ & $\begin{array}{l}.16^{*} \\
(.08)\end{array}$ & $\begin{array}{l}.17^{*} \\
(.08)\end{array}$ \\
\hline East Germany (ref. West) & $\begin{array}{l}-.12 \\
(.07)\end{array}$ & $\begin{array}{l}-.09 \\
(.07)\end{array}$ & $\begin{array}{c}-.59^{* * *} \\
(.13)\end{array}$ & $\begin{array}{c}-.55^{* * *} \\
(.13)\end{array}$ & $\begin{array}{c}.03 \\
(.08)\end{array}$ & $\begin{array}{l}-.02 \\
(.08)\end{array}$ & $\begin{array}{l}.05 \\
(.07)\end{array}$ & $\begin{array}{c}.02 \\
(.07)\end{array}$ & $\begin{array}{l}-.00 \\
(.06)\end{array}$ & $\begin{array}{l}-.02 \\
(.07)\end{array}$ \\
\hline Constant & $\begin{array}{c}3.79^{* * *} \\
(.13) \\
\end{array}$ & $\begin{array}{c}3.75^{*+*} \\
(.15) \\
\end{array}$ & $\begin{array}{c}7.54^{* * *} \\
(.28) \\
\end{array}$ & $\begin{array}{c}7.29^{* * * *} \\
(.32) \\
\end{array}$ & $\begin{array}{l}.38^{*} \\
(.17) \\
\end{array}$ & $\begin{array}{l}.41^{*} \\
(.19) \\
\end{array}$ & $\begin{array}{c}1.31^{* * *} \\
(.16)\end{array}$ & $\begin{array}{c}1.43^{* * *} \\
(.18) \\
\end{array}$ & $\begin{array}{r}.25 \\
(.13) \\
\end{array}$ & $\begin{array}{c}.31^{*} \\
(.16) \\
\end{array}$ \\
\hline $\mathrm{N}$ & 1,012 & 1,012 & 1,012 & 1,012 & 1,012 & 1,012 & 1,012 & 1,012 & 1,012 & 1,012 \\
\hline Avg. outcome (SD) & $2.55(1.06)$ & $2.55(1.06)$ & $7.27(1.92)$ & $7.27(1.92)$ & $1.05(1.20)$ & $1.05(1.20)$ & $1.31(1.07)$ & $1.31(1.07)$ & $.66(.97)$ & $.66(.97)$ \\
\hline R-squared & .12 & .16 & .06 & .08 & .04 & .10 & .03 & .05 & .06 & .08 \\
\hline
\end{tabular}

Notes: SE's in parentheses. SRH: Self-rated health, Life sat.: Life satisfaction, SD: Standard deviation. ${ }^{*} \mathrm{p}<0.05,{ }^{* *} \mathrm{p}<0.01,{ }^{* * *} \mathrm{p}<0.001$ 
Table A16: Health outcomes regressed on interaction of objective and subjective mobility, OLS regression, weighted analysis, $N=1,012$.

\begin{tabular}{|c|c|c|c|c|c|}
\hline & $\begin{array}{c}(1) \\
\text { SRH }\end{array}$ & $\begin{array}{c}(2) \\
\text { Life sat. }\end{array}$ & $\begin{array}{l}(3) \\
\text { Pain }\end{array}$ & $\begin{array}{c}(4) \\
\text { Depression }\end{array}$ & $\begin{array}{c}(5) \\
\text { Loneliness }\end{array}$ \\
\hline \multicolumn{6}{|l|}{ Subjective status mobility (ref. about equal) } \\
\hline (Much) lower status & $\begin{array}{l}.16 \\
(.12)\end{array}$ & $\begin{array}{c}.33 \\
(.26)\end{array}$ & $\begin{array}{l}-.18 \\
(.14)\end{array}$ & $\begin{array}{l}-.01 \\
(.14)\end{array}$ & $\begin{array}{c}.13 \\
(.13)\end{array}$ \\
\hline (Much) higher status & $\begin{array}{l}.01 \\
(.10)\end{array}$ & $\begin{array}{l}.65^{* * *} \\
(.20)\end{array}$ & $\begin{array}{l}-.03 \\
(.12)\end{array}$ & $\begin{array}{l}.10 \\
(.11)\end{array}$ & $\begin{array}{l}.06 \\
(.10)\end{array}$ \\
\hline \multicolumn{6}{|l|}{ Objective status mobility (ref. immobile) } \\
\hline Downwardly mobile & $\begin{array}{l}.01 \\
(.13)\end{array}$ & $\begin{array}{l}.21 \\
(.23)\end{array}$ & $\begin{array}{c}.18 \\
(.15)\end{array}$ & $\begin{array}{c}.04 \\
(.14)\end{array}$ & $\begin{array}{l}-.03 \\
(.11)\end{array}$ \\
\hline Upwardly mobile & $\begin{array}{l}-.12 \\
(.15)\end{array}$ & $\begin{array}{l}.43 \\
(.27)\end{array}$ & $\begin{array}{l}.08 \\
(.16)\end{array}$ & $\begin{array}{l}.39^{*} \\
(.15)\end{array}$ & $\begin{array}{l}.09 \\
(.14)\end{array}$ \\
\hline \multicolumn{6}{|l|}{ Interaction terms } \\
\hline (Much) lower status $\times$ Downwardly mobile & $\begin{array}{l}-.41^{*} \\
(.19)\end{array}$ & $\begin{array}{l}-.50 \\
(.38)\end{array}$ & $\begin{array}{l}.13 \\
(.23)\end{array}$ & $\begin{array}{l}.16 \\
(.20)\end{array}$ & $\begin{array}{l}.10 \\
(.19)\end{array}$ \\
\hline (Much) lower status $\times$ Upwardly mobile & $\begin{array}{l}-.77^{*} \\
(.34)\end{array}$ & $\begin{array}{l}-.90 \\
(.52)\end{array}$ & $\begin{array}{c}1.27^{* * *} \\
(.33)\end{array}$ & $\begin{array}{c}.32 \\
(.30)\end{array}$ & $\begin{array}{c}.16 \\
(.31)\end{array}$ \\
\hline (Much) higher status $\times$ Downwardly mobile & $\begin{array}{l}-.23 \\
(.22)\end{array}$ & $\begin{array}{l}-.14 \\
(.33)\end{array}$ & $\begin{array}{l}.02 \\
(.25)\end{array}$ & $\begin{array}{l}-.14 \\
(.23)\end{array}$ & $\begin{array}{l}.03 \\
(.20)\end{array}$ \\
\hline (Much) higher status $\times$ Upwardly mobile & $\begin{array}{c}.17 \\
(.18)\end{array}$ & $\begin{array}{l}-.63^{*} \\
(.32)\end{array}$ & $\begin{array}{l}-.17 \\
(.20)\end{array}$ & $\begin{array}{l}-.48^{*} \\
(.19)\end{array}$ & $\begin{array}{l}-.13 \\
(.17)\end{array}$ \\
\hline \multicolumn{6}{|l|}{ Control variables } \\
\hline Age & $\begin{array}{c}-.02^{* * *} \\
(.00)\end{array}$ & $\begin{array}{l}-.00 \\
(.00)\end{array}$ & $\begin{array}{l}.01^{* * *} \\
(.00)\end{array}$ & $\begin{array}{l}-.00 \\
(.00)\end{array}$ & $\begin{array}{l}.00 \\
(.00)\end{array}$ \\
\hline Female sex (ref. male) & $\begin{array}{l}-.06 \\
(.07)\end{array}$ & $\begin{array}{l}.07 \\
(.13)\end{array}$ & $\begin{array}{l}.14 \\
(.08)\end{array}$ & $\begin{array}{l}.21^{* *} \\
(.07)\end{array}$ & $\begin{array}{l}.04 \\
(.07)\end{array}$ \\
\hline \multicolumn{6}{|l|}{ Marital status (ref. married) } \\
\hline Widowed/divorced & $\begin{array}{l}-.09 \\
(.10)\end{array}$ & $\begin{array}{c}-.74^{* * *} \\
(.19)\end{array}$ & $\begin{array}{l}.28^{*} \\
(.12)\end{array}$ & $\begin{array}{c}.05 \\
(.10)\end{array}$ & $\begin{array}{l}.58^{* * *} \\
(.11)\end{array}$ \\
\hline Never married & $\begin{array}{l}-.12 \\
(.08)\end{array}$ & $\begin{array}{l}-.43^{*} \\
(.17)\end{array}$ & $\begin{array}{l}.06 \\
(.10)\end{array}$ & $\begin{array}{l}.19^{*} \\
(.09)\end{array}$ & $\begin{array}{l}.16^{*} \\
(.08)\end{array}$ \\
\hline East Germany (ref. West) & $\begin{array}{l}-.12 \\
(.07)\end{array}$ & $\begin{array}{c}-.59^{* * *} \\
(.13)\end{array}$ & $\begin{array}{c}.04 \\
(.08)\end{array}$ & $\begin{array}{c}.05 \\
(.07)\end{array}$ & $\begin{array}{l}-.00 \\
(.06)\end{array}$ \\
\hline Constant & $\begin{array}{c}3.80^{* * *} \\
(.14)\end{array}$ & $\begin{array}{c}7.42^{* * *} \\
(.32)\end{array}$ & $\begin{array}{c}.33 \\
(.18)\end{array}$ & $\begin{array}{c}1.25^{* * *} \\
(.17)\end{array}$ & $\begin{array}{c}.25 \\
(.15)\end{array}$ \\
\hline$N$ & 1,012 & 1,012 & 1,012 & 1,012 & 1,012 \\
\hline Avg. outcome (SD) & $2.55(1.06)$ & $7.27(1.92)$ & $1.05(1.20)$ & $1.31(1.07)$ & $.66(.97)$ \\
\hline R-squared & .14 & .06 & .07 & .04 & .06 \\
\hline
\end{tabular}

Notes: SE's in parentheses. SRH: Self-rated health, Life sat.: Life satisfaction, SD: Standard deviation. ${ }^{*} \mathrm{p}<0.05,{ }^{* *} \mathrm{p}<0.01,{ }^{* * *} \mathrm{p}<0.001$ 


\section{Ordered logit models}

Our outcome variables are all measured as ordinal variables. It is common to model these variables as linear and using linear models can have advantages when it comes to comparisons of coefficients across models and subgroups (Mood, 2010). Yet, ordered logit models can yield more precise estimates (Agresti, 2010). Tables A17 to A19 show that the results from ordered logit models are substantively similar to those from OLS regression. 
Table A17: Health outcomes regressed on objective mobility trajectories, ordered logit models, logit coefficients, $N=1,012$.

\begin{tabular}{|c|c|c|c|c|c|}
\hline & $\begin{array}{c}(1) \\
\mathrm{SRH}\end{array}$ & $\begin{array}{c}(2) \\
\text { Life sat. }\end{array}$ & $\begin{array}{c}(3) \\
\text { Pain }\end{array}$ & $\begin{array}{c}(4) \\
\text { Depression }\end{array}$ & $\begin{array}{c}(5) \\
\text { Loneliness }\end{array}$ \\
\hline \multicolumn{6}{|c|}{ Objective mobility trajectory (ref. stably medium) } \\
\hline Stably low & $\begin{array}{l}-.36 \\
(.22)\end{array}$ & $\begin{array}{l}-.37 \\
(.22)\end{array}$ & $\begin{array}{l}.69^{* *} \\
(.22)\end{array}$ & $\begin{array}{l}.31 \\
(.23)\end{array}$ & $\begin{array}{c}.39 \\
(.24)\end{array}$ \\
\hline Low to medium & $\begin{array}{l}-.36 \\
(.26)\end{array}$ & $\begin{array}{l}-.08 \\
(.25)\end{array}$ & $\begin{array}{l}.57^{*} \\
(.25)\end{array}$ & $\begin{array}{l}.42 \\
(.25)\end{array}$ & $\begin{array}{l}.29 \\
(.28)\end{array}$ \\
\hline Low to high & $\begin{array}{l}-.26 \\
(.27)\end{array}$ & $\begin{array}{l}-.11 \\
(.26)\end{array}$ & $\begin{array}{c}.28 \\
(.27)\end{array}$ & $\begin{array}{l}.16 \\
(.27)\end{array}$ & $\begin{array}{l}.11 \\
(.30)\end{array}$ \\
\hline Medium to low & $\begin{array}{l}-.50^{*} \\
(.22)\end{array}$ & $\begin{array}{l}-.07 \\
(.21)\end{array}$ & $\begin{array}{l}.56^{*} \\
(.22)\end{array}$ & $\begin{array}{l}.19 \\
(.22)\end{array}$ & $\begin{array}{l}-.08 \\
(.25)\end{array}$ \\
\hline Medium to high & $\begin{array}{l}.29 \\
(.22)\end{array}$ & $\begin{array}{l}.53^{*} \\
(.21)\end{array}$ & $\begin{array}{l}-.27 \\
(.22)\end{array}$ & $\begin{array}{l}-.09 \\
(.22)\end{array}$ & $\begin{array}{l}-.14 \\
(.25)\end{array}$ \\
\hline High to low & $\begin{array}{l}-.10 \\
(.30)\end{array}$ & $\begin{array}{l}-.10 \\
(.31)\end{array}$ & $\begin{array}{c}.00 \\
(.32)\end{array}$ & $\begin{array}{l}-.08 \\
(.31)\end{array}$ & $\begin{array}{l}.39 \\
(.34)\end{array}$ \\
\hline High to medium & $\begin{array}{c}.22 \\
(.24)\end{array}$ & $\begin{array}{c}.28 \\
(.23)\end{array}$ & $\begin{array}{c}.08 \\
(.24)\end{array}$ & $\begin{array}{l}-.32 \\
(.24)\end{array}$ & $\begin{array}{c}.00 \\
(.26)\end{array}$ \\
\hline Stably high & $\begin{array}{l}.53^{* *} \\
(.19)\end{array}$ & $\begin{array}{l}.51^{* *} \\
(.19)\end{array}$ & $\begin{array}{c}-.55^{* *} \\
(.20)\end{array}$ & $\begin{array}{c}-.51^{* *} \\
(.19)\end{array}$ & $\begin{array}{l}-.23 \\
(.22)\end{array}$ \\
\hline \multicolumn{6}{|l|}{ Control variables } \\
\hline Age & $\begin{array}{c}-.04^{* * *} \\
(.00)\end{array}$ & $\begin{array}{l}-.00 \\
(.00)\end{array}$ & $\begin{array}{l}.02^{* * *} \\
(.00)\end{array}$ & $\begin{array}{l}-.01^{*} \\
(.00)\end{array}$ & $\begin{array}{l}.00 \\
(.00)\end{array}$ \\
\hline Female sex (ref. male) & $\begin{array}{l}-.15 \\
(.12)\end{array}$ & $\begin{array}{c}.06 \\
(.11)\end{array}$ & $\begin{array}{l}.24^{*} \\
(.12)\end{array}$ & $\begin{array}{l}.42^{* * *} \\
(.12)\end{array}$ & $\begin{array}{c}.14 \\
(.13)\end{array}$ \\
\hline \multicolumn{6}{|l|}{ Marital status (ref. married) } \\
\hline Widowed/divorced & $\begin{array}{l}-.05 \\
(.17)\end{array}$ & $\begin{array}{c}-.60^{* * *} \\
(.17)\end{array}$ & $\begin{array}{c}.31 \\
(.17)\end{array}$ & $\begin{array}{c}.08 \\
(.17)\end{array}$ & $\begin{array}{c}1.06^{* * *} \\
(.18)\end{array}$ \\
\hline Never married & $\begin{array}{l}-.21 \\
(.16)\end{array}$ & $\begin{array}{c}-.43^{* *} \\
(.15)\end{array}$ & $\begin{array}{c}.06 \\
(.16)\end{array}$ & $\begin{array}{l}.30 \\
(.16)\end{array}$ & $\begin{array}{l}.44^{*} \\
(.18)\end{array}$ \\
\hline East Germany (ref. West) & $\begin{array}{l}-.17 \\
(.13)\end{array}$ & $\begin{array}{c}-.68^{* * *} \\
(.12)\end{array}$ & $\begin{array}{l}-.01 \\
(.13)\end{array}$ & $\begin{array}{c}.01 \\
(.13)\end{array}$ & $\begin{array}{l}-.01 \\
(.14)\end{array}$ \\
\hline$N$ & 1,012 & 1,012 & 1,012 & 1,012 & 1,012 \\
\hline
\end{tabular}

Notes: SE's in parentheses. Cutpoints not shown. SRH: Self-rated health, Life sat.: Life satisfaction, SD: Standard deviation. ${ }^{*} \mathrm{p}<0.05,{ }^{* *} \mathrm{p}<0.01,{ }^{* * *} \mathrm{p}<0.001$ 
Table A18: Health outcomes regressed on subjective mobility and objective mobility trajectories, ordered logit models, logit coefficients, $N=1,012$.

\begin{tabular}{|c|c|c|c|c|c|c|c|c|c|c|}
\hline & $\begin{array}{c}(1) \\
\text { SRH }\end{array}$ & $\begin{array}{l}(2) \\
\text { SRH }\end{array}$ & $\begin{array}{c}\text { (3) } \\
\text { Life sat. }\end{array}$ & $\begin{array}{c}(4) \\
\text { Life sat. }\end{array}$ & $\begin{array}{l}(5) \\
\text { Pain }\end{array}$ & $\begin{array}{l}(6) \\
\text { Pain }\end{array}$ & $\begin{array}{c}(7) \\
\text { Depression }\end{array}$ & $\begin{array}{c}(8) \\
\text { Depression }\end{array}$ & $\begin{array}{c}(9) \\
\text { Loneliness }\end{array}$ & $\begin{array}{c}(10) \\
\text { Loneliness }\end{array}$ \\
\hline \multicolumn{11}{|c|}{ Subjective status mobility (ref. about equal) } \\
\hline (Much) lower status & $\begin{array}{l}-.14 \\
(.16)\end{array}$ & $\begin{array}{l}-.20 \\
(.16)\end{array}$ & $\begin{array}{l}-.02 \\
(.15)\end{array}$ & $\begin{array}{l}-.08 \\
(.16)\end{array}$ & $\begin{array}{l}.08 \\
(.16)\end{array}$ & $\begin{array}{l}.12 \\
(.16)\end{array}$ & $\begin{array}{l}.05 \\
(.15)\end{array}$ & $\begin{array}{l}.12 \\
(.16)\end{array}$ & $\begin{array}{l}.35^{*} \\
(.17)\end{array}$ & $\begin{array}{l}.37^{*} \\
(.17)\end{array}$ \\
\hline (Much) higher status & $\begin{array}{l}.06 \\
(.13)\end{array}$ & $\begin{array}{l}.05 \\
(.14)\end{array}$ & $\begin{array}{l}.30^{*} \\
(.13)\end{array}$ & $\begin{array}{l}.30^{*} \\
(.13)\end{array}$ & $\begin{array}{l}-.11 \\
(.13)\end{array}$ & $\begin{array}{l}-.10 \\
(.14)\end{array}$ & $\begin{array}{l}-.12 \\
(.13)\end{array}$ & $\begin{array}{l}-.17 \\
(.14)\end{array}$ & $\begin{array}{l}.13 \\
(.15)\end{array}$ & $\begin{array}{l}.12 \\
(.16)\end{array}$ \\
\hline \multicolumn{11}{|c|}{ Objective mobility trajectory ( $r e f$. stably medium) } \\
\hline Stably low & & $\begin{array}{l}-.35 \\
(.22)\end{array}$ & & $\begin{array}{l}-.36 \\
(.22)\end{array}$ & & $\begin{array}{l}.68^{* *} \\
(.22)\end{array}$ & & $\begin{array}{l}.29 \\
(.23)\end{array}$ & & $\begin{array}{l}.37 \\
(.24)\end{array}$ \\
\hline Low to medium & & $\begin{array}{l}-.37 \\
(.26)\end{array}$ & & $\begin{array}{l}-.11 \\
(.25)\end{array}$ & & $\begin{array}{l}.56^{*} \\
(.25)\end{array}$ & & $\begin{array}{l}.42 \\
(.25)\end{array}$ & & $\begin{array}{l}.29 \\
(.28)\end{array}$ \\
\hline Low to high & & $\begin{array}{l}-.28 \\
(.28)\end{array}$ & & $\begin{array}{l}-.19 \\
(.26)\end{array}$ & & $\begin{array}{l}.31 \\
(.27)\end{array}$ & & $\begin{array}{l}.22 \\
(.27)\end{array}$ & & $\begin{array}{l}.10 \\
(.30)\end{array}$ \\
\hline Medium to low & & $\begin{array}{l}-.45^{*} \\
(.22)\end{array}$ & & $\begin{array}{l}-.00 \\
(.21)\end{array}$ & & $\begin{array}{l}.52^{*} \\
(.22)\end{array}$ & & $\begin{array}{l}.13 \\
(.22)\end{array}$ & & $\begin{array}{l}-.12 \\
(.25)\end{array}$ \\
\hline Medium to high & & $\begin{array}{l}.25 \\
(.22)\end{array}$ & & $\begin{array}{l}.45^{*} \\
(.22)\end{array}$ & & $\begin{array}{l}-.23 \\
(.23)\end{array}$ & & $\begin{array}{l}-.03 \\
(.22)\end{array}$ & & $\begin{array}{l}-.12 \\
(.25)\end{array}$ \\
\hline High to low & & $\begin{array}{l}-.01 \\
(.30)\end{array}$ & & $\begin{array}{l}.04 \\
(.32)\end{array}$ & & $\begin{array}{l}-.08 \\
(.33)\end{array}$ & & $\begin{array}{l}-.18 \\
(.32)\end{array}$ & & $\begin{array}{l}.32 \\
(.35)\end{array}$ \\
\hline High to medium & & $\begin{array}{l}.31 \\
(.25)\end{array}$ & & $\begin{array}{l}.39 \\
(.24)\end{array}$ & & $\begin{array}{l}-.00 \\
(.25)\end{array}$ & & $\begin{array}{l}-.40 \\
(.25)\end{array}$ & & $\begin{array}{l}-.09 \\
(.27)\end{array}$ \\
\hline Stably high & & $\begin{array}{l}.57^{* *} \\
(.19)\end{array}$ & & $\begin{array}{l}.55^{* *} \\
(.19)\end{array}$ & & $\begin{array}{l}-.59^{* *} \\
(.20)\end{array}$ & & $\begin{array}{c}-.54^{* *} \\
(.19)\end{array}$ & & $\begin{array}{l}-.27 \\
(.22)\end{array}$ \\
\hline \multicolumn{11}{|l|}{ Control variables } \\
\hline Age & $\begin{array}{c}-.04^{* * *} \\
(.00)\end{array}$ & $\begin{array}{c}-.04^{* * *} \\
(.00)\end{array}$ & $\begin{array}{l}-.00 \\
(.00)\end{array}$ & $\begin{array}{l}-.00 \\
(.00)\end{array}$ & $\begin{array}{l}.02^{* * *} \\
(.00)\end{array}$ & $\begin{array}{l}.02^{* * *} \\
(.00)\end{array}$ & $\begin{array}{l}-.01^{*} \\
(.00)\end{array}$ & $\begin{array}{l}-.01^{*} \\
(.00)\end{array}$ & $\begin{array}{l}.00 \\
(.00)\end{array}$ & $\begin{array}{l}.00 \\
(.00)\end{array}$ \\
\hline Female sex (ref. male) & $\begin{array}{l}-.10 \\
(.12)\end{array}$ & $\begin{array}{l}-.11 \\
(.12)\end{array}$ & $\begin{array}{l}.14 \\
(.12)\end{array}$ & $\begin{array}{l}.13 \\
(.12)\end{array}$ & $\begin{array}{l}.18 \\
(.12)\end{array}$ & $\begin{array}{l}.21 \\
(.12)\end{array}$ & $\begin{array}{l}.39^{* * *} \\
(.12)\end{array}$ & $\begin{array}{l}.37^{* *} \\
(.12)\end{array}$ & $\begin{array}{l}.09 \\
(.13)\end{array}$ & $\begin{array}{l}.10 \\
(.13)\end{array}$ \\
\hline \multicolumn{11}{|l|}{ Marital status (ref. married) } \\
\hline Widowed/divorced & $\begin{array}{l}-.05 \\
(.17)\end{array}$ & $\begin{array}{l}-.04 \\
(.17)\end{array}$ & $\begin{array}{c}-.61^{* * *} \\
(.17)\end{array}$ & $\begin{array}{c}-.59^{* * *} \\
(.17)\end{array}$ & $\begin{array}{c}.30 \\
(.17)\end{array}$ & $\begin{array}{c}.30 \\
(.17)\end{array}$ & $\begin{array}{l}.05 \\
(.17)\end{array}$ & $\begin{array}{l}.08 \\
(.17)\end{array}$ & $\begin{array}{c}1.04^{* * *} \\
(.18)\end{array}$ & $\begin{array}{c}1.04^{* * *} \\
(.18)\end{array}$ \\
\hline Never married & $\begin{array}{l}-.19 \\
(.16)\end{array}$ & $\begin{array}{l}-.20 \\
(.16)\end{array}$ & $\begin{array}{l}-.39^{*} \\
(.15)\end{array}$ & $\begin{array}{l}-.42^{* *} \\
(.15)\end{array}$ & $\begin{array}{l}.07 \\
(.16)\end{array}$ & $\begin{array}{c}.05 \\
(.16)\end{array}$ & $\begin{array}{l}.28 \\
(.16)\end{array}$ & $\begin{array}{l}.30 \\
(.16)\end{array}$ & $\begin{array}{l}.41^{*} \\
(.17)\end{array}$ & $\begin{array}{l}.42^{*} \\
(.18)\end{array}$ \\
\hline East Germany (ref. West) & $\begin{array}{l}-.24 \\
(.12)\end{array}$ & $\begin{array}{l}-.17 \\
(.13)\end{array}$ & $\begin{array}{c}-.70^{* * *} \\
(.12)\end{array}$ & $\begin{array}{c}-.66^{* * *} \\
(.12)\end{array}$ & $\begin{array}{l}.07 \\
(.13)\end{array}$ & $\begin{array}{l}-.02 \\
(.13)\end{array}$ & $\begin{array}{l}.07 \\
(.12)\end{array}$ & $\begin{array}{l}.00 \\
(.13)\end{array}$ & $\begin{array}{c}.03 \\
(.14)\end{array}$ & $\begin{array}{l}.01 \\
(.14)\end{array}$ \\
\hline$N$ & 1,012 & 1,012 & 1,012 & 1,012 & 1,012 & 1,012 & 1,012 & 1,012 & 1,012 & 1,012 \\
\hline
\end{tabular}

Notes: SE's in parentheses. Cutpoints not shown. SRH: Self-rated health, Life sat.: Life satisfaction, SD: Standard deviation. ${ }^{*} \mathrm{p}<0.05,{ }^{* *} \mathrm{p}<0.01,{ }^{* * *} \mathrm{p}<0.001$ 
Table A19: Health outcomes regressed on interaction of objective and subjective mobility, ordered logit models, logit coefficients, $N=1,012$.

\begin{tabular}{|c|c|c|c|c|c|}
\hline & $\begin{array}{c}(1) \\
\mathrm{SRH}\end{array}$ & $\begin{array}{c}(2) \\
\text { Life sat. }\end{array}$ & $\begin{array}{c}(3) \\
\text { Pain }\end{array}$ & $\begin{array}{c}(4) \\
\text { Depression }\end{array}$ & $\begin{array}{c}(5) \\
\text { Loneliness }\end{array}$ \\
\hline \multicolumn{6}{|l|}{ Subjective status mobility (ref. about equal) } \\
\hline \multirow[t]{2}{*}{ (Much) lower status } & .23 & .24 & -.15 & -.00 & .34 \\
\hline & $(.23)$ & $(.22)$ & $(.24)$ & $(.22)$ & $(.25)$ \\
\hline \multirow[t]{2}{*}{ (Much) higher status } & -.01 & $.47^{* *}$ & .07 & .13 & .17 \\
\hline & $(.19)$ & $(.18)$ & $(.19)$ & $(.19)$ & $(.21)$ \\
\hline \multicolumn{6}{|l|}{ Objective status mobility (ref. immobile) } \\
\hline \multirow[t]{2}{*}{ Downwardly mobile } & -.04 & .13 & .40 & .10 & -.02 \\
\hline & $(.22)$ & $(.22)$ & $(.22)$ & $(.22)$ & $(.25)$ \\
\hline \multirow[t]{2}{*}{ Upwardly mobile } & -.27 & .34 & .24 & $.80^{* * *}$ & .16 \\
\hline & $(.25)$ & $(.24)$ & $(.25)$ & $(.24)$ & $(.28)$ \\
\hline \multicolumn{6}{|l|}{ Interaction terms } \\
\hline \multirow[t]{2}{*}{ (Much) lower status $\times$ Downwardly mobile } & $-.67^{*}$ & -.40 & .04 & .25 & .07 \\
\hline & $(.34)$ & $(.33)$ & $(.34)$ & $(.33)$ & $(.37)$ \\
\hline \multirow[t]{2}{*}{ (Much) lower status $\times$ Upwardly mobile } & $-1.31^{*}$ & -.71 & $1.69^{* * *}$ & .16 & .07 \\
\hline & $(.54)$ & $(.49)$ & $(.50)$ & $(.49)$ & $(.55)$ \\
\hline \multirow[t]{2}{*}{ (Much) higher status $\times$ Downwardly mobile } & -.28 & -.10 & -.10 & -.24 & -.04 \\
\hline & $(.37)$ & $(.35)$ & $(.37)$ & $(.37)$ & $(.42)$ \\
\hline \multirow[t]{2}{*}{ (Much) higher status $\times$ Upwardly mobile } & .37 & -.51 & -.38 & $-.91^{* *}$ & -.18 \\
\hline & $(.31)$ & $(.31)$ & $(.32)$ & $(.31)$ & $(.35)$ \\
\hline \multicolumn{6}{|l|}{ Control variables } \\
\hline \multirow[t]{2}{*}{ Age } & $-.04^{* * *}$ & -.00 & $.02^{* * *}$ & $-.01^{*}$ & .00 \\
\hline & $(.00)$ & $(.00)$ & $(.00)$ & $(.00)$ & $(.00)$ \\
\hline \multirow[t]{2}{*}{ Female sex (ref. male) } & -.09 & .12 & .18 & $.35^{* *}$ & .07 \\
\hline & $(.12)$ & $(.12)$ & $(.12)$ & $(.12)$ & $(.13)$ \\
\hline \multicolumn{6}{|l|}{ Marital status (ref. married) } \\
\hline \multirow[t]{2}{*}{ Widowed/divorced } & -.08 & $-.61^{* * *}$ & $.33^{*}$ & .09 & $1.05^{* * *}$ \\
\hline & $(.17)$ & $(.17)$ & $(.17)$ & $(.17)$ & $(.18)$ \\
\hline \multirow[t]{2}{*}{ Never married } & -.16 & $-.41^{* *}$ & .06 & .27 & $.41^{*}$ \\
\hline & $(.16)$ & $(.15)$ & $(.16)$ & $(.16)$ & $(.18)$ \\
\hline \multirow[t]{2}{*}{ East Germany (ref. West) } & $-.25^{*}$ & $-.70^{* * *}$ & .07 & .07 & .04 \\
\hline & $(.12)$ & $(.12)$ & $(.13)$ & $(.12)$ & $(.14)$ \\
\hline$N$ & 1,012 & 1,012 & 1,012 & 1,012 & 1,012 \\
\hline
\end{tabular}

Notes: SE's in parentheses. Cutpoints not shown. SRH: Self-rated health, Life sat.: Life satisfaction, SD: Standard deviation. ${ }^{*} \mathrm{p}<0.05,{ }^{* *} \mathrm{p}<0.01,{ }^{* * *} \mathrm{p}<0.001$ 